INTER NATIONAL MONETARY FUND
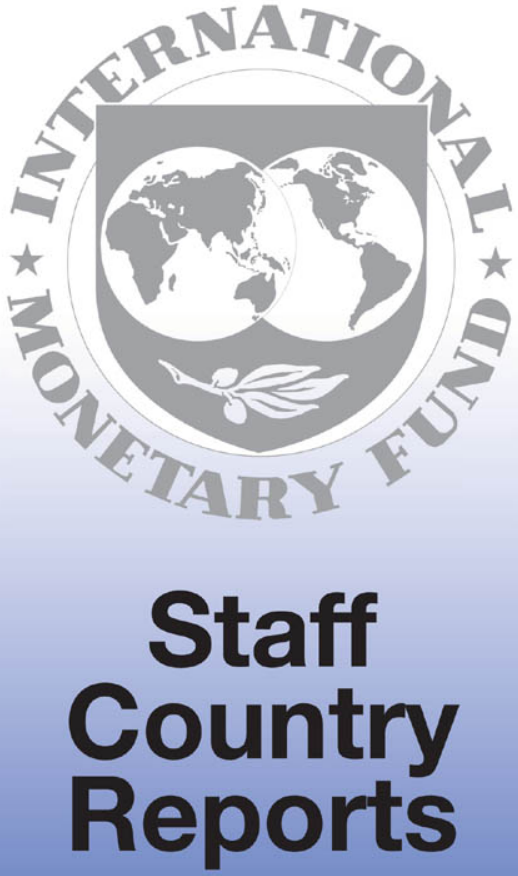


\title{
Burkina Faso: Fourth Review Under the Poverty Reduction and Growth Facility and the Third Annual Program-Staff Report and News Briefs on Executive Board Discussion.
}

Under Article IV of the IMF's Articles of Agreement, the IMF holds bilateral discussions with members, usually every year. In the context of a combined discussion of the Fourth Review under the Poverty Reduction and Growth Facility and the Third Annual Program, the following documents have been released and are included in this package:

- the staff report for the Fourth Review under the Poverty Reduction and Growth Facility and the Third Annual Program prepared by a staff team of the IMF, following discussions that ended on September 19,2001, with the officials of Burkina Faso on economic developments and policies. Based on information available at the time of these discussions, the staff report was completed on November 5, 2001. The views expressed in the staff report are those of the staff tcam and do not necessarily reflect the views of the Executive Board of the IMF;

- the News Briefs summarizing the views of the Executive Board as expressed during the November 30, 2001 Executive Board discussion of the staff report that concluded the Fourth Review under the Poverty Reduction and Growth Facility and the Third Annual Program.

The document(s) listed below have been or will be separately released:

Letter of Intent*

Memorandum of Economic and Financial Policies*

Technical Memorandum of Understanding*

Poverty Reduction Stratcgy Paper-Progress Report-July 2000 - June 2001

Poverty Reduction Strategy Paper-Progress Report-July 2000 - June 2001-Joint Staff Assessment

*May also be included in Staff Report.

The policy of publication of staff reports and other documents by the IMF allows for the deletion of market-sensitive information.

To assist the IMF in evaluating the publication policy, reader comments are invited and may be sent by e-mail to Publicationpolicy@imf.org.

\author{
Copies of this report are available to the public from \\ International Monetary Fund - Publication Services \\ 700 19th Street, N.W. - Washington, D.C. 20431 \\ Telephone; (202) 6237430 - Telefax: (202) 6237201 \\ E-mail: publications@imf.org • Internet: http://www.imf.org \\ Price: $\$ 15.00$ a copy \\ International Monetary Fund \\ Washington, D.C.
}




\title{
INTERNATIONAL MONETARY FUND
}

\author{
BURKINA FASO
}

\section{Fourth Review Under the Poverty Reduction and Growth Facility and the Third Anmual Program \\ Prepared by the African Department \\ (In consultation with Fiscal, Legal, Monetary and Exchange Affairs, Policy Development Review, Statistics, and Treasurer's Departments) \\ Approved by Amor Tahari and Jesús Seade}

November 5, 2001

Contents

Page

Executive Summary ......................................................................................................

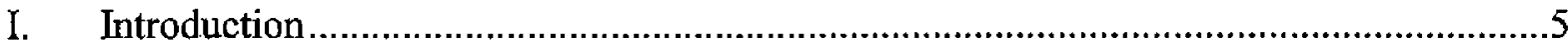

II. Recent Economic Performance ………................................................................

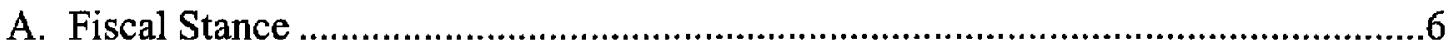

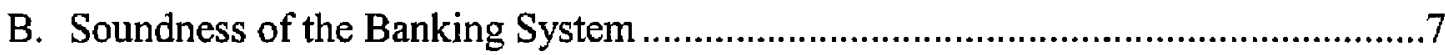

C. Structural Reforms ...........................................................................................

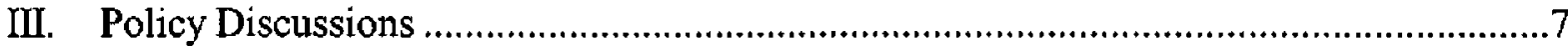

A. Economic Prospects ..................................................................................

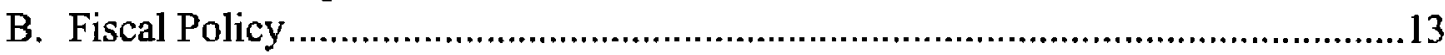

C. Monetary and Banking Policy.............................................................................14

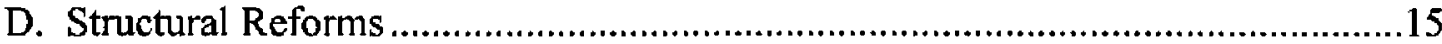

E. Regional Integration...................................................................................17

F. Program Monitoring...............................................................................17

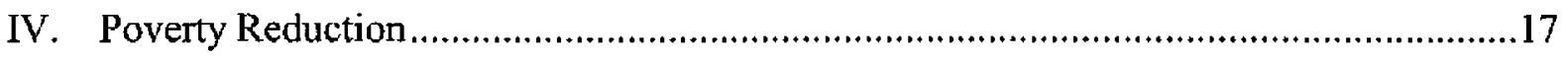

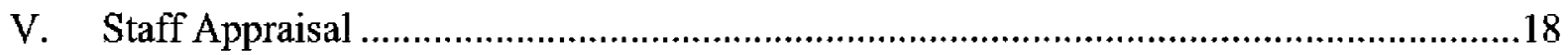


Boxes

1. The Cotton Sector in Burkina Faso: Reforms, Social Impact, and Outlook.................9

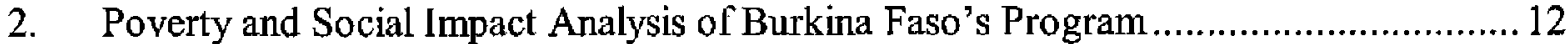

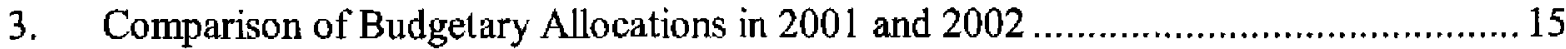

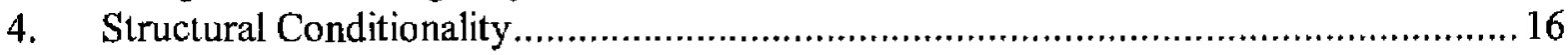

\section{Figures}

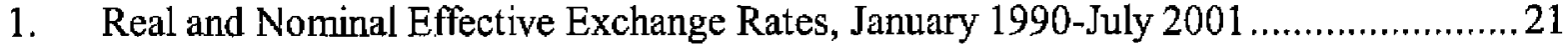

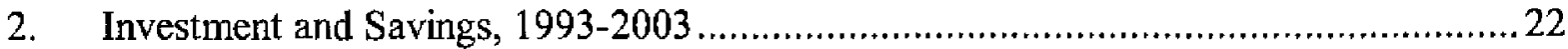

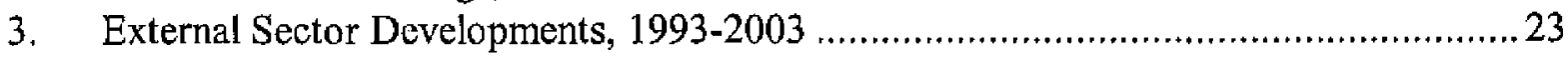

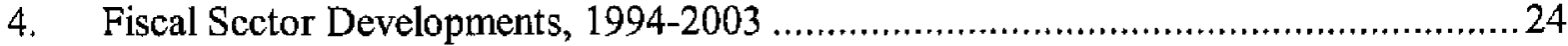

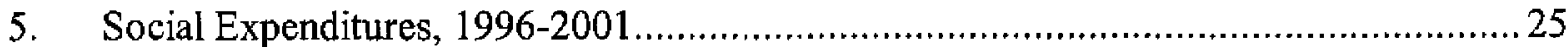

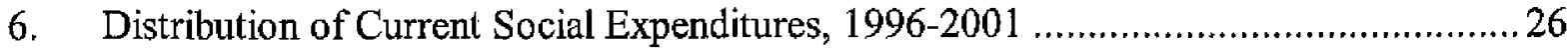

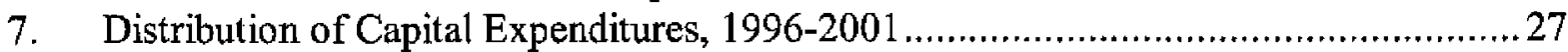

8. Primary School Enrollment Ratio, 1996/97 - 2003/04 ..................................... 28

9. Coverage of Basic Education, 1996/97 - 2003/04 .............................................29

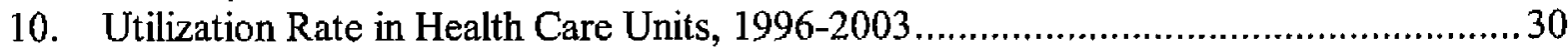

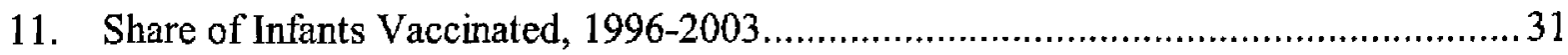

Tables

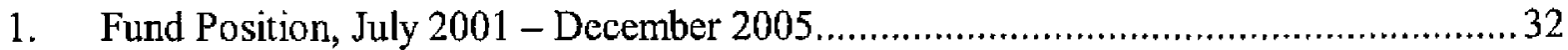

2. Selected Economic and Financial Indicators, 1999-2005 .......................................33

3. Consolidated Operations of the Central Government, 1999-2005 ........................ 34

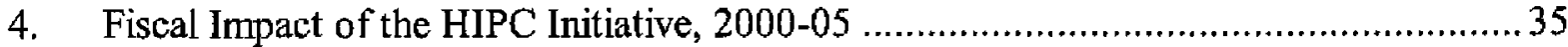

5. Expenditures Financed by HIPC Initiative Resources, 2000-02 .............................36

6. Budgetary Expcnditure in Social Sectors (Including HIPC Initiative Resources),

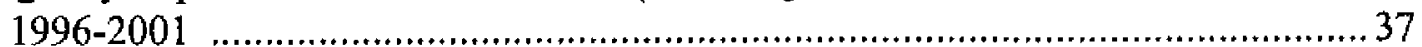

7. $\quad$ Balance of Payments, 1999-2005 ............................................................ 38

8. Tracking Dclivery of HIPC Initiative Assistance - Original and Enhanced

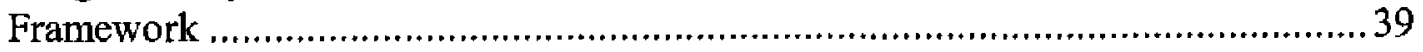

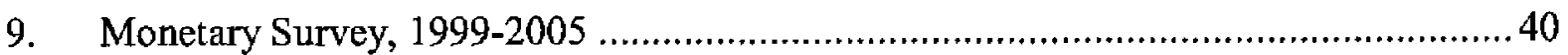

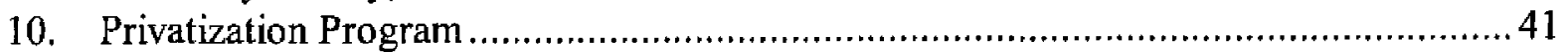

11. Compliance with Regional Integration Under the WAEMU, 1997-2005 ..................43

12. Income and Social Indicators ................................................................... 44

Appendices

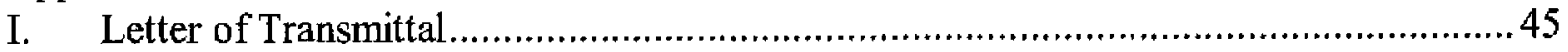

Attachment I: Memorandum on Economic and Financial Policies for 2001/02 _.....47

Attachment II: Technical Memorandum of Understanding ..............................60

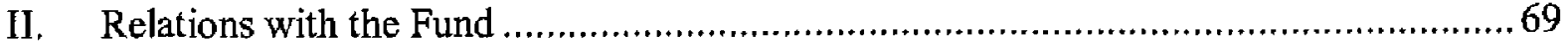

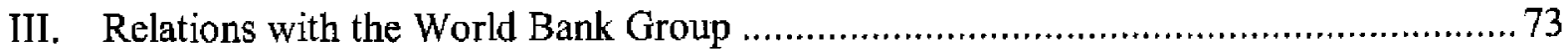

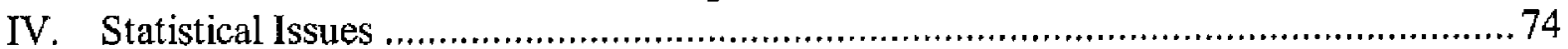

V. Tentative Work Program Under the PRGF Arrangement, 2000-02 2......................78

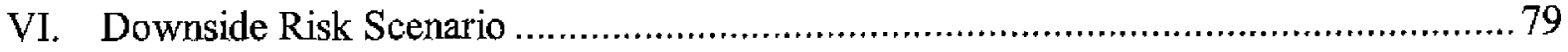




\section{EXECUTIVE SUMMARY}

\section{Background}

- Burkina Faso's head of state, Mr, Blajse Compaoré, came to power in October 1987. He was elected President in December 1991 and reelected in multiparty elections in November 1998. A new multiparty government was formed in November 2000 . The Prime Minister, and also Minister of Economy and Finance, is Mr. Paramanga E. Yonli, seconded by a Deputy Minister of Economy and Finance, Mr. Jean-Baptiste Compaoré. Legislative elections are scheduled to take place in April-May 2002.

- The program remains broadly on track. The economic downturn of 2000 trailed into the first half of 2001. Because of cereals shortages, prices rose by nearly 5 percent year-on-year in the lirst nine months of 2001. At end-June 2001, the overall fiscal deficit was somewhat larger than targeted as a revenue shortfall was only partially offset by curtailments in public outlays. External assistance was also lower than anticipated. To adjust for these shortfalls, the authorities issued a six-month treasury bill, while observing the end-June performance criterion on net bank credit to the government.

- All of the end-June and end-September 2001 quantitative and structural performance criteria, benchmarks, and indicators were met, except for the indicator on current government revenue. After achieving the policy reform conditions for the floating completion point under the enhanced HIPC Initiative in March 2001, the authorities finalized preparations for the completion point. Also, the authoritics prepared a progress report for the first-year implementation of the PRSP after extensive consultations with civil society and devclopment partners.

\section{Prospects for end-2001 and 2002}

- Real GDP for 2001 is projected to grow by 6.2 percent on the basis of a rebound in agricultural output. The expected bumper cotton crop will significantly reduce rural poverty. With the abundant availability of cereals, inflation should decline to about 3 percent. Real GDP growth is expected to reach 5.8 percent in 2002 , with inflation remaining low. However, if the downfall in international cotton prices continues, there is a serious concern that producer prices would have to be cut, and that growth would need to be revised downward. The external current account deficit (excluding grants) is cxpected to narrow slightly to 17.7 percent of GDP in 2001, and to narrow further in 2002 to 14.6 percent of GDP. A downside risk scenario predicated on lower agricultural output and workers' remittances results in an annual real GDP growth of about 4.5 percent for the medium term.

- Despite the revenue shortfall, the authorities intend to achieve the program objective of an overall fiscal deficit of about 5 percent of GDP in 2001. Tax revenue, projected at 14 percent of GDP, will be secured through an increase in excise taxes on petroleum products and some administration measures. While the wage bill was revised upward, mainly to accommodatc hiring in the social sectors, other current cxpenditure will be cut by more than 1 percent of GDP compared with program estimates. Social outlays will continue their upward trend.

The 2002 budget, which includes HIPC Initiative related resources equivalent to 1.3 percent of GDP, is in line with the original program. The overall fiscal deficit is targeted 
at 4 percent of GDP, with tax revenue rising to 14.5 percent of GDP and current expenditure remaining subdued. Resources available for poverty reduction have been increased.

- The structural reform program will focus on further improvement of public finance management, the strengthening of judiciary reform and good governance, the pursuit of the privatization program, and policies to promote the private sector promotion policies.

- The government is pursuing its poverty reduction strategy in line with the PRSP, and there has been noticeable progress in social outcomes.

\section{Staff appraisal}

- Sustaining the medium-term growth rate of about $5 \frac{1}{2}$ percent per annum compatible with the poverty reduction objectives will require good weather conditions, continued fiscal consolidation, the deepening of structural reforms, the strengthening of governance, and further progress in human resources development.

- A major risk is the collapse of cotton prices. While, in an electoral context, the authorities are reluctant to reduce the produccr price below its current level because of the need to preserve the income of the rural sector, the utmost caution will have to be exercised to preserve the equilibrium of the sector. A cut in the producer price might be needed, impairing the growth objectives.

- On the fiscal front, the response to the revenue shortfall in 2001 was appropriate. The increase in the excise tax on petroleum products and the timely curtailment in current expenditure, while preserving social outlays, will allow the government to meet its overall deficit and domestic debtreduction targets while achieving its poverty reduction objectives. The need for an upward revision in the salary base was nccessary to accommodate new hiring in the social sectors and to correct the antiquated indemnities grid, but the linkage of the increase to retroactive wage adjustments should not be repeated. In the future, the authorities should endeavor to strictly control the wage bill.

- The staff commends the authorities for vigorously pursuing the poverty reduction objectives embedded in the PRSP and for having prepared the first annual progress report. However, further efforts are needed to improve the planning, execution, and tracking of the strategy, notably by accelerating the commitment of available resources and energizing the monitoring unit in charge of tracking. 


\section{INTRODUCTION}

1. Burkina Faso's three-year arrangement under the Poverty Reduction and Growth Facility (PRGF) for an amount equivalent to SDR 39.12 million (65 percent of quota) was approved on September 10,1999. The third review of the PRGF arrangement together with the 2001 Article IV consultation, took place on July 2, 2001. . To date, four disbursements totaling the equivalent to SDR 22.36 million have been made. In July 2000 , the Fund and World Bank Boards respectively decided that Burkina Faso had fulfilled the conditions for reaching the completion point under the original Initiative for Heavily Indebted Poor Countries (HIPC) Initiative and the decision point under the enhanced Initiative, and that the poverty reduction strategy paper (PRSP) included a thorough analysis of poverty in Burkina Faso and a clear strategy to alleviate it. The completion point under the enhanced HIPC Initiative was not considered at the July 2001 Board meeting because the new government requested additional time to demonstrate progress under their poverty reduclion strategy.

2. In concluding the 2001 Article IV consultation in July 2001, Executive Directors noted that, despite the 2000 economic slowdown caused by exogenous factors, the government had continued to implement sound macroeconomic policies and active structural reforms. They stressed the need to pursue fiscal consolidation, notably through a strict limitation of nonessential outlays and an increase in tax revenue, in order to free resources for investment and social sectors. Directors also encouraged the aulhorities to improve cash-flow management at the treasury

3. President Compaoré was reelected in multiparty clections in November 1998. Following two years of social tensions, the relaxation of the political climate, which began in November 2000 when a new government was formed with the participation of several opposition parties, continues to prevail. Legislative elections are scheduled to take place in April-May 2002 and are considered as a crucial step in the democratization process.

4. The discussions for the fourth review and the third annual program under the PRGF arrangement took place in Ouagadougou during September 4-19, 2001. ${ }^{2}$ The attached memorandum on economic and financial policies (MEFP), (Appendix I Attachment I), reviews

${ }^{1}(\mathrm{EBS} / 01 / 84,6 / 13 / 01)$.

${ }^{2}$ The Burkinabè representatives included Mr. Jean-Baptiste Compaoré, Deputy Minister of Economy and Finance, and Mr. Célestin Zallé, the National Director of the Central Bank of West African States (BCEAO). The mission also met the Prime Minister and Minister of Economy and Finance, Mr, Paramanga E.Yonli. The staff team comprised Mr, van den Boogaerde (head), Mr. Caupin, Mr. Atsou-Dzini, Mr. Bouscharain, and Ms. Jouanin, Assistant (all AFR). The Resident Representative, Mr. Franco, participated in the mission, which was also assisted by the Research Assistant of the resident mission, Mr. Ouattara. The mission also worked closely with the staff of the World Bank's parallel mission. 
economic developments through June 2001 and outlines the economic measures to be implemented for the remainder of 2001 and in 2002. It indicates that the program remains broadly on track. All the quantitative and structural performance criteria, benchmarks, and indicators for end-June 2001 and end-September 2001 were met, except for the indicator on current government revenuc. The performance criteria and benchmarks for the remainder of the program are set out in the technical memorandum of understanding (Appendix I, Attachment II). An outreach to civil society and the press was done at the end of the mission.

5. As of end-September 2001, Burkina Faso's outstanding use of Fund resources amounted to the equivalent to SDR 91.3 million (151.7 percent of quota). Its relations with the Fund are summarized in Appendix II. The World Bank has supported Burkina Faso's reform program since 1994 through a number of sector credits for a total cumulative disbursement through end-August 2001 of US $\$ 121.3$ million. The World Bank also approved in August 2001 a US\$45 million Poverty Reduction Support Credit (PRSC) for Burkina Faso. Burkina Faso's relations with the World Bank are summarized in Appendix III.

6. While Burkina Faso's economic and financial database is adequate, it needs further improvement in the quality, timeliness, and coverage of statistical information, especially for national accounts and balance of payments data. The authorities are addressing these shortcomings and have recently increased the resources devoted to the National Institute of Statistics and Demographics (INSD). Statistical issues are discussed in Appendix IV. A provisional work program for the Fund staff is included in Appendix V.

\section{Recent Economic Performance}

\section{Following a downturn in 2000 owing to a depressed cereals crop, economic} activity remained sluggish during the first semester of 2001. Prices were also affected by the cereals shortage, and the 12-months consumer price inflation rate stood at 4.9 percent at end-September 2001. The real effective exchange rate during the first seven months of 2001 appreciated by about 2 percent over the 2000 average as a result of somewhat higher inflation and the weakening of the U.S. dollar against the euro, to which the CFA franc is pegged. However, the gains in external competiliveness achieved through the 1994 devaluation remained largely preserved (Figure 1). Broad money grew slightly, by 1.1 percent, during the first semester of 2001, and credit to the cconomy remained almost flat over the period despitc some delays in cotton crop credit reimbursements, which were explained by postponed cotton shipments.

\section{A. Fiscal Stance}

8. At end-June 2001, the overall fiscal deficit was somewhat larger than targeted, as a significant shortfall in revenue was not fully compensated by curtailments in public outlays. Fiscal revenue was 2.9 percentage points of GDP below the program target as a result of the adverse effect on corporate taxes of the 2000 economic downturn, some delays in the implementation of the new petroleum tax mechanism, and worse-than-usual seasonal pattern (Table 3). External assistance was also lower than anticipated. The two elements 
concurred to generate liquidity lensions at the treasury. To adjust for this shortfall, the government tightened current outlays by 0.4 percent of GDP while protecting social expenditure; also, it issued six-month treasury bills ${ }^{3}$ in Fcbruary, while observing the end-June criterion on net bank credil to the government. Wagc outlays were in line with the program target.

\section{B. Soundness of the Banking System}

9. The lending rates of the Central Bank of Wcst African States (BCEAO) remained unchanged during the first eight months of the year, while auctions of central bank notes were renewed in August. The banking system remains relatively healthy, even though nonperforming loans increascd slightly because banks do not provision their new nonperforming loans until the end of the calendar ycar. The position of one of the main local banks, weakened by the withdrawal in early 2001 of its foreign sharcholder, has not yet improved. As regards prudential regulations, threc banks already comply with the new capital adequacy ratio of 8 percent that will bccome effective on January 1, 2002, and the others plan to increase their capital basc before years-end in order to comply with this core ratio. The regional banking commission lifted the temporary administration of onc financial institution after it increased its capital base.

\section{Structural Reforms}

10. As detailed in the MEFP, all the structural reforms were implemented as planned. The interconnection of the payroll and civil service databases and the setup of a centralized database to track social outlays and outcomes were both effected before end-June 2001. The deposits of the Postal Savings Bank with the Burkinabé Treasury, which were not liquid, were securitized before end-September 2001 for an amount equivalent to 1.3 percent of GDP, with a maturity of ten years and an interest rate of 6.5 percent. The last remaining payment arrears to the electricity company, SONABEL, have also been securitized.

\section{Policy Discussions}

\section{A. Economic Prospects}

11. Growth is expected to rebound during the last quarter of 2001 as preliminary information points to very good ccreals and cotton crops nationwide, owing to abundant rainfall. Real GDP growth could reach 6.2 percent in 2001 (Table 2). Cotton production, in particular, is expected to increase by 45 percent to 400,000 tons, the largest cotton crop ever recorded in Burkina Faso, as produccrs have responded to the announcement in March 2001

\footnotetext{
${ }^{3}$ Several public entitics purchased government treasury bills, including the social security institution, the postal service, the cotton company, and the telecommunications company,
} 
of an increase in farmgate prices of 18 percent $^{4}$ by raising the cultivated area by 35 percent. This is expected to have a major impact on reducing poverty in rural areas (Box 1). The secondary and tertiary sectors, hampered by a depressed demand in the first half of the year, should exhibit lower growth rates ( 3.3 and 4.9 percent, respectively). The good cereals crop should abate price pressures in the latter part of the year, and the increase in the consumer price index could average 3 percent for 2001 .

12. While an appropriate policy of forward sales should allow the cotton monopsony, SOFITEX, to break even this year, notwithstanding the significant drop in international cotton prices since mid-2001, ${ }^{5}$ the staff raised serious concerns about the sector in 2002 . Calculations show that, to break even in $2002 / 03$ with the present international price ${ }^{6}$ unchanged, the producer price in Burkina Faso would have to be lowered by 16 percent to CFAF 147 per kilogram of seed cotton. The government indicated its reluctance to reduce the producer price (now CFAF 175 per kilogram), as it wishes to preserve the poverty reduction benefit of larger cotton crops and associated cereals. ${ }^{7}$ Hence, to ensure the equilibrium of the sector, a subsidy of CFAF 28 per kilogram of seed cotton would have to be paid, at a cost of CFAF 11.2 billion (US $\$ 16$ million, or 0.6 percent of GDP). Such a subsidy appears to be financeable through further cost-cutting measures and possible supplementary donor assistance. ${ }^{8}$ If needed, augmentation in access under the PRGF might be considered as the Fund's possible contribution to this package. However, if world prices were to fall further, the present producer price would not be sustainable and would have to be reduced, impairing growth prospects, the external accounts, and poverty outcomes. The authorities, in consultation with civil society, are exploring a number of countervailing measures to mitigate the negative impact on the poor should reductions in producer prices become inevitable.

\footnotetext{
${ }^{4}$ The producer price was raised by 10 percent (from CFAF 159 to CFAF $175 / \mathrm{kg}$ of seed cotton) on the basis of the strength of international cotton prices in late 2000 ; moreover a bonus of CFAF $25 / \mathrm{kg}$ will be paid, representing the distribution of half of SOFITEX pretax profit in the previous campaign.

${ }^{5}$ Because of a decline in demand owing to the economic slowdown in industrial countries and increases in subsidies paid to U.S. cotton growers, prices in early October 2001 were 40 percent lower than in December 2000 and may remain at that low level, according to World Economic Outlook (WEO) forecasts.

${ }^{6}$ US $\$ 0.389$ per pound of fiber in early October 2001, equivalent to CFAF 600 per kilogram at an exchange rate of US $\$ 1=\mathrm{CFAF} 700$.

${ }^{7}$ The impact of different scenarios on cotton farmers' revenue is shown in Box 1.

${ }^{8}$ The European Union has already indicated that a Stabilization System for Export Earnings (STABEX) disbursement could be possible.
} 


\section{Box 1. The Cotton Sector in Burkina Faso: Reforms, Social Impact, and Outlook}

Since the end of 1998 , the cotton sector has been gradually reformed and liberalized. In particular, producer's associations have been strengthened, and 30 percent of the state monopsony, SOFITEX has been sold to them, with the siate becoming a minority sharcholder, with only 36 percent of capital. New planting zones have been opened where the private sector is free to invest in ginning activities. SOFITEX is planning to gradually sell its ginning factories. The transportation activities have been spun off to the private sector. Crop credits are now extended to the producers' associations using joint guarantees (cautionnement solidaire) at the level of each association. As a result, performing producers have weeded out poorly performing ones, and productivity has increased significantly (yields improved by 31 percent in 1999/2000). The cotton is sold to SOFITEX at a fixed producer price plus a bonus representing the distribution of half of SOFITEX pretax profit in the previous campaign.

Burkina Faso: Performance of the Cotton Sector, 1997/98-2001/02

\begin{tabular}{|c|c|c|c|c|c|}
\hline & $1997 / 98$ & $1998 / 99$ & $1999 / 2000$ & $2000 / 01$ & $\begin{array}{r}2001 / 02 \\
\text { Proj. }\end{array}$ \\
\hline & \multicolumn{5}{|c|}{ (lu units indicated) } \\
\hline \multicolumn{6}{|l|}{$\begin{array}{l}\text { Producer price of seed } \\
\text { collon (CFA francs per kilogram) }\end{array}$} \\
\hline Price & 159.0 & 159.0 & 158.0 & 159.0 & 175.0 \\
\hline Bonus & 20.0 & 25.0 & 25.0 & 10.0 & 250 \\
\hline Total & 179.0 & 184.0 & 183.0 & 169.0 & 2000 \\
\hline Cultivated aren (thousands of hectares) & 290.5 & 3.52 .5 & 240.5 & 260.0 & 350.0 \\
\hline (percent increase) & 33.0 & 21.3 & -31.8 & 8.1 & 34.6 \\
\hline Yields (kilograms of seed cotton per & $1,164.0$ & 807.0 & $1,057.0$ & $1,055.0$ & $1,143.0$ \\
\hline (percent increase) & 18.6 & -30.7 & 31.0 & -0.2 & 8.3 \\
\hline \multicolumn{6}{|l|}{ Production of secd cotton } \\
\hline (thousands of metric tons) & 338.1 & 284.5 & 254.2 & 274.3 & 400.0 \\
\hline \multicolumn{6}{|l|}{ Yield cotton fibet / seed } \\
\hline (in percent) & 41.5 & 41.8 & 42.9 & 42.2 & 42.0 \\
\hline \multicolumn{6}{|l|}{ Production of ginned cotton } \\
\hline (thousands of metric tons) & 140.5 & 119.0 & 109.1 & 115.6 & 168.0 \\
\hline \multicolumn{6}{|l|}{ Unit value of ginned cotton } \\
\hline & \multicolumn{4}{|c|}{ (CFA francs per kilogram, unless otherwise } & \\
\hline $\begin{array}{l}\text { Total producer price } \\
\text { (fiber equivalent) }\end{array}$ & 430.9 & 439.9 & 426.5 & 400.9 & 476.2 \\
\hline $\begin{array}{l}\text { Average fo.b. export price } \\
\quad \text { (Abidjan) }\end{array}$ & 849.0 & 697.0 & 662.0 & 847.0 & 676.0 \\
\hline $\begin{array}{l}\text { Ratio: producer price/export price fo.b. } \\
\text { (in percent) }\end{array}$ & 50.8 & 63.1 & 64.4 & 47.3 & 70.4 \\
\hline
\end{tabular}




\section{Box 1. The Cotton Sector in Burkina Faso: Reforms, Social Impact, and Outlook (Concluded)}

Ongoing reforms aim at further strengthening producers' associations and progressively limiting SOFITEX's role. A study is being undertaken on the financing by the banking sector of cotton inputs, an activity from which SOFITEX intends to withdraw as of the $2002 / 03$ season. Also, some microlinance networks are expanding rapidly in the cotton-producing regions, which should help broaden the access of producers' associations to credit. The development of new cotton-growing regions, fully managed by the private sector, should further promote competition in the sector. Finally, the state has indicated its intention to further reduce its shareholding in SOFITEX in favor of the producers' associations.

The potential for improvement in the cotton sector is still very large because endowments in machinery and technical know-how are poor and unevenly distributed. Following the increase in the producer price from CFAF 159 per kilogram of cottonseed in 2000/01 to CFAF 175 per kilogram (plus a bonus of CFAF 25 per kilogram) in $2001 / 02$, the cultivated areas are estimated to have risen by close to 35 percent. Continued efficiency efforts further strengthencd the gains in yields by an estimated 8.3 percent. Overall, seed cotton production is expected to increase by about 45.8 percent to reach 400,000 tons. The higher producer price and larger production in 2001/02 should increase producers' gross revenue by aboul 72.6 percent, contributing to about 21 percent of GDP growth in 2001. The impact on poverty will be significant, as cotton producers represent 18 percent of the population. Moreover, this increase in revenue is likely to have positive spillovers on other sectors of the economy. With the growth multiplicr estimated for Burkina Faso, ${ }^{2}$ the increase in cotton growers' gross revenue (CFAF 33.6 billion, or 2 percent of GDP) should generate another 3.7 percent of GDP in local nontradable income. Also, a stronger cotton production bas a direct impact on ginning and transport activities that will mainly materialize in 2002 . All this could be reversed in $2002 / 03$ if world prices continue to fall: the producer prices would need to be cut, lowering growth and farmers' incomes, with a concomitant negative impact on poverty outcomes

Burkina Faso: Impact of Cotton Production on Incomes, 1998/99-2002/03

\begin{tabular}{|c|c|c|c|c|c|c|c|}
\hline & \multirow[t]{2}{*}{$1998 / 99$} & \multirow[t]{2}{*}{ 1999/00 } & \multirow[t]{2}{*}{$2000 / 01$} & \multirow[t]{2}{*}{$2001 / 02$} & \multicolumn{3}{|c|}{$2002 / 03$} \\
\hline & & & & & scen. 1 & scen. 2 & scen. 3 \\
\hline $\begin{array}{l}\text { Production of seed cotton } \\
\text { (thousands of metric tons) }\end{array}$ & 284.5 & 254.2 & 274.3 & 400.0 & 420.0 & 400.0 & 380.0 \\
\hline $\begin{array}{l}\text { Producer price of seed } \\
\text { (seed equivalent CFA francs per kilogram) }\end{array}$ & 184.0 & 183.0 & 169.0 & 200.0 & 175.0 & 175.0 & 147.0 \\
\hline $\begin{array}{l}\text { Producers' gross revenue } \\
\text { (billions of CFA francs) }\end{array}$ & 52.3 & 46.5 & 46.4 & 80.0 & 73.5 & 70.0 & 55.9 \\
\hline (percent change) & -13.5 & -11.1 & -0.4 & 72.6 & -8.1 & -12.5 & -30.2 \\
\hline (in percent of GDP) & 3.6 & 3.1 & 3.0 & 4.7 & 4.0 & 3.8 & 3.0 \\
\hline Change in producers' gross revenue & & & & & & & \\
\hline (billions of CFA francs) & -8.2 & -5.8 & -0.2 & 33.6 & -6.5 & -10.0 & -24.1 \\
\hline (contribution to change in GDP, in percent) & -6.2 & -11.3 & -0.4 & 21.2 & -4.7 & -7.3 & -17.5 \\
\hline
\end{tabular}

Source: Société des Fibres Textiles (SOFITEX) and staff calculations

${ }^{1}$ For details on earlier reforms, sec SM/00/115 (6/13/00), Appendix I.

${ }^{2}$ Footnote 5, page 13, Burkina Faso, Country Assistance Strategy, Report No. 21285-BUR, (November 2000), notes: "Growth multipliers for Burkina Faso indicate that for each dollar of income generated in the agricultural tradable sector $\$ 1.88$ of additional income will be generated in the local nontradable sector due to linkages." 
13. Real GDP growth could reach 5.8 percent in 2002. Assuming normal weather conditions and no further decline in the international cotton price, agricultural output is projected to expand at a moderate pace of 4 percent after the high level attained in 2001. The bumper crops of late 2001 should benefit ginning, transportation, and trade activities, and the secondary and tertiary sectors are projected to grow by about 7.5 percent and 6.5 percent, respectively. With a continued improvement of the savings rate and the investment rate remaining at about $271 / 2$ percent, the savings-investment gap is likely to narrow to 10.4 percent of GDP in 2002 from 14 percent in 2001 (Figure 2). The GDP deflator is projected at about 2 percent. For 2003-05, real GDP growth could remain a little above 5 percent in the absence of drought and with the maintenance of sound economic policies. In light of the higher-than-usual uncertainties, the staff and the authorities reviewed the

downside risk scenario, which is predicated on lower agricultural output and smaller flows of workers' remittances. The results indicated that real GDP would grow by about 4.5 percent a year, the savings-investment balance would deteriorate, the external current account deficit would widen and fiscal financing gaps, however sustainable and financeable through a mix of domestic adjustment and some additional financing, would emerge (see Appendix VI).

However, the staff indicated that growth could be even lower if world cotton prices were to decline further. The impact of recent events on lower export prices have already been factored in the downward risk scenario; the additional impact on Burkina Faso's economy is expected to be small, as the negative effect of the global slowdown in the world economy is outweighed by the decline in petroleum products prices. A poverty and social impact analysis of the program is provided in Box 2 .

14. Burkina Faso's large external current account deficit is projected to improve in the coming years in the baseline scenario. For 2001, the current account deficit (excluding official transfers) is projected at 17.7 percent of GDP (14 percent of GDP, including grants), 0.9 percentage point wider than programmed, largely owing to higher-than-anticipated oil prices (Figure 3 and Table 7). For 2002, despite the expected drop in CFA franc prices of cotton exports and the related deterioration in the terms of trade, the substantial increase in the volume of cotton harvested in late 2001 but exported in 2002 and an expected modest decline (because of lower oil prices) in the level of imports should reduce the current account deficit (excluding grants) to 14.6 percent of GDP (10.4 percent of GDP, including grants). A further drop in world cotton prices would indeed impair this improvement. In 2001 and 2002, even though workers' remittances will remain at a low level pending the recovery of Côte d'Ivoire's economy, Burkina Faso is expected to contribute positively to the foreign assets position of the BCEAO. Burkina Faso's current account deficit should continue to narrow in the medium term, mainly as a result of an expected increase in cotton exports and decline in imports of capital goods. ${ }^{8}$

\footnotetext{
${ }^{8}$ The gradual shift in public investment expenditure to poverty reduction and the improvement of social conditions of the poor are expected to lower the import elasticity to investment.
} 


\section{Box 2. Poverty and Social Impact Analysis of Burkina Faso's Program}

In a country where almost one-half of the population lives below the absolute poverty line, the economic program set up by the government and supporled by the PRGF arrangement takes poverty reduction as an anchor. Since 1999, the government has significantly increased basic education and heal h expenditure and intends to pursue its effort in the 2002 budget and beyond. The bulk of these additional expenditures are directed at rural areas where the majority of the poor live.

The adjustment measures included in the PRGF-supported program with Burkina Faso are not expected to havc any significant adverse effects on the poor. Revenue measures implemented by the government are targeted at higher-income households and business activities in the formal sector. In particular, the impact on the poor of the recent incrcase in petroleum taxation is expected to be limited as (i) the new excises are levied on products mainly used by more affluent households, while the socially sensitive products (such as kerosene and butane gas) remain subsidized; (ii) previous experience indicates that the transport sector tends to absorb small variations of diescl and gasoline prices; and (iii) the short-term adverse impact on consumers would be reversed when international oil prices decline. Moreover, improved government revenue resulting from the higher tax receipts will help to sustain expenditure, including those targeted to the poor.

As presented in paragraph 11 and Box 1, one of the main goals of the program is to secure a profitable price for cotton farmers, as this crop is the main source of cash income in rural areas, while preserving the financial sustainability of the sector. The 2001/02 campaign will result in a significant increase in producers' incomes with a positive impact on reducing poverty, particularly in rural areas. For the 2002/03 campaign, the program endeavors to preserve the effect of the gains of higher cotton production and prices on poverty outcomes in the face of the declinc in international prices, if necessary through the use of additional external or domestic financing. A more rigorous study providing information on the linkages between producer prices and the poor, and a quantitative assessment of the opportunity costs in terms of other poverty reducing spending, will be undertaken with the assistance from the World Bank and other development partners.

One of the key sectoral measures is the hookup of the electricity grid with that of neighboring countries. The added capacity will allow the electrification of a larger number of villages, and the expected gradual reduction in electricity tariffs will attract industrial investments and create job opportunities, all of which will directly benefit the poor. Moreover, the electrification of a larger number of health centers in villages will allow the maintenance of stocks of essential drugs and vaccines. The limited availability of banking services in nural areas and weaknesses in financial intermediation still limit the share of credit going to the poor. However, the development of a sound microfinance sector takes up some of the slack by helping the poor improve their income-generating activities.

Reforms to improve public finance management and to decentralize expenditure commitments that focus on transparency and accountability should reduce fraud and increase efficiency in the allocation and targeting of increased resources to the poor. In particular, the government's focus on fighting corruption, as demonstrated by the intended creation of an anticorruption unil, should have a positive impact on the poor because they are often the first victims of small-scale corruption. 


\section{B. Fiscal Policy}

15. Despite the revenue shortfall in the first half of the year, the authorities intend to achieve the original 2001 program objective of a basic fiscal deficit (excluding the use of HIPC Initiative resources) of $\mathbf{1 . 4}$ percent of GDP and an overall fiscal deficit (on a commitment basis and including grants) of about 5 percent (13.6 percent of GDP excluding grants) (Figure 4). Overall revenue is projected at 0.8 percentage point of GDP below program, with tax revenue expected to reach 14 percent of GDP, 0.5 percentage point lower than originally programmed. To secure this revenue level, the authorities have increased the excise tax on premium and regular gasoline, introduced an excise tax on diesel, and are performing a full fiscal census. As explained in paragraph 7 of the MEFP and in Box 2, the impact on the poor of the increase in petroleum taxation is slight.

16. To offset the revenue shortfall, the government intends to limit current expenditure to 12.8 percent of GDP in $2001,0.8$ percent of GDP lower than originally programmed. To achieve this objective, current expenditure will be cut by 0.8 percentage point of GDP while social outlays will be protected, subsidies on socially sensitive petroleum products will end up lower than programmed by 0.3 percent of GDP because of the decline in international oil prices, while the wage bill was revised upward by 0.3 percent of GDP. This was done to accommodate new hiring, mainly in the social sectors, and some retroactive wage and indemnities adjustments linked to the introduction of the new salary grid. The staff strongly argued that the retroactive wage adjustments reflected unwarranted weaknesses in the management of personnel databases that should be avoided in future years. The authorities ensured the mission that with the recently installed interconnection of the payroll and civil service databases, this problem would be addressed for future years. However, the full review of the antiquated grid of indemnities is welcome: although it will increase the wage bill somewhat, it improves equity, and the trade unions pledged in return to guarantee social peace in the civil service for the next five years. Investment expenditures remain as programmed at about 15.7 percent of GDP. The foreign financing of the central government, which was below program at end-September because of delays in adjustment lending by the World Bank and the African Development Bank, will end up somewhat above program for the whole year due to the higher-than-projected assistance under IDA's PRSC. All in all, the net bank position of treasury will decrease by 0.3 percent of GDP, as programmed.

\section{Social outlays will continue their upward trend in 2001 (Tables 4-6 and}

Figures 5-7). Reflecting the desire to execute the poverty reduction program embedded in the PRSP in its entirety, the authorities have decided to use 0.2 percent of GDP in budgetary resources to make up for shortfalls and delays in HIPC Initiative contributions," in order to execute the share of the social expenditure program funded by HIPC Initiative related resources as initially budgeted ( 1.5 percent of GDP). Of this total, 61 percent was allocated

\footnotetext{
${ }^{9}$ The participation of some creditors in Burkina Faso's debt reduction under the HIPC Initiative is still uncertain, and some others declined have to provide interim assistance.
} 
for investment outlays and the remainder for current expenditures. Overall social outlays are projected at 24.8 percent of total expenditure, or 7 percent of GDP (up from 22.3 percent and 6.2 percent, respectively, in 2000 ).

18. For 2002, the overall deficit (on a commitment basis, including grants) is expected to decline by about 1 percent of GDP to 4 percent of GDP (12.1 percent of GDP excluding grants), with tax revenue buoyed by the rebound in growth, rising by 0.5 percent of GDP to 14.5 percent of GDP, and current expenditure remaining subdued. A number of tax and expenditure measures included in the 2002 draft budget are summarized in paragraphs 17 and 18 of the MEFP. In particular, there will be no general wage increase in 2002, with the growth of the wage bill accounted for by the wage drift, some further recruitment in the social sectors, and an allowance for the planned adjustments in indemnities. In line with the PRSP, the 2002 draft budget plans to increase resources available for priority sectors, such as basic education, health, and decentralization, while curbing those available for defense and the presidency (Box 3).

\section{Monetary and Banking Policy}

19. Monetary policy, conducted by the BCEAO at the regional level, will continue to focus on preserving the peg of the CFA franc to the euro and consolidating official reserves. Burkina Faso's contribution to these objectives in 2001 and 2002 will be some buildup of the net foreign assets position and a small reduction in government borrowing from the banking system. This will leave enough room for credit to the private sector to grow by about 9 percent, consistent with projected trends in economic activity (Table 9). Money supply is projected to expand in line with nominal GDP growth. The staff asked the authorities (i) to expedite the search for a new private partner to consolidate the main local bank, weakened by the withdrawal in early 2001 of its foreign shareholder; (ii) to encourage the banks to increase capital and reserves, so as to comply with the new capital adequacy ratio that will become effective on January 1, 2002; and (iii) to continue to promote a sound development of microfinance, including through a strengthening of the supervisory capacity. To facilitate the implementation of the West African Economic Monetary Union (WAEMU) Council of Ministers' decision to eliminate statutory advances from the BCEAO and to permit full substitutability between bank financing and treasury bills or bonds, the key performance criterion on the change in net bank credit to the government will be replaced from 2002 onward with a performance criterion on net domestic financing (bank and nonbank). 


\section{Box 3. Comparison of Budgetary Allocations in 2001 and 2002}

As indicated in the figure below, the $2002 \mathrm{draft}$ budget increases allocations for priority sectors (notably primary education, decentralization, and justice and human rights), while keeping those in the area of sovereignty (e.g., defense and presidency) well below the average increase.

Increase in Budgetary Allocatious for Selected Ministries $\mathbf{V}$

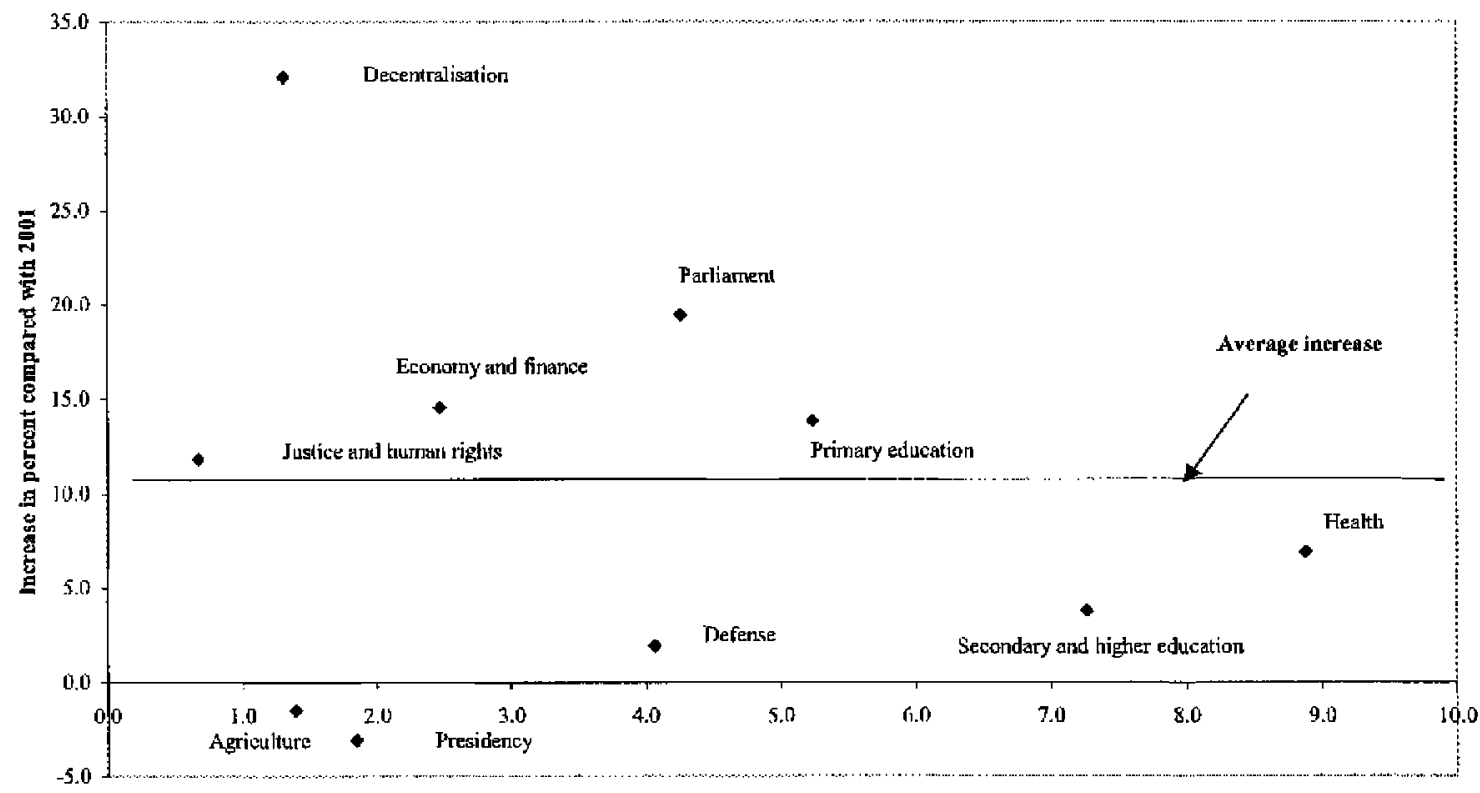

Share in the 2002 hudget (in percent)

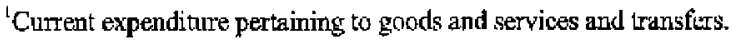

\section{Structural Reforms}

20. The coverage of structural conditionality in the program remains streamlined, with measures outside the PRGF arrangement covered by conditionality in other donorsupported programs (Box 4). The main structural reforms, in particular the privatization agenda (Table 10), reform of the cotton and energy sectors, and program for the promotion of private sector activities, undertaken with the assistance of the World Bank, are described in paragraphs 21-23 of the MEFP. The improvement of public finance management will remain a focal point for the IMF-supported program (MEFP, para 12). Progress in cashflow management at the treasury will be achieved by closing a large number of accounts in the treasury's books, in particular those of the private scetor. With the assistance of the World Bank, the Budgel Management Improvement Plan (PRGB) was adopted in September 2001 and a Country Financial Accountability Assessment is scheduled to be 


\section{Box 4. Structnral Conditionality}

Coverage of structural conditionality in the current program

The structural areas covered by conditionality in the third annual program for 2001/02 (July-June) focus on the core macroeconomic adjustment of the Burkinabe economy and the fight against poverty:

- public finance management (improvement in value-added tax refund procedures and operation of the Supreme Audit Court);

- improvement of the treasury's cash management (closing of accounts with the trcasury, in particular private sector accounts);

- governance (adoption of the audited budget acts for 1999 and 2000 and operation of the anticorruption unit); and

- poverty alleviation (activation of the centralized database on poverty outlays and outcomes).

Relevant structural measures not included in the 2001/02 program, but covered by other agencies:

- The follow-up of the privatization agenda and reform of the energy and telecommunication sectors are adequately covered in specific World Bank-supported programs.

- The reform of the cotton sector is being pursued with the assistance of the World Bank, and France.

- The implementation of the private sector support program benefits from the assistance of the World Bank and the European Union (EU).

- The promotion of good governance is a conditionality pursued by most donors.

- The strengthening of the judicial system benefits from the assistance of the World Bank, the EU, and France.

- All donors have made the fight against poverty their priority action, and donors are closely coordinating their assistance.

Status of structural conditionality from earlier programs

Structural conditionality in earlier programs, focusing essentially on the privatization program, reform of the energy, telccommunications and cotton sectors, and governance, has largely been met.

Structural areas covered by World Bank lending and conditionality.

$\begin{array}{lll}\text { Reform Measures } & \text { Timing } & \text { Loan Instrument } \\ \text { Public expenditure management } & 2001-03 & \begin{array}{l}\text { Poverty Reduction Support Credit } \\ \text { (PRSC) I, II, III }\end{array} \\ \text { Private sector development } & 2001-03 & \begin{array}{l}\text { PRC and competitiveness credit } \\ \text { Basic education-adaptable } \\ \text { Program loan }\end{array} \\ \text { Health } & 2001-03 & \begin{array}{l}\text { PRSC and HIV/AIDS disaster } \\ \text { response project } \\ \text { Community-based rural } \\ \text { development credit }\end{array} \\ \text { Rural development } & 2001-03 & \begin{array}{l}\text { Urban environment project } \\ \text { Energy sector credit and PRSC II }\end{array} \\ \text { Water and urban } & 2001-03 & \text { and III }\end{array}$


completed by end-2001. The preparation of the audited budget acts (lois de règlement) for 1999 and 2000 is already well advanced. To ensure proper budget monitoring, the Supreme Audit Court will be made fully operational by end-December 2001 (a structural benchmark under the program). Good governance remains a central element in the government's strategy. It will be pursued, inter alia, through further progress in the reform of the judiciary, the reform of public contracting procedures, and the setup of an independent entity in charge of anticorruption issucs before end-December 2001 (a structural performance criterion under the program).

\section{E. Regional Integration}

21. Burkina Faso remains one of the most compliant member countries regarding WAEMU's regional norms, including by being the only member country that fully conforms to the regulations pertaining to the common external tariff. It will endeavor to meet the regional convergence criteria within a reasonable time frame (Table 11). It intends to reduce its still long list of administratively set customs valucs in accordance with the WAEMU directive expected to be issued after consultations with the World Trade Organization (WTO). ${ }^{9}$ Also, progress continues to be made in adapting national legislation to comply with the five directives on harmonization of government finance statistics, accounting, and the legal framework.

\section{F. Program Monitoring}

22. The program will continue to be monitored on the basis of semiannual quantitative performance criteria, benchmarks, and indicators as shown in Table 1 of the MEFP and in the technical memorandum of understanding, and by the end-December 2001 structural performance criteria and benchmarks shown in Table 3 of the MEFP. Progress under the 2001/02 program (July-June) will be assessed in the context of a fifth review under the PRGF arrangement, scheduled to be completed no later than end-June 2002. Performance criteria for the seventh disbursement, including the end-June 2002 quantitative performance criteria, will be set during the fifth review.

\section{PoVERTY REDUCTION}

23. The authorities have vigorously pursued their poverty reduction strategy and have improved on the evaluation and monitoring process. The policy reform conditions for the floating completion point under the enhanced HIPC Initiative pertaining to the areas of health, education, and governance had already been met by end-March 2001 and are reviewed in detail in the paper on the enhanced HIPC Initiative completion point for Burkina Faso. A progress report on the first year of implementation of the PRSP, presented together with the

${ }^{9}$ Since all WAEMU momber countries have adopted the WTO compliant transaction value for import valuation, WAEMU will ask the WTO to condone a short list of administratively set customs values under the provisional arrangements of the GATT 
joint staff assessment, was prepared with extensive consultations with civil society during the summer of 2001 and with donors in September 2001. It reviews the progress to date, elaborates on the extensive consultation process and input of civil society in improving the strategy, and presents the amended strategy for the future. Endorsement of this progress report by the Boards of the Fund and the World Bank is a condition for completion of the fourth review. To strengthen monitoring, the comprehensive and centralized database to track the evolution of all poverty reducing spending and outcomes that was put in place in June will be reinforced in the months to come. Also, the action plan on budget management, which was designed to monitor HIPC Initiative related expenditure and other outlays carmarked for poverty reduction and developed wilh the assistance of the Fund's Report on observance of Standards and Codes (ROSC)/HIPC Initiative assessment and action Plan (AAP) mission, is being implemented.

\section{Progress in social outcomes has been satisfactory and goals remain ambitious}

(Figures 8-11). The government efforts to improve the quality of services in health and education will continue to be guided by the ten-year hcalth plan and the education policy letter. The first focuses on solving health problems plaguing the poor, particularly by reducing the cost of access, while the second aims to raise the national primary school enrollment ratio from 42 percent in 2000 to 70 percent by the end of the decade (and to 60 percent for rural children). The domestic counterpart to these programs is the hiring of 5,000 additional teachers and health workers this and the next few years. Significant progress is being made in the fight against HIV/AIDs and sexually transmitted diseases. A strategic framework for the period 2001-05 was adopted and it's financing discussed with donors. Also, a strategy is being defined to assist poor HIV/AIDs victims living in remote areas. In the area of rural development, in line with the PRSP, the emphasis will remain on the construction of rural roads and the promotion of decentralization policies.

\section{The PRSP process has become the core vehicle for coordinating domestic} poverty reduction programs and international support for the strategy. In particular, a number of donors have decided to pool $^{10}$ their provision of assistance to Burkina Faso into budget support of the PRSP process, with minimum joint conditionality beyond a certification of adequate macroeconomic stance provided by the Fund and an annual review of progress under the PRSP.

\section{STAFf APPRAisal}

26. After the slow growth experienced in 2000 , which continued into the first half of 2001, Burkina Faso's economy is experiencing a recovery into growth rates more compatible with its poverty reduction objectives. The cotton growers' reaction to the higher producer price and propitious rainfall will result in a bumper cotton crop and a

\footnotetext{
${ }^{10}$ At present, the group comprises the European Union, Denmark, the Netherlands, Sweden, and Switzerland, but it is open to other donors to join.
} 
significant dent in rural poverty. This outcome, together with an expected favorable cereals crop, should generate a real GDP growth in 2001 higher than 6 percent, or more than 3 percent on a per capita basis. Moreover, for the medium term, the authorities have adopted a more realistic growth scenario of about $5 \frac{1}{2}$ percent per annum underlying the PRSP-an outcome that could be achieved with favorable weather conditions, the maintenance of fiscal consolidation, the pursuit of appropriate liberalization policies and structural reforms, the waging of the fight against corruption, and continued development of human capital.

27. The major risk to the renewed growth lies in the collapse in cotton prices. Because of their desire maintain the poverty reduction benefits of larger cotton crops and associated cereals, the authorities are reluctant to reduce the producer price of seed cotton below CFAF 175 per kilogram. However, the utmost caution needs to be exercised in taking action to preserve the equilibrium of the sector, including through a further decline in operating costs. Such a decline might entail a cut in the producer price, with an ensuing negative impact on growth and poverty.

28. The response to the shortfall in revenue was appropriate. The curtailing current expenditure early on, while preserving social outlays, will allow the government to meet its overall deficit and domestic debt-reduction targets for 2001 while achieving its social objectives. Also, by raising excises on petroleum products, the authorities activated in a timely fashion a contingency revenue measure embedded in the flexible budgelary framework. There is some ambivalence in the staffs' reaction to the upward revision in salary base. On the one hand, the new hiring in the social sectors is a welcome domestic contribution to the poverty reduction effort, and the review of the antiquated grid of indemnities improves equity and secures social peace in the civil service for the next five years; on the other hand, the retroactive wage adjustment reflects unwarranted weaknesses in the management of personnel databases and should not be repeated. After allowing for some more hiring in the social sectors and a second tranche of indemnities adjustments in 2002, the authorities should endeavor to strictly control the wage bill in order to generate higher savings, to be directed to the social sectors, and to observe the regional commitment to limit the wage bill relative to fiscal revenue.

29. The $\mathbf{2 0 0 2}$ budgetary stance remains within the overall program targets. It is based on eflorts to widen the tax base and to limit fraud, while continuing to contain sovereign current outlays and increasing the share of expenditure devoted to the social sectors. This stance is in line with the main challenge for the strengthening of budgetary management over the medium term, namcly, to lower the high tax rates paid by a narrow tax base, while significantly broadening the tax base and continuing to improve the tax and customs administration.

\section{The welcome emphasis of structural reform on improving public finance} management and governance will promote the efficient use of scarce public resources and help attract privatc investment. Also, notwithstanding the electoral contcxt, the authorities should not waver in their determination to strengthen the competitiveness of the economy through further privatization and deregulation, in particular of public utilities. 
31. The authorities should be commended for having already met in March 2001 all the policy reform conditions of the floating completion point under the enhanced HIPC Initiative and for having produced a progress report on the first year of implementation of the PRSP, after extensive consultations with civil society and development partners, that is candid and comprehensive in its coverage. It is welcome that the PRSP process has become the core vehicle to coordinate both domestic poverty reduction strategies and donor contributions. Nonetheless, further efforts arc needed to improve the planning, execution, and tracking of the strategy, notably by eliminating certain bottlenecks observed in the commitment of available resources, and by energicing the monitoring unit created in June 2001 to establish a centralized database on the evolution of social cxpcnditure and its outcomes.

32. Burkina Faso will continue to face risks, particularly of an exogenous nature, that may hinder the successful implementation of its program. These include further declines in international cotton prices, climatic conditions, and unfavorable developments in neighboring countries. Burkina Faso will need to be prepared to strengthen its adjustment efforts-in particular to tighten its fiscal position-if new shocks arisc. Bccause of the observance of all the end-June 2001 and end-September 2001 quantitative and structural performance criteria and benchmarks, as well as the continued determination of the Burkinabè authorities to achicve the program objectives in the macroeconomic, structural, and poverty alleviation areas as cvidenced in the PRSP progress report, the staff recommends endorsement of the PRSP progress report and that the fourth review under the threeyear PRGF arrangement be completed. 
Figure 1. Burkina Faso: Real and Nominal Effective Exchange Rates, January 1990- July 2001 (Index, 1990=100)

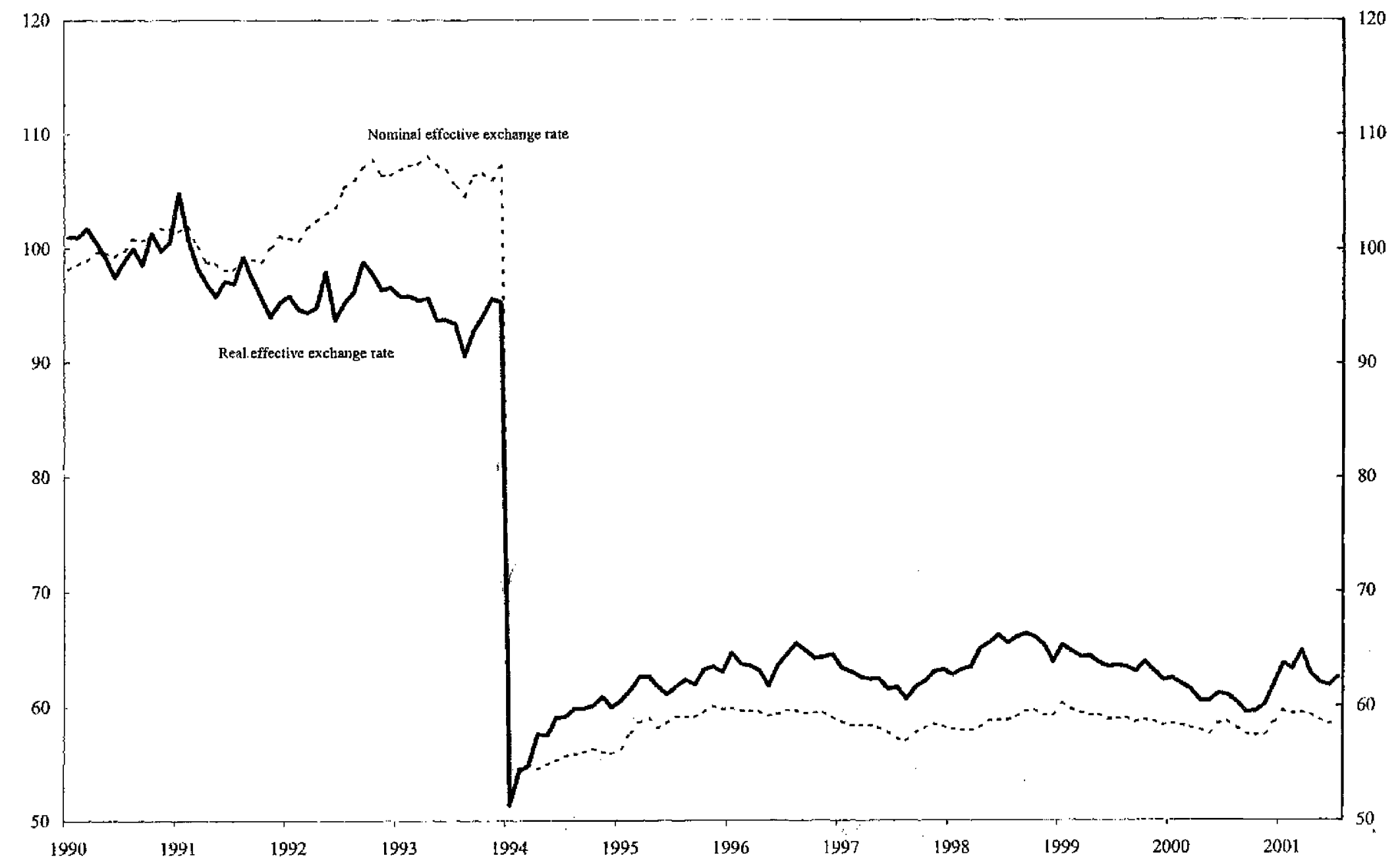

Source: IMF, Information Notice System. 
Figure 2. Burkina Faso: Investment and Savings, 1993-2003 (in percent of GDP)
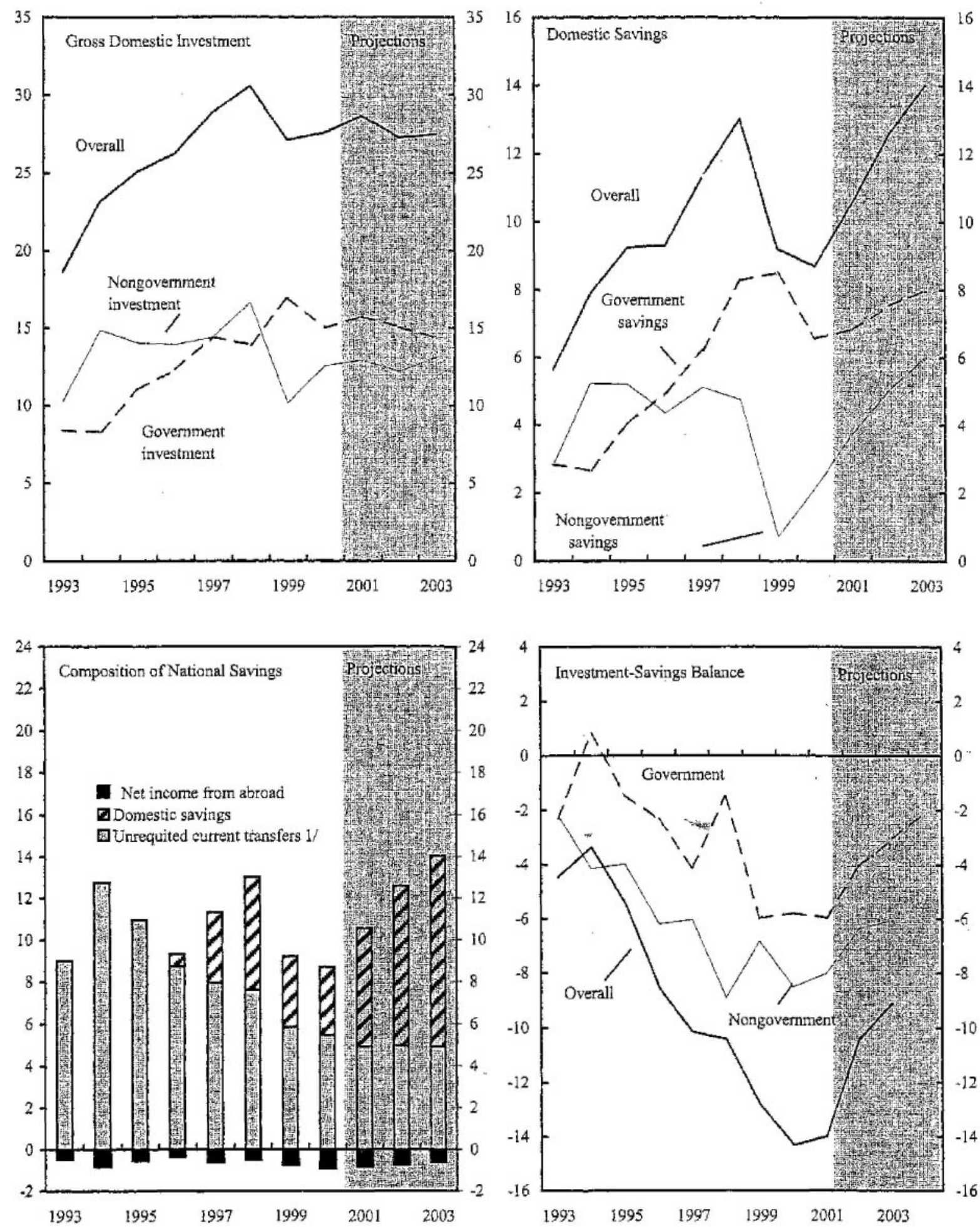

Sources: Burkinabè authorities; and staff estimates and projections.

1/ Budgetary grants, technical assistance, worker remittances, and other transfers, including from nongovernmental organizations. 
Figure 3. Burkina Faso: External Sector Developments, 1993-2003
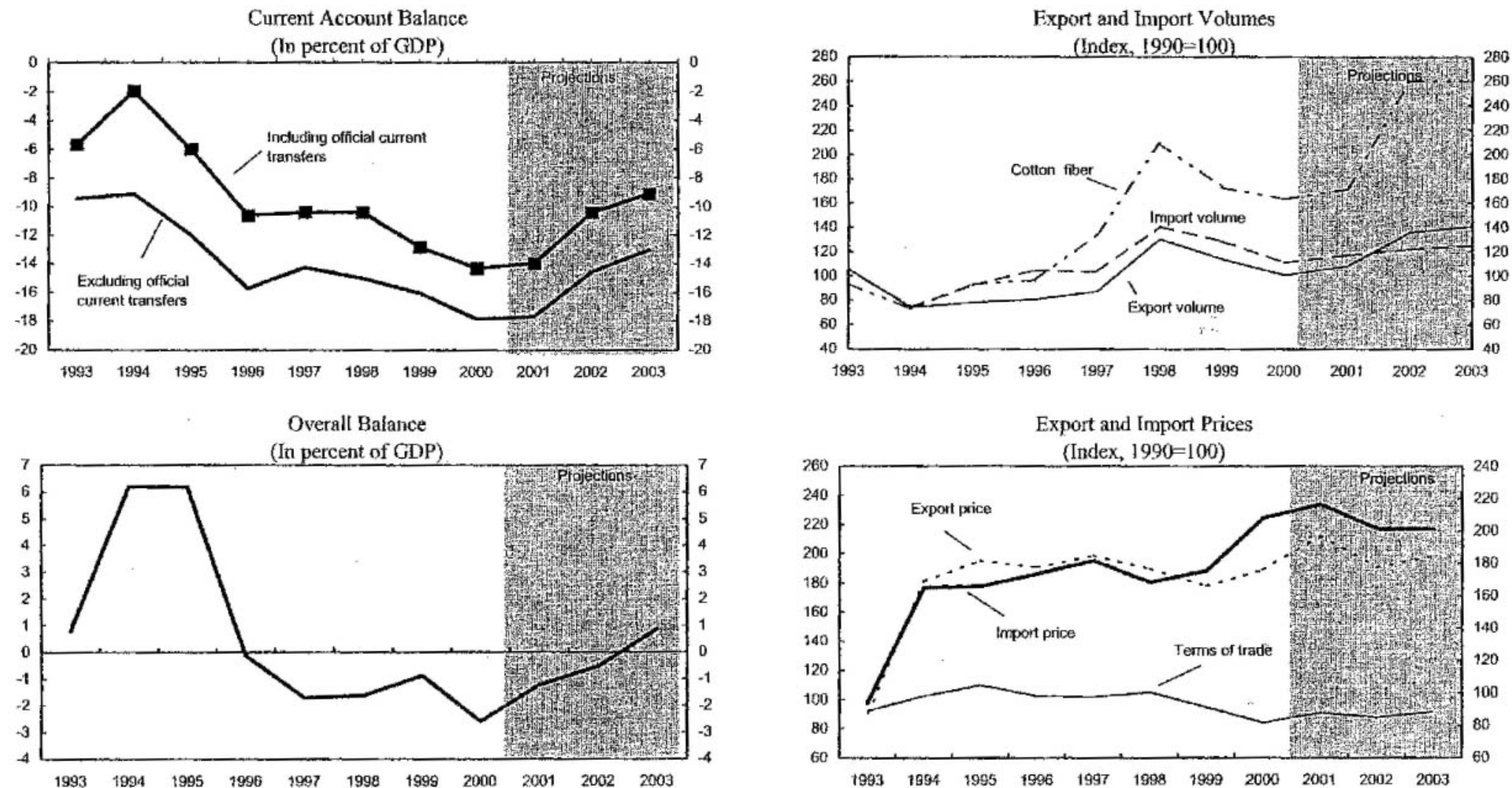

Sources: Burkinabè authorities; and Fund staff estimates and projectionss. 
Figure 4. Burkina Faso: Fiscal Sector Developments, 1994-2003 (In percent of GDP)

Government Revenue and Expenditure

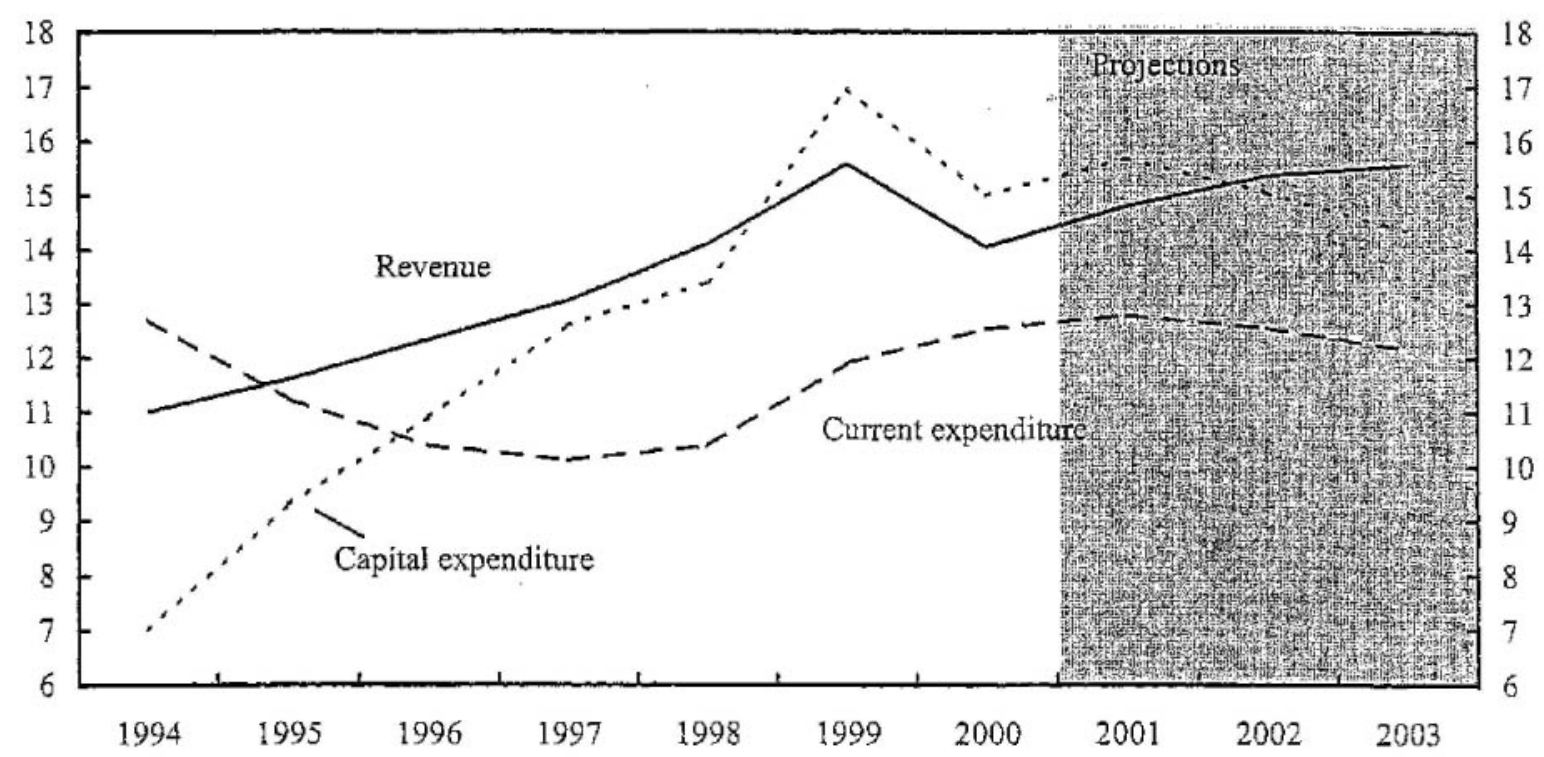

Fiscal Balances

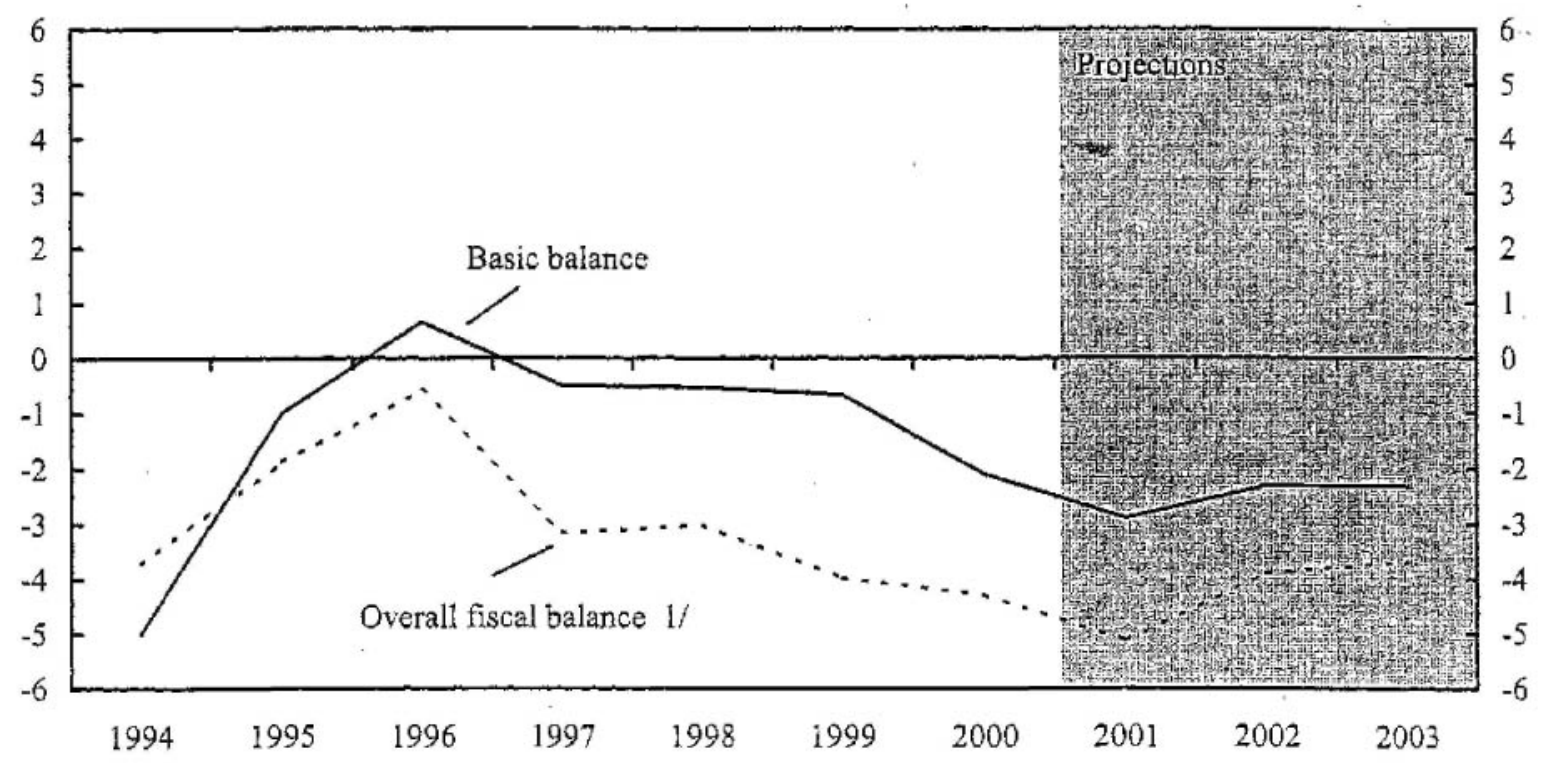

Sources: Burkinabè authorities; and Fund staff estimates and projections.

1/ Commitment basis, including grants. 
Figure 5. Burkjna Faso: Social Expenditures, 1996-2201

(In billions of CFA francs)

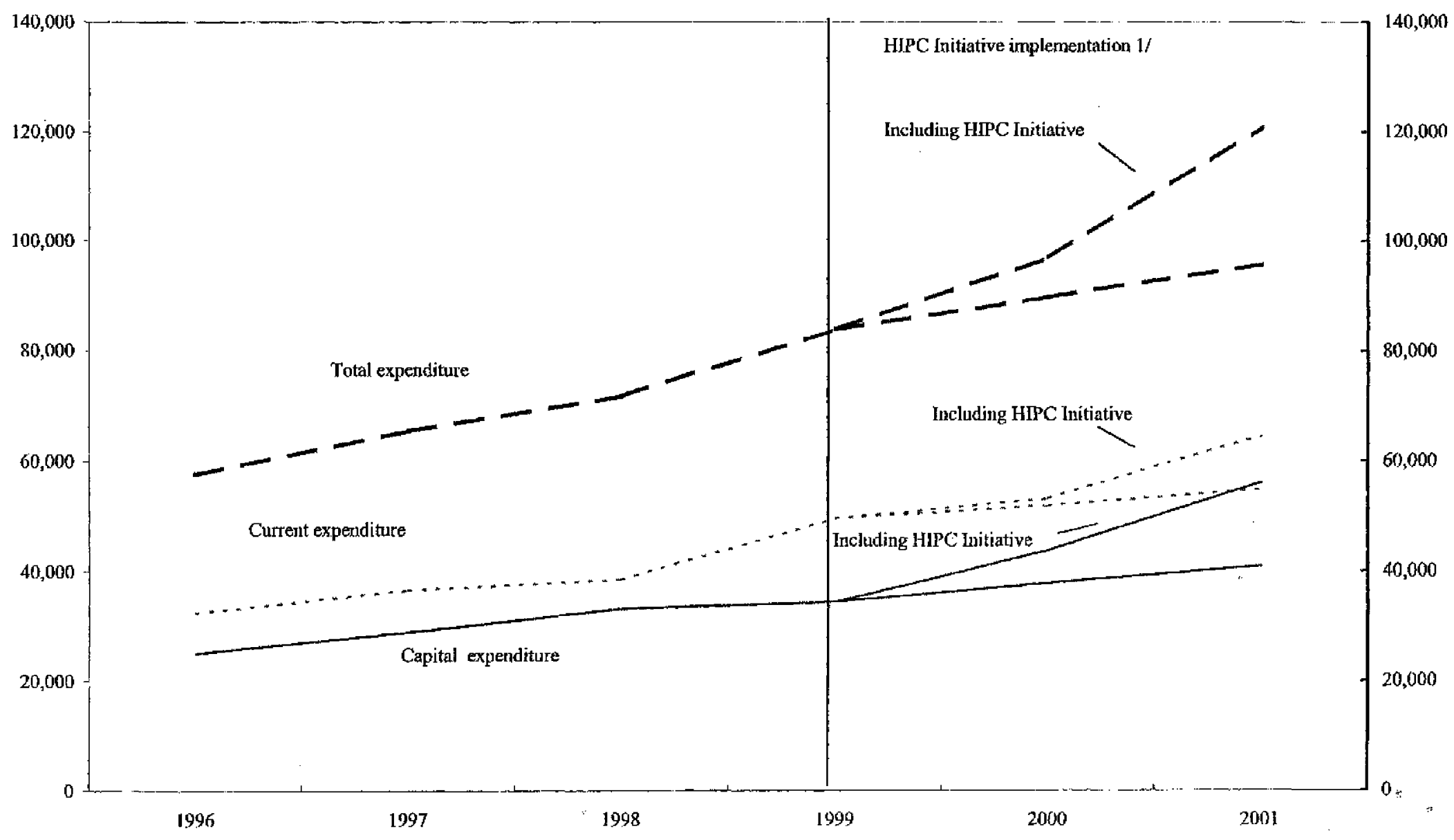

Sources: Burkinabè authorities and Fund staff estimates.

1/ On July 10, 2000, and following the IDA Board's decision of June 30, 2000, the IMF Executive Board agreed that Burkina Faso is eligible for assistance under the enhanced HIPC Initiative. 
Figure 6. Burkina Faso: Distribution of Current Social Expenditures, 1996-2001

(to millions of CFA francs)

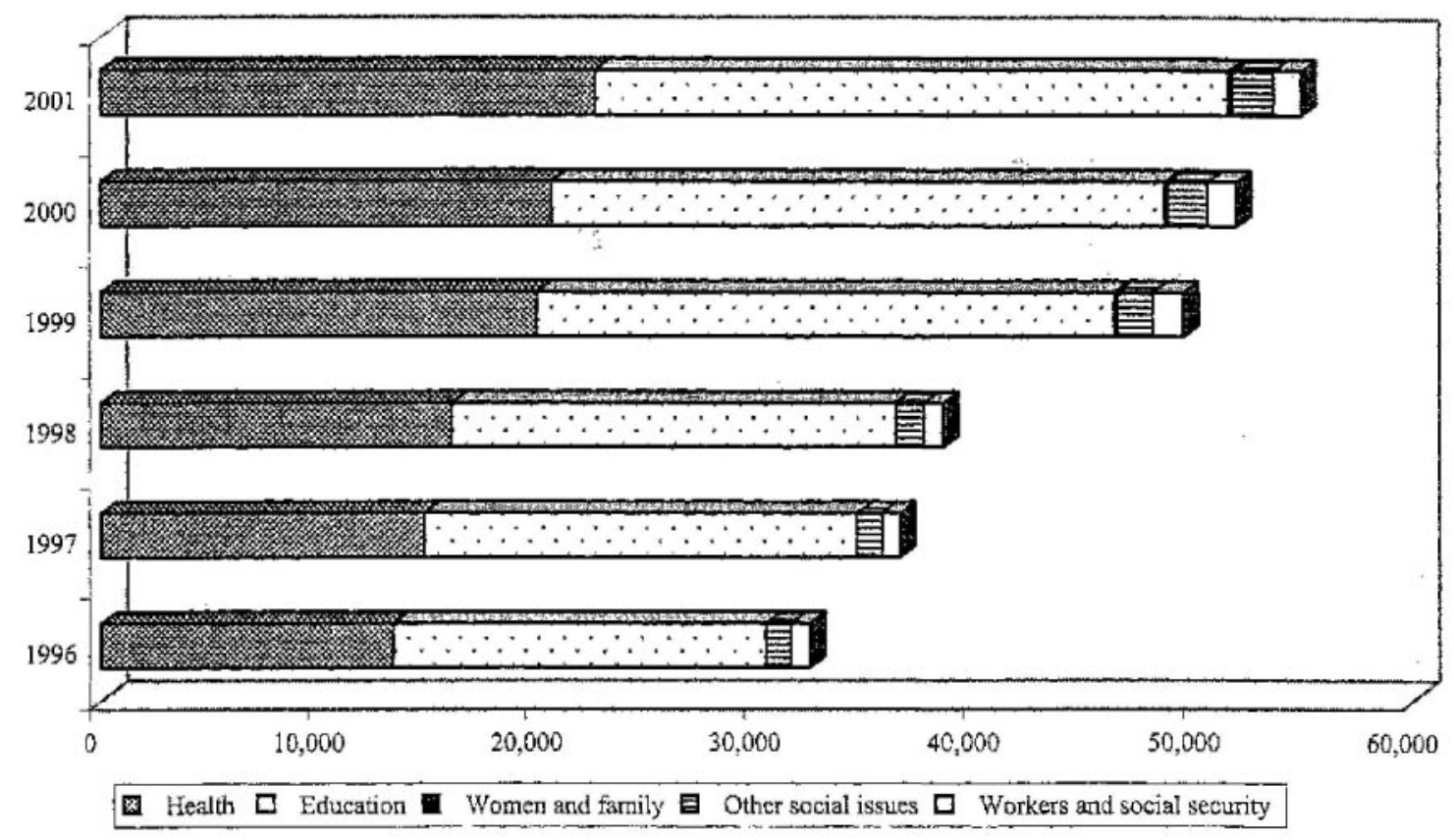

(In percent of total)

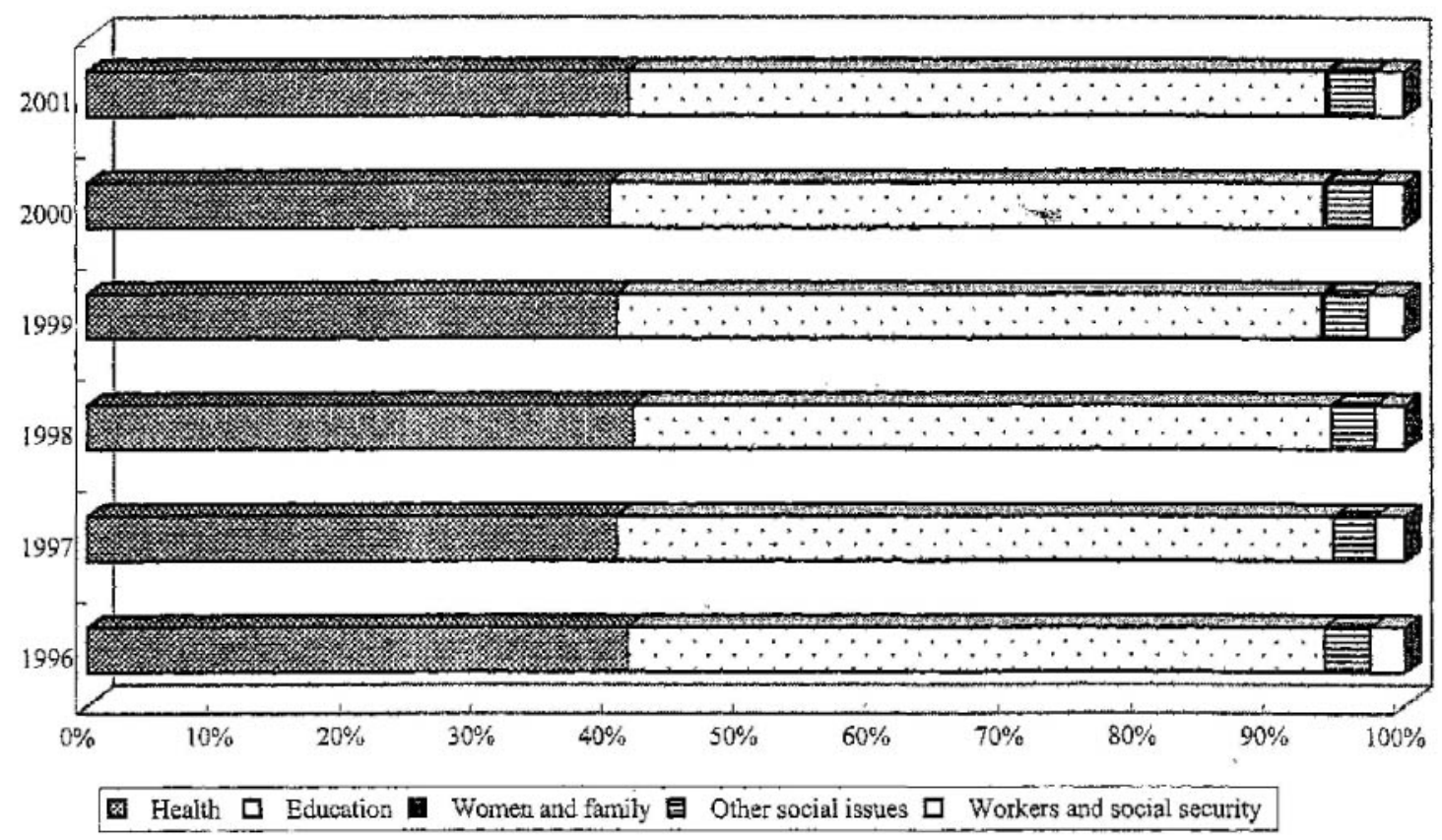

Sources: Burkinabè authorities and Fund staff estimates. 
Figure 7. Burkina Faso: Distribution of Capital Expenditures, 1996-2001

(In millions of CFA francs)

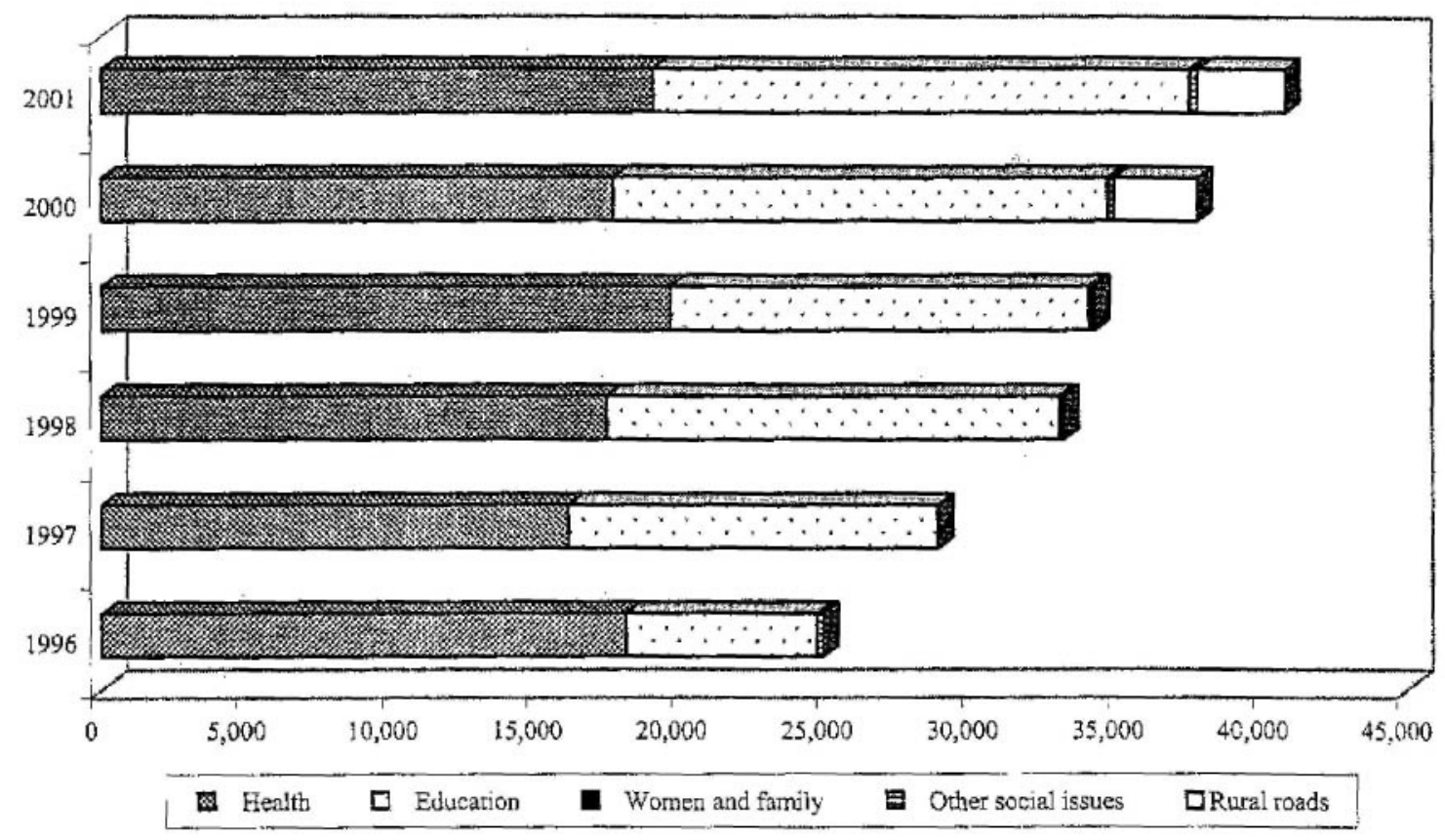

(in percent of total)

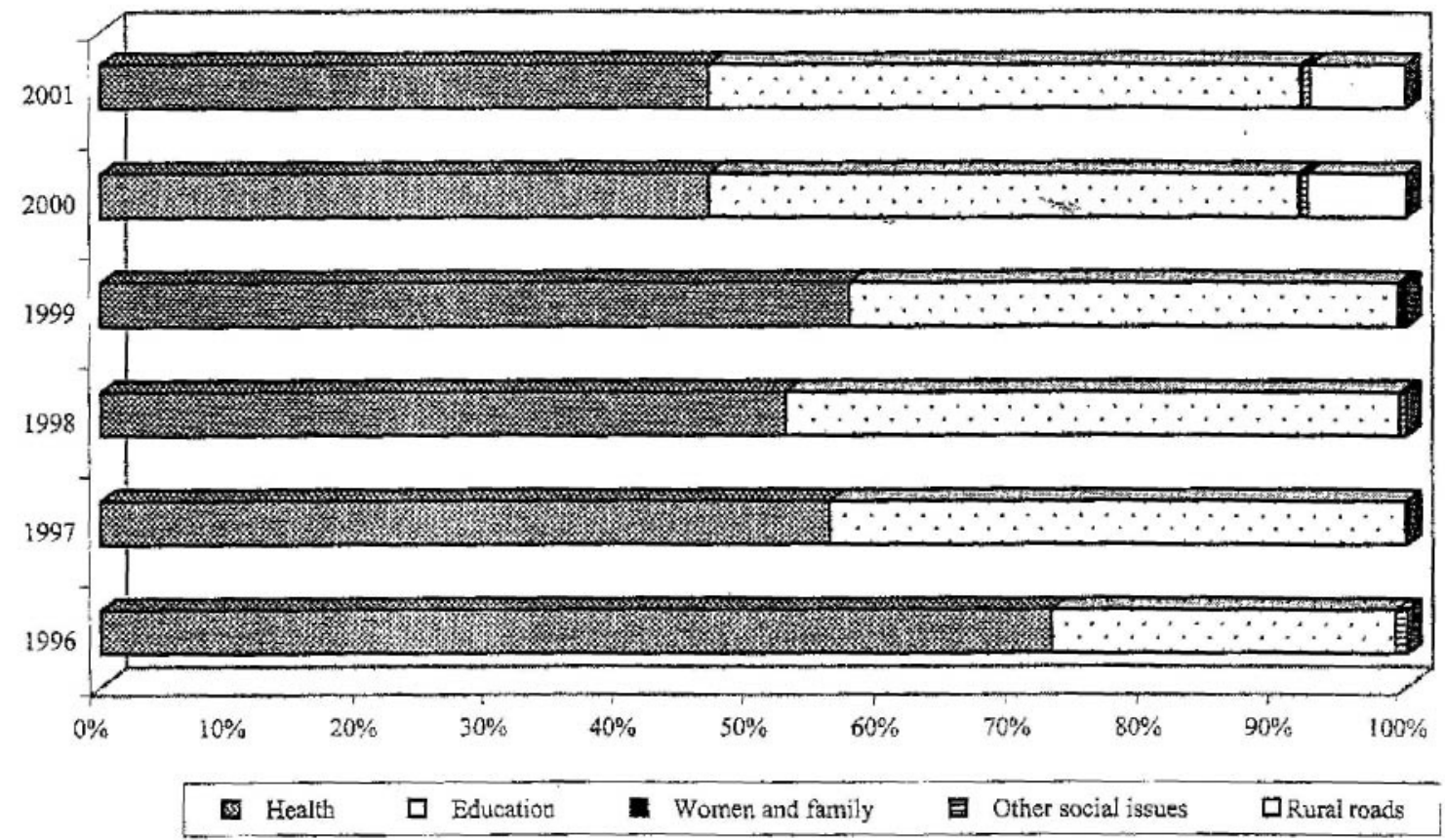

Sources: Burkinabè anthorities; and Fund staff estimates. 
Figure 8. Burkina Faso: Primary School Enrollment Ratio, 1996/97-2003/04 1/

$$
\text { (In percent) }
$$

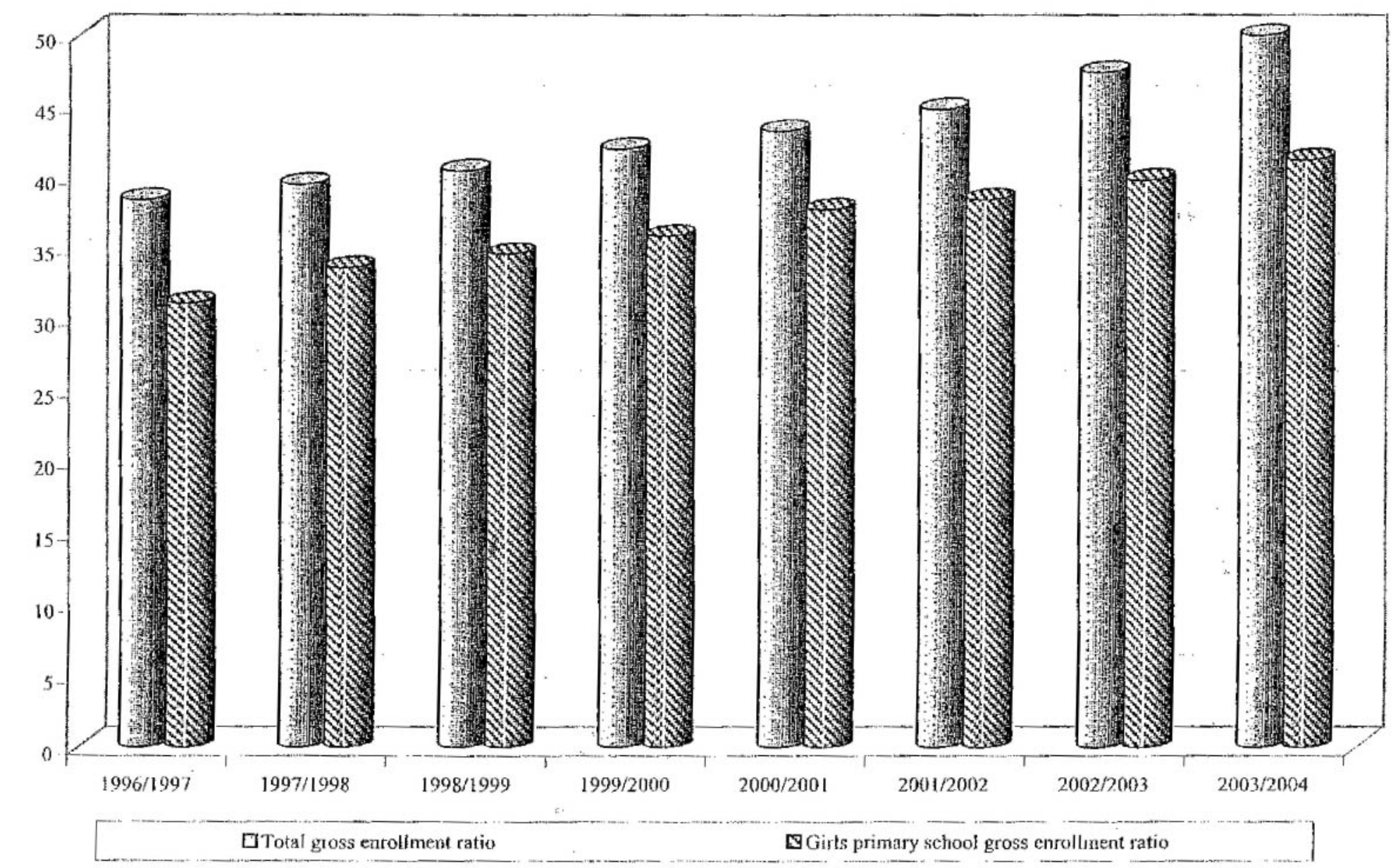

Source: Burkinalıè authorities.

$1 /$ School year is September-June. 
Figure 9. Burkina Faso: Coverage of Basic Education, 1996/97-2003/04 1/

(In percent)

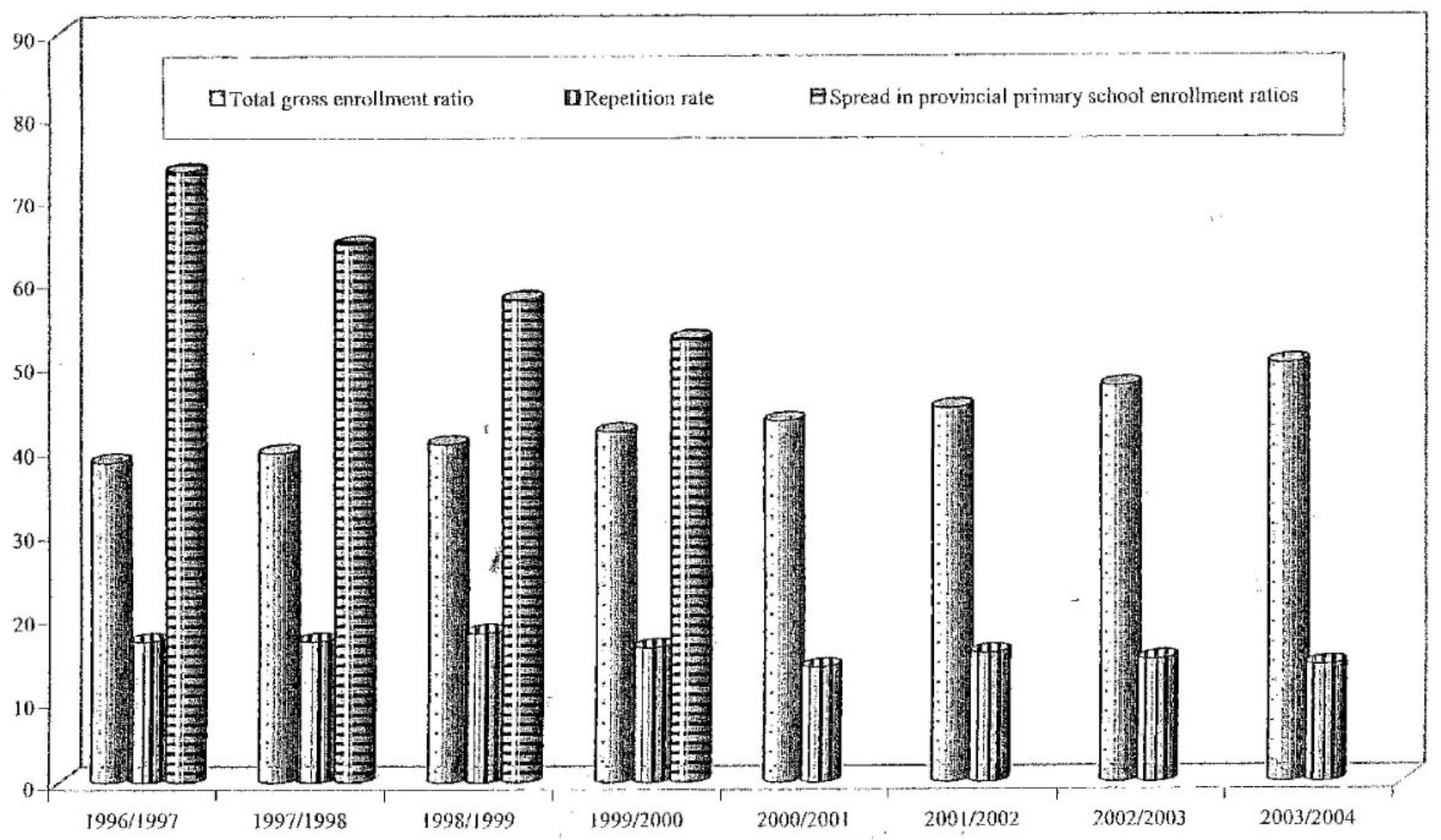

Source: Burkinabè anthorities.

1/ Scliool year is from Septamber to Iune. 
Figure 10. Burkina Faso: Utilization Rate in Health Care Units, 1996-2003 1/ (In percent)

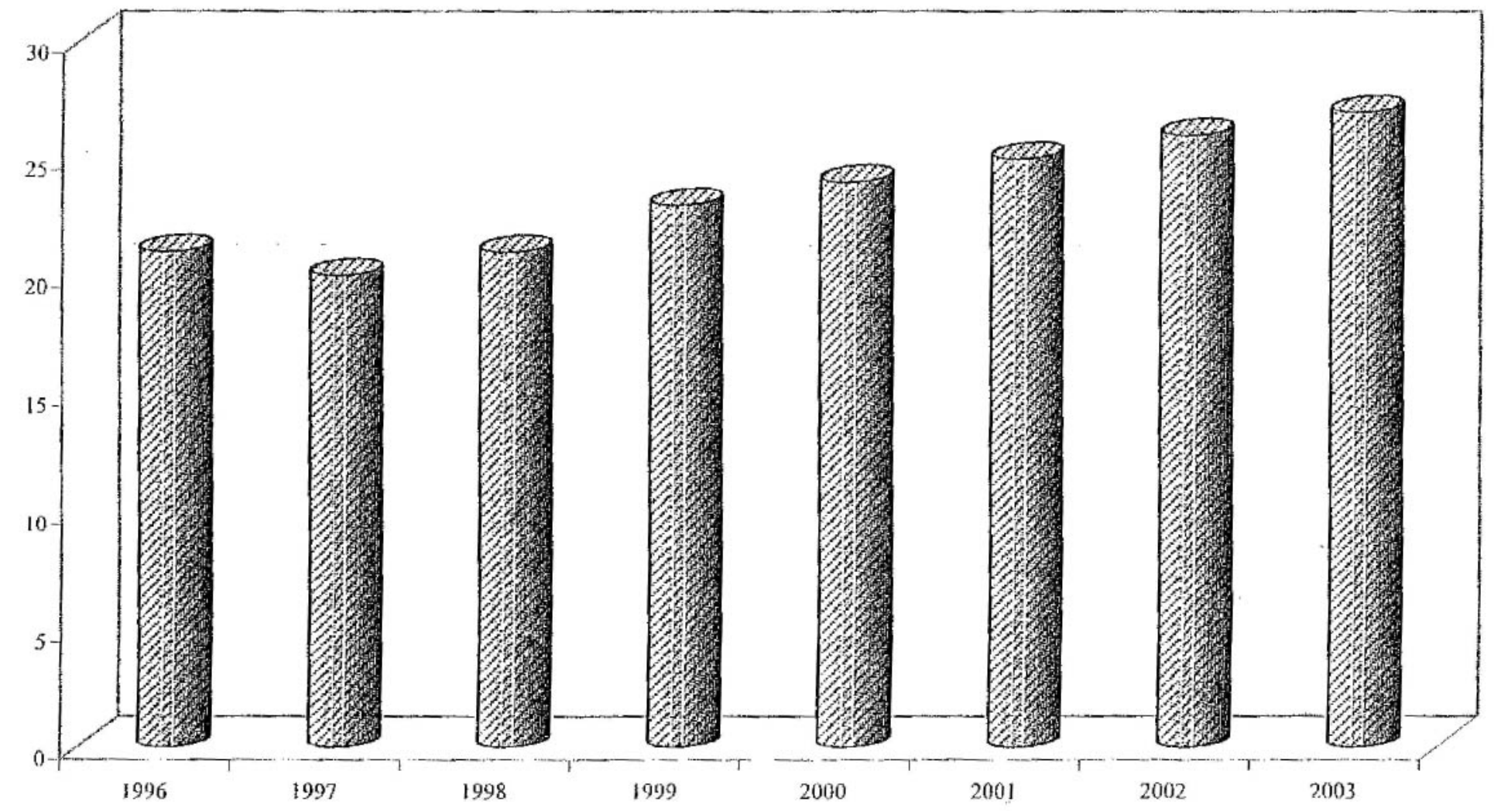

Source: Burkinabè anthonities; and Fund staff estimates. 
Figure 11. Burkina Faso: Share of Infants Vaccinated, 1996-2003 1/

(In percent)

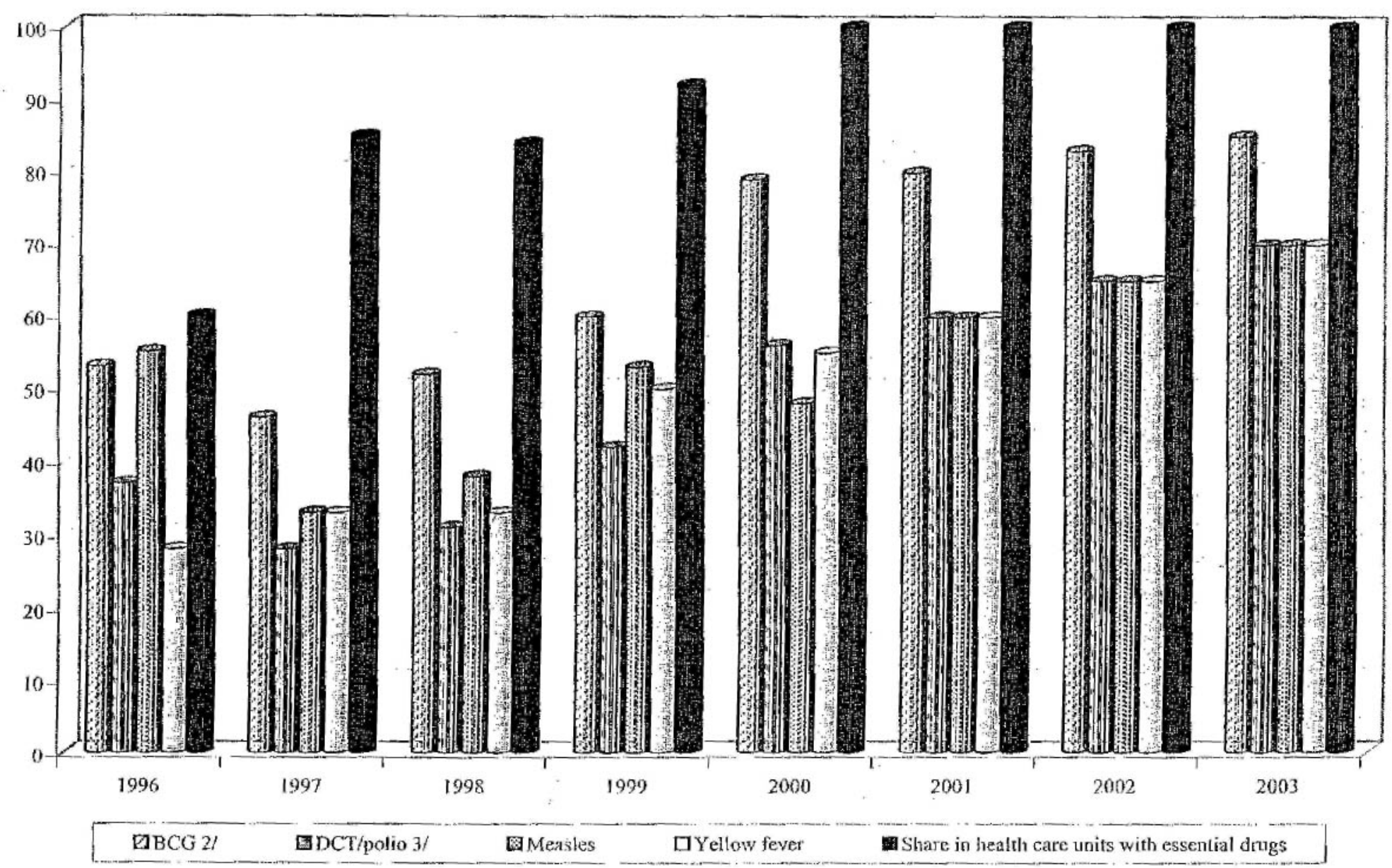

Sources: Burkinabè authorities; and Fund staff estimates.

$1 /$ Infants $(0-11$ months $)$.

2) Tuberculosis.

3/ Diphtheria, chalern, and letanus/polio. 
Tabic 1. Butkina Fáso: Fund Position, July 2005 - Deccmbcr 2005

\begin{tabular}{|c|c|c|c|c|c|c|c|c|c|c|c|c|c|c|c|c|c|c|c|}
\hline & \multirow{2}{*}{$\begin{array}{l}\text { Oulscanding } \\
\text { August } 31,2001\end{array}$} & \multirow{2}{*}{ Aug.-Sep. } & \multirow{2}{*}{ Oct.-Des. } & \multicolumn{4}{|c|}{2002} & \multicolumn{4}{|c|}{2003} & \multicolumn{4}{|c|}{2004} & \multicolumn{4}{|c|}{28015} \\
\hline & & & & Jan_-Mar. & Apr $-J_{\text {lan. }}$ & ful Sep. & Oell-Det. & Jan-Mas. & Apr.-Jun. & Jul.-\$cp. & Oeti-Dec. & Jan-Mar: & Apr.Juh. & lul,-Sep- & Del-Der. & JHa.-Mar. & Apr. - Surt. & Jul Sep. & Oet. Des. \\
\hline & \multicolumn{19}{|c|}{ (Millious of SDR) } \\
\hline Tuath trunsactions: (nel) & $\cdots$ & -0.96 & 1.08 & -0.96 & 1.08 & 3.95 & -4.52 & -2.29 & -4.50 & -229 & 4.21 & -2.95 & -4.25 & -2.07 & -4.90 & .2 .63 & -4.00 & -2.63 & -3.10 \\
\hline Disbarsenemens & $\ldots$ & $\ldots$ & 5.59 & $\ldots$ & 5.59 & 5.58 & & $\ldots$ & $\cdots$. & $\ldots$ & $\ldots$ & $\ldots$ & $\ldots$ & $\cdots$ & $\cdots$ & $\ldots$ & $\ldots$ & $\ldots$ & ... \\
\hline Reputrclasesfrepayntenls & $\ldots$ & $\ldots$ & $\ldots$ & $\ldots$ & $\ldots$ & $\ldots$ & $\ldots$ & $\ldots$ & $\ldots$ & $\ldots$ & ... & $\ldots$ & $\cdots$ & $\cdots$ & $\ldots$ & $\cdots$ & $\ldots$ & $\cdots$ & ... \\
\hline Repurchastes & $\ldots$ & $\cdots$ & $\cdots$ & $\cdots$ & $\cdots$ & $\cdots$ & & $\cdots$ & $\cdots$ & & ... & ... & $\cdots$ & $\ldots$ & ... & $\cdots$ & $\cdots$ & $\cdots$ & $\cdots$ \\
\hline \multirow{2}{*}{\multicolumn{20}{|c|}{$\begin{array}{l}\text { Finhanced Structural Adjustnicn! } \\
\text { Forility (ESAF)Poycrty Reduction }\end{array}$}} \\
\hline & & & & & & & & & & & & & & & & & & & \\
\hline and Growth Facility (PRGE) icpayme & $\ldots$ & 0.88 & 4.20 & 0.88 & 4.․․ㅁ & 9.55 & 4.20 & 2.21 & 4.20 & 2.21 & 3.98 & 2.87 & 3.98 & 1.99 & 4.64 & \pm .55 & 3.70 & 2.55 & 2.87 \\
\hline Charges and intercst & $\ldots$ & 0.08 & 0.31 & 0.08 & 0.31 & 0.08 & 0.32 & 0.08 & 0.30 & 0.08 & 0.29 & 0.08 & 0.27 & 0.08 & 0.26 & 0.68 & 0.24 & 0.08 & 0.23 \\
\hline Tonsl Fund eredit outstanding 1/ & 92.20 & 91.32 & 92.71 & 91.82 & 93.21 & $9 \%, 2.5$ & 93.05 & 90.84 & 86.64 & 84.43 & 80.45 & 77.58 & 73.60 & 77.61 & 66.97 & 64.42 & 60.67 & 58.12 & 55.24 \\
\hline \multicolumn{20}{|l|}{ Outsituditing parchasss } \\
\hline Wnder ESAEfPRGF & 92.20 & 91.32 & 92.71 & 91.82 & 39.21 & 97.25 & 93.05 & 97.84 & 86.64 & 84.43 & 80.45 & 77,58 & 73.60 & 71.61 & 66.97 & 64.42 & 601.157 & 58.12 & 55,24 \\
\hline \multicolumn{20}{|c|}{ (ln percerntage of quota, unless otlerwise indicaled) } \\
\hline Totsi Fund Eredit salstonding " & 153.16 & 151.69 & 15400 & 152.53 & 1.54 .84 & 161.54 & 154.56 & 850.89 & 143.92 & 140.25 & 133.64 & 128.87 & 122.26 & 118.96 & 111.25 & ro7.01 & 100.77 & 96.54 & 91.77 \\
\hline \multicolumn{20}{|l|}{ Outslanding purchloses } \\
\hline Under ESAE/PRGIF & 153.16 & 151.69 & 154.00 & 152.53 & 154.84 & 163.54 & 154.56 & 150.89 & 143.92 & 140.25 & 133.64 & 128.87 & 122.26 & [18.96 & 01.27 & $107.0 \mathrm{~s}$ & 100.7 & 96.54 & 91.7 \\
\hline \multicolumn{20}{|l|}{ Mcnorandum itcm: } \\
\hline Quova (in millions or.SUR:s) & 50.20 & 60.20 & 60.20 & 60.30 & 60.20 & 60.20 & 60.20 & 60.20 & 601.20 & $60.2 n$ & 60.20 & 60.20 & 60.30 & 69.20 & 60.20 & 60.20 & 60.20 & 00.20 & 60.20 \\
\hline
\end{tabular}

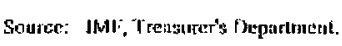

1) End oi preiod. 
Tabic 2. Furleine Fass: Seiected Economic and Finencial Fndicarors, 1995-2005

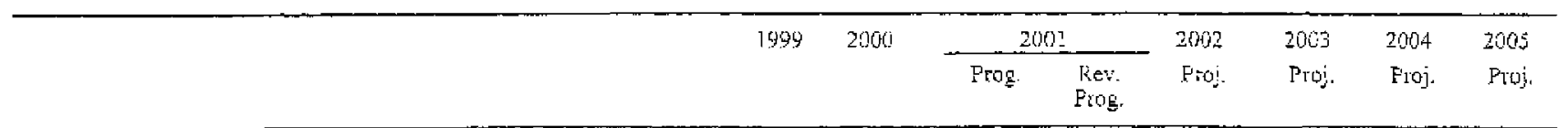

GD̃ axò prices

GDP a! constar:l prices

GDP denlato:

Consumet prices (annual average)

Consumer prices (ent of period.)

Morsy and credi!

Nol demestio assets (barking systelii) 1:

Credit to the goviertinatal 1

Credit to tile Erivate kectior a

Frost money (M2)

Voiscity (GDDMN2)

Exierinaj scctor

Fixports (t.s.t.: va'ued in CEA fiases)

lnports (T.u.': valuce in CEA itcucs)

Volume of expo:ts

Volma of impor's

Terons of tate

Real silective cainange rate (depreciation -j

Gross isvestmest

Gover:-17า:

Nongovemment sestor

Gross domestie sivings

Guver:3azen! savitegs

Nongovernment saving:

Gross natjonal savings

Contrat government thnat:ces

Tex revertuc

Donjestic antent expenditure

Orerali fiseal haiance, axcitiding grants

Ovealj fscal balancs, inciuting grancs

Basic bulaurce 2;

Excluding use of HIPC Injiative resources

Extersal sccto

Exports of goods and nonfactor scryices

Impors o[" gooda ard noníaclor services

C:arrent accoun bajance (excluditg curent official nassfexs)

Cunesh account bolance (includitg curent official ca:ssfars)

Fxteryal deint inzicators (before HJPC Iztitiative)

Dest-serviec ratio 3 i

T) èt-service ratio $4 /$

Gross ofticiai zeserves (in nuroths or inports)

Nominal stock ol public diot 5 ;

Nonina! GDP (in billions of CFA Ëants)

(Ainuaj percentage chinges, unless oricrorise spesitied)

\begin{tabular}{|c|c|c|c|c|c|c|c|}
\hline 6.3 & 2.2 & 6.3 & 62 & 5.8 & 5.7 & 5.5 & 5.5 \\
\hline-2.6 & 0.6 & 2.6 & 3.7 & 2.0 & 2.0 & 2.0 & 2.0 \\
\hline-1.1 & -0.2 & 2.9 & 3.0 & 2.0 & 2.0 & 2.0 & 2.0 \\
\hline 0.7 & 2.4 & 2.0 & 2.0 & 2.0 & 2.0 & 2.0 & 20 \\
\hline 5.6 & 8.3 & .. $\mathrm{s}$ & 6.2 & 4.2 & .2 & 4.9 & 6.2 \\
\hline 34 & 6.8 & -1.1 & 0.7 & -0.8 & -3.4 & 0.5 & 0.4 \\
\hline 1.5 & 8.1 & 5.6 & 5.2 & 5.0 & 4.6 & 4.4 & 5.9 \\
\hline $3 . !$ & -1.4 & 7.8 & 6.2 & 8.0 & $\mathrm{i} . .0$ & 11.0 & $\therefore .6$ \\
\hline 3.9 & 4.7 & 4.0 & 4.2 & 4.2 & $\frac{1}{4} .1$ & 4,0 & 3.8 \\
\hline - 88.0 & -6.3 & 20.0 & 20.9 & 13.1 & 7.8 & $9 . ?$ & 6.8 \\
\hline-4.5 & 3.1 & 5.5 & 10.6 & -3.2 & 2.4 & 4.3 & 5.3 \\
\hline تَا.كا2 & -11.6 & 13.4 & 7.3 & 26.1 & $\$ .5$ & 5.6 & 4.9 \\
\hline .8 .3 & -13.6 & 6.4 & 6.2 & 4.2 & 2.5 & 30 & 3.9 \\
\hline$\therefore 9$ & $-i 1.2$ & $5 . \bar{j}$ & 8.1 & -3.4 & 4.2 & 20 & 0.5 \\
\hline-2.0 & $-5 . i$ & $\ldots$ & $\ldots$ & $\ldots$ & $\ldots$ & .. & \\
\hline
\end{tabular}

(in parcent of GD?, uniess otherwise specified)

$\begin{array}{rrrrrrrr}27.1 & 27.6 & 27.4 & 2 \times .6 & 27.3 & 27.5 & 27.7 & 28.1 \\ 17.0 & 15.6 & 15.6 & 15.7 & 25.2 & 10.4 & 13.9 & 13.6 \\ 19.2 & 12.6 & 11.8 & 12.9 & 12.2 & 13.1 & 13.9 & 14.5 \\ 9.2 & 8.7 & 10.2 & 10.5 & 12.6 & 14.0 & 13.2 & 16.0 \\ 8.5 & 6.6 & 8.1 & 6.8 & 7.5 & 8.9 & 8.5 & 8.9 \\ 0.7 & 2.1 & 2.1 & 3.7 & 5.0 & 6.0 & 6.7 & 7.2 \\ 14.3 & 13.2 & 14.2 & 14.6 & 16.8 & 18.4 & 19.8 & 20.7\end{array}$

$+4.5$

11.9
-13.3

$-13.3$

$-4.0$

$-5.7$

\section{0}

12.5

$-17.7$

$$
-4.3
$$

$-2.1$

$-\mathbf{i} .6$

\section{5}

13.5

.13 .4

$-5.0$

$-2.7$

$-1.4$

11.6

29.6

50.7

29.6

$-16.0 \quad-17.9$

$-2.8 \quad-543$

11.7

25.0

$-16.8$

$-13.2$

14.0

$: 28$

-

$-5 .:$

$-2.9$

$-1.4$

14.5

12.5

$-12.1$

$-3.9$

$-2.3$

$-1.0$

14.7

12.2

$-10.8$

$-3.7$

$-2.3$

$-1.0$

$14.9 \quad 15 . \mathrm{j}$

1.8 11.5

$-9.7 \quad-9.2$

$-3.3 \quad-3.2$

$\begin{array}{ll}-2.2 & -2.2 \\ -0.3 & -0.9\end{array}$

$11.6 \quad 12.1 \quad 12.1 \quad 12.2 \quad$ i2.?

$\begin{array}{lllll}29.7 & 26.8 & 25.5 & 24.7 & 24.2\end{array}$

$\begin{array}{rrrrr}-17.7 & -14.6 & -13.0 & -11.7 & -17.5 \\ -j 4.0 & -10.4 & -3.1 & -7.9 & -7.4\end{array}$

$20.7 \quad 24.4$

i5.4 $\$ 8.6$

$5.2 \quad 4.4$

60.5

1,513

1,561

$1,7 ! 4$

1.719

1.857

2,001

$\begin{array}{llllll}27.8 & 20.0 & 19.9 & 17.1 & -7.0 & 15.9 \\ 20.9 & 15.7 & 15.6 & 13.2 & 13.2 & 13.0\end{array}$

$\begin{array}{llllll}27.8 & 20.0 & 19.9 & 17.1 & -7.0 & 15.9 \\ 20.9 & 15.7 & 15.6 & 13.2 & 13.2 & 13.0\end{array}$

4.6

...

$\cdots$

$\cdots$

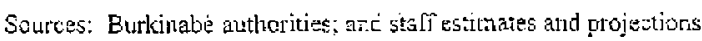

li in perceint of beginging-of-jeriod brcad money.

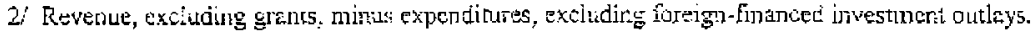

3) in percent of exporis of goods and nonactor services.

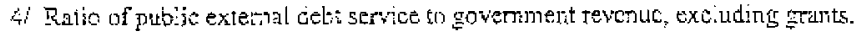

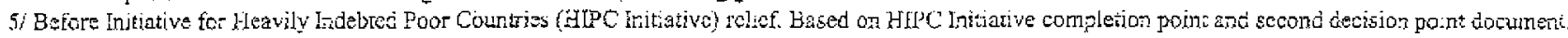

(E135/00;13; 6:-901) 
$-34-$

Table 3. Burkina Faso: Consolidated Qperations of the Central Governunert, 1999-2nos

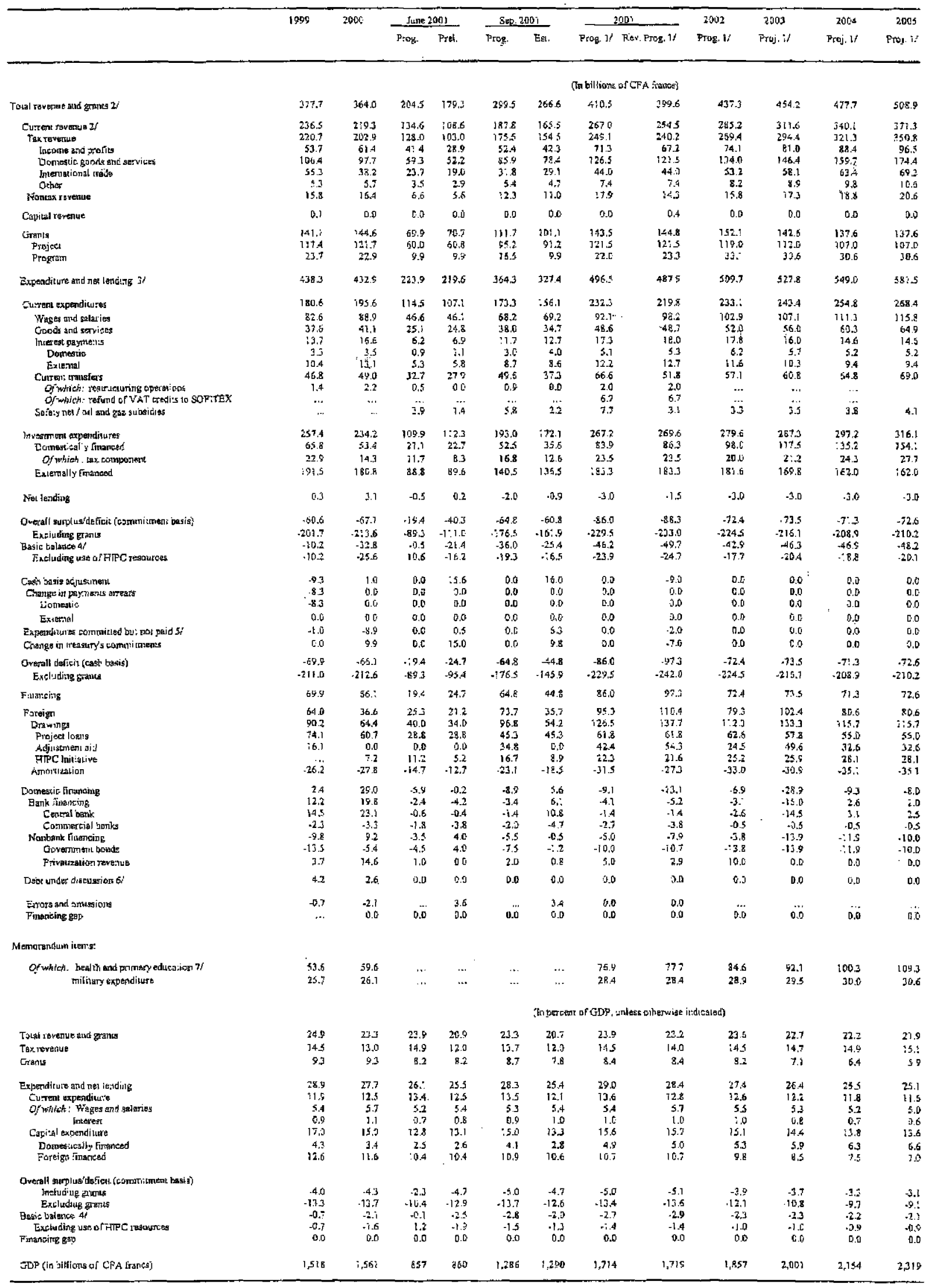

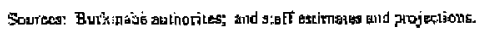

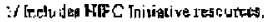

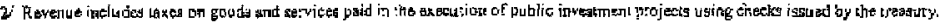

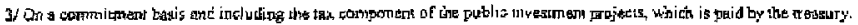

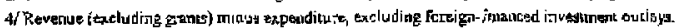

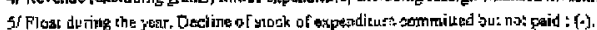

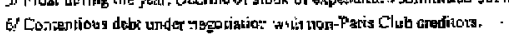

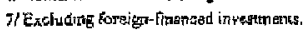


Table 4. Burkina Faso: Fiscal Inpact of the HIPC Initiative, 2000-05

(In billions of CFA francs, unless otherw:se specified)

2000

2002

Proj.

Initiative for Heavily Indebted Poor Countries (HIPC Initiative) assistance given

A. Interest due before HIPC Initiative assistance

B. Interest paid before HIPC Initiative assistance

C. HLC Initiative assistance on interest

(as a result of stock-of-debt operation only)

D. Interest due after HIPC Initiative assistance

E. Amortization due before HEC Initiative assistance

F. Amortization paid before HIPC Intiative assistance

G. HIPC Initiative assistance on amortization

(as a result of stock-of-dcbt operation only)

H. Amortization due after HIPC Initiative assistance

1. HIPC Initiative assistance provided as grants

(to cover debt serwice due)

J. HIPC Initjatjve assistance as exceptional financing

(to cover debt service due)

Total HIPC Initjative assistance $(\mathrm{C}+\mathrm{G}+\mathrm{l}+\mathrm{J})$

Total HIPC Initiative assistance (in millions of U.S. doflars)

Net cash flow to the budget from HIPC Initiative assistance $(\mathrm{B}+\mathrm{F}-(\mathrm{D}+\mathrm{H}-\mathrm{I}-\mathrm{J}))$

Memorandum items:

Other donor flows

Total net external flow's

(net external financing less debt service due)

Poverty reduction government expenditures ${ }^{1}$

Baseline pre-HIPC Initiative assistance expenditure projections

Post-HIPC Initiative assistance expenditure projections

Memorandum items:

Tax revenue (in percent of GDP)

Overall fiscal balance before HIPC Initiative assistance

(in percent of GDP)

Overall fiscal balance after HLPC Initiative assistance

(in percent of GDP)

\begin{tabular}{|c|c|c|c|c|c|}
\hline 13.1 & 12.7 & 11.6 & 10.3 & 9.4 & 9.4 \\
\hline 13.1 & 12.7 & 11.6 & 10.3 & 9.4 & 9.4 \\
\hline 0.0 & 0.0 & 0.0 & 0.0 & 0.0 & 0.0 \\
\hline 13.1 & 12.7 & 11.6 & 10.3 & 9.4 & 9.4 \\
\hline 27.8 & 27.3 & 33.0 & 30.9 & $35:$ & 35.1 \\
\hline 27.8 & 27.3 & 33.0 & 30.9 & 35. & 35.1 \\
\hline 0.0 & 0.0 & 0.0 & 0.0 & 0.0 & 0.0 \\
\hline 27.8 & 27.3 & 33.0 & 30.9 & 35.1 & 35,1 \\
\hline 0.0 & 0.0 & 0.0 & 0.0 & 0.0 & 0.0 \\
\hline 7.2 & 21.6 & 25.2 & 25.9 & 28.1 & 28.1 \\
\hline 7.2 & 21.6 & 25.2 & 25.9 & 28.1 & 28.1 \\
\hline 10.1 & 28.7 & 36.0 & 37.0 & 40.1 & 40.1 \\
\hline 7.2 & 21.6 & 25.2 & 25.9 & 28.1 & 28.1 \\
\hline 205.3 & 260.9 & 239.2 & 250.0 & 225.2 & 225.2 \\
\hline 164. & 220.9 & 194.6 & 208.8 & 180.7 & 180.7 \\
\hline
\end{tabular}

$\begin{array}{llllll}52.4 & 56.1 & 59.4 & 66.2 & 72.2 & 81.2\end{array}$

$\begin{array}{llllll}59.6 & 77.7 & 84.6 & 92.1 & 100.3 & 109.3\end{array}$

$\begin{array}{llllll}13.0 & 14.0 & 14.5 & 14.7 & 14.9 & 15.1 \\ -4.8 & -5.4 & -5.3 & -5.0 & -4.6 & -4.3 \\ -4.3 & -5.1 & -3.9 & -3.7 & -3.3 & -3.1\end{array}$

Sources: Burkinabè authorities; and Fund staff estimates and projections.

'Excludes foreign-financed investment. 
Table 5. Burkira Faso: Expenditures Financed by HIPC Initialive Resources, 2000-02

(In thousands of CFA francs)

\begin{tabular}{|c|c|c|c|}
\hline & 2000 & 2001 & 2002 \\
\hline Health & $2,514,605$ & $9,350,000$ & $9,878,400$ \\
\hline Wages and Salaries (basis health centers) & 102,983 & 660,000 & \\
\hline Expenditure on goods and services & 952,372 & $5, \div 49,226$ & \\
\hline Purchase of generic dugs & & 295,000 & \\
\hline Purchase of vaccines & 149,772 & 800,000 & \\
\hline Strengthening of operational capacities of the Ministry of Health & 374,735 & & \\
\hline Fight against diseases and lack of micronutriments : & $\ldots$ & $2,745,000$ & \\
\hline Training of staff & $\ldots$ & 199,226 & \\
\hline Strengthening of the national sanitary information system & $\ldots$ & 80,000 & \\
\hline Family pianning & $\ldots$ & $1,000,000$ & \\
\hline Primary care & $\ldots$ & 330,000 & \\
\hline Liquidation of 1999 corrmitments & 427,865 & $\ldots$ & \\
\hline Investments and Capital Transfers & $1,459,250$ & $3,240,774$ & \\
\hline Building of Basic Health Centers & - & $2,710,774$ & \\
\hline Equipment for Basis Health Centers & $1,459,250$ & 530,000 & \\
\hline Basic Education and Literacy & $2,873,834$ & $9,850,000$ & $9,777,600$ \\
\hline Wages and Salary & 74,770 & & \\
\hline Expenditure on goods and services & 165,000 & $1,500,000$ & \\
\hline Purchase of food for school meals & & 750,000 & \\
\hline Purchase of educational material & 165,000 & 750,000 & \\
\hline Investments and Capital Transfers & $2,634,064$ & $8,350,000$ & \\
\hline Building and repair of schools & $2,343,064^{--}$ & $3,620,000$ & \\
\hline Equipment of schools & $29 ;, 000$ & 525,000 & \\
\hline Building of houses for teachers & $\ldots$ & $2,700,000$ & \\
\hline Building of literacy centers & $\ldots$ & 380,000 & \\
\hline Building of drillings & $\ldots$ & 975,000 & \\
\hline Building of latrines & $\cdots$ & 150,000 & \\
\hline Rural roads & $1,796,146$ & $2,350,000$ & $2,268,000$ \\
\hline Environment and water & - & 50,000 & 50,400 \\
\hline Agriculture & - & $2,150,000$ & $2,016,000$ \\
\hline Shallow-water development & & 800,000 & \\
\hline Purchase of seeds & & 450,000 & \\
\hline Support for producers & $=$ & 900,000 & \\
\hline Livestock & - & $1,250,000$ & $1,209,600$ \\
\hline Overall use of HTC Initiative Resources & $7,184,585$ & $25,000,000$ & $25,200,000$ \\
\hline
\end{tabular}

Sources: STC-PDES; Ministry of Econony and Finance; and staff estimates and projections. 
Table 6. Burkina Faso: Budgetary Expenditure in Social Sectors, 1996-2001

(Including HIPC Initiative Resources)

\begin{tabular}{|c|c|c|c|c|c|c|}
\hline & 1996 & 1997 & 1998 & 1999 & 20110 & $\begin{array}{l}2001 \\
\text { Proj. }\end{array}$ \\
\hline & \multicolumn{6}{|c|}{ (As a tercentage of total expenciiture) } \\
\hline Total social expenditure & 20.7 & 20.1 & 20.6 & 19.4 & 22.3 & 24.8 \\
\hline Current & 11.7 & 11.2 & 11.1 & 11.4 & 12.2 & 13.3 \\
\hline Capital & 9.0 & 8.9 & 9.5 & 7.9 & 10.0 & 11.5 \\
\hline Health & 11.3 & 9.5 & 9.6 & 9.1 & 9.4 & 9.6 \\
\hline Current expenditure & 4.8 & 4.5 & 4.6 & 4.6 & $\$ .0$ & 5.0 \\
\hline Capital expenditure & 6.5 & 4.9 & 5.0 & 4.5 & 4.4 & 4.6 \\
\hline Domestic resources & 0.4 & 0.4 & 1.0 & 1.0 & 1.1 & i.5 \\
\hline External expenditure & 6.1 & 4.5 & 4.0 & 3.6 & 3.3 & 3.3 \\
\hline Education & 8.5 & 10.0 & 10.3 & 9.4 & 11.0 & 12.7 \\
\hline Current expenditure & 6.1 & 6.1 & 5.8 & 6.1 & 6.5 & 7.2 \\
\hline Capital expexditure & 2.4 & 3.9 & 4.5 & 3.3 & 4.5 & 5.5 \\
\hline Domestic resources & 0.5 & 0.5 & 0.7 & 0.7 & 0.5 & 2.4 \\
\hline Exienal exponditure & 1.9 & 3.4 & 3.8 & 2.6 & 3.4 & 3.2 \\
\hline Women's welfare and other social expenditare & 0.9 & 0.7 & 0.7 & 0.8 & 0.8 & 1.5 \\
\hline Current expenditure & 0.7 & 0.5 & 0.6 & 0.7 & 0.7 & 1.1 \\
\hline Capital expenditure & 0.2 & 0.0 & 0.1 & 0.1 & 0,1 & 0.3 \\
\hline domestic resources & 0.2 & 0.0 & 0.1 & 0,1 & 0.1 & 0.3 \\
\hline extemal expenditare & 0.0 & 0.0 & 0.0 & 0.0 & 0.0 & 0.0 \\
\hline Rural rcads (capital) & 0.0 & 0.0 & 0.0 & 0.0 & 1.1 & 1.1 \\
\hline Domestic resoutces & 0.0 & 0.0 & 0.0 & 0.0 & 0.4 & 0.5 \\
\hline \multirow[t]{2}{*}{ Excemal fingls } & 0.0 & 0.0 & 0.0 & 0.0 & 0.7 & 0.6 \\
\hline & \multicolumn{6}{|c|}{ (As a priscentage of GDP) } \\
\hline Total social expenditure & 4.5 & 4.9 & 4.9 & 5.5 & 6.2 & 7.0 \\
\hline Current & 2.6 & 2.7 & 2.6 & 3.3 & 3.4 & 3.8 \\
\hline Capital & 2.0 & 2.2 & 2.3 & 2.3 & 2.8 & 3.3 \\
\hline Healith & 2.5 & 2.3 & 2.3 & 2.6 & 2.6 & 2.7 \\
\hline Current expenditure & 1.1 & 1.1 & 1.1 & 1.3 & 1.4 & 1.4 \\
\hline Capital expenditure & 1.4 & 1.2 & 1.2 & 1.3 & 1.2 & 1.3 \\
\hline Dumestio rescources & 0.3 & 0.1 & 0.2 & 0.3 & 0.3 & 0.4 \\
\hline External expenditure & 1.3 & 1.1 & 0.9 & 1.0 & 0.9 & 0.9 \\
\hline Education & 1.9 & 2.4 & 2.5 & 2.7 & 3.1 & 3.6 \\
\hline Current expenditure & 1.3 & 1.5 & 1.4 & 1.7 & 1.8 & 2.0 \\
\hline Capital expenditure & 0.5 & 1.0 & 1.1 & 0.9 & 1.3 & 1.6 \\
\hline Dorrcstic resulurces & 0.1 & 0.1 & 0.2 & 0.2 & 0.2 & 0.7 \\
\hline Exterzal expenditure & 0.4 & 0.8 & 0.9 & 0.8 & 0.9 & 0.9 \\
\hline Women's welfare and other social experditure & 0.2 & 0.2 & 0.2 & 0.2 & 0.2 & 0.4 \\
\hline Current expenditure & 02 & 0.1 & 0.1 & 0.2 & 0.2 & 0.3 \\
\hline Capital expenditure & 0.0 & 0.0 & 0.0 & 0.0 & 0.0 & 0.1 \\
\hline Domestic resources & 0.0 & 0.0 & 0.0 & 0.0 & 0.0 & 0.1 \\
\hline External expenditure & 0.0 & 0,0 & 0.0 & 0.0 & 0.0 & 0.0 \\
\hline Rutual roads (capital) & 0.0 & 0.0 & 0.0 & 0.0 & 0.3 & 0.3 \\
\hline Domestic resourcess & 0.0 & 0.0 & 0.0 & 0.0 & 0.1 & 0.1 \\
\hline Exremal funds & 13.0 & 0.0 & 0.0 & 0.0 & 0.2 & 0.2 \\
\hline
\end{tabular}

Sources: Miristry of Econorny and Finance; and staff estima and projections. 
Table 7. Burkint Faso: Balance of Paynents, 1999-2005

\begin{tabular}{|c|c|c|c|c|c|c|c|c|}
\hline & \multirow[t]{2}{*}{1999} & \multirow[t]{2}{*}{2000} & \multicolumn{2}{|c|}{2001} & 2002 & \multirow{2}{*}{\multicolumn{2}{|c|}{2003}} & \multirow[t]{2}{*}{2005} \\
\hline & & & Peog. & 0 . $1 /$ & & eclivens. is & & \\
\hline & \multicolumn{7}{|c|}{ (In billions o[ CEA frames] } & \\
\hline Exports, f.o.b. & 156.2 & 146.4 & 178.8 & 177.0 & 200.2 & 215.8 & 235.5 & 251.6 \\
\hline Or which: cotton & 836 & 72.4 & 94.1 & 35,6 & 1169 & 125.9 & 141.3 & 149.3 \\
\hline gold & 5.2 & 6.2 & 5.8 & 6.5 & 6.0 & 6.0 & 6.0 & 6.3 \\
\hline ituports, fo.b. & -357.4 & -368.6 & -396.9 & -403.5 & -394.5 & -404.1 & -421.6 & $-443 . \mathrm{T}$ \\
\hline of which aspital gerods & $-\$ 25.0$ & -122.8 & -138.9 & -141.6 & -135.0 & -127.8 & -124.3 & -124.3 \\
\hline Trade balance & -201.2 & -222.2 & -218.1 & -230.5 & -194.3 & -188.3 & -186.1 & -192.1 \\
\hline Services and income (net) & -82.0 & -86.5 & -91.0 & -93.9 & .91 .4 & -92.5 & $-9 \leq .5$ & -99.1 \\
\hline Services & .70 .8 & .72 .6 & -77.9 & -80.0 & -78.4 & -80.5 & -84.2 & -8.8 .2 \\
\hline Insone & -11.3 & -14.0 & $-13 . !$ & -13.9 & -13.0 & $-1 i .9$ & -11.3 & -10.9 \\
\hline Of which: inderest payments & -11.1 & $-i 3 . \varepsilon$ & -2.8 & -13.5 & $-\because 2.4$ & -1.1 & -10.2 & -9.5 \\
\hline or wisien: budget & -10.4 & -13.1 & -12.3 & .13 .7 & -21.6 & .10 .3 & -9.4 & -9.4 \\
\hline Cutrent trans $\{$ thro (not) & 88.7 & 85.2 & 82.3 & 84.2 & 92.3 & 98.6 & $1: 1.5$ & 119.6 \\
\hline Private & 39.7 & 29.9 & 20.3 & 20.1 & 149 & 20.3 & 20.4 & 33.4 \\
\hline Of whicis : workars' remiltanest (́́coss) & 50.3 & 41.0 & 30.0 & 30.0 & 24,0 & 28.4 & 36.4 & 35.3 \\
\hline Officiel & 48.9 & 55.3 & $E 2.1$ & 64.1 & 77.3 & 78.4 & 82.1 & 86.2 \\
\hline Of whicid: budegctary (program grants) & 23.7 & 22.9 & 22.0 & 23.3 & 33.1 & 30.6 & 30.6 & 30.6 \\
\hline Cuirent atcount (detieil= -) & -194.6 & $-2 \geq 33.5$ & -225.7 & $-240:$ & $-19 \bar{j} .3$ & -12.2 & -170.0 & .373 .6 \\
\hline Excluding currert official transfers & $-243,5$ & -278.8 & -283.8 & -304.3 & -270.7 & -260.6 & -252.2 & -257.8 \\
\hline Capital trans lats & 120.4 & 124.7 & 124.5 & $\$ 24.5$ & 122.0 & $115 !$ & 110.3 & 110.4 \\
\hline Project granls & 117.4 & 121.7 & 121.5 & 121.5 & 119.0 & 112.0 & 107.0 & 107.0 \\
\hline Ouluce eapilal transfers & 3.0 & 3.0 & 3.0 & 3.0 & 3.0 & 3.1 & 3.3 & 3.4 \\
\hline Financial operaliuns & 65.5 & 51.6 & 85.3 & 94.8 & 61.5 & 84.5 & 61.3 & 62.2 \\
\hline Ofticial capilal & 64.0 & 29.4 & 70.4 & $8 \in 4$ & 52.4 & 74,7 & 50.7 & 50.8 \\
\hline Disbursements & 90.2 & 60.7 & 104.2 & 116.1 & 87.1 & 107.4 & 87.6 & 87.6 \\
\hline Project loans & 74.2 & 60.7 & 61.8 & $6[.8$ & 62.5 & 578 & 55.0 & 55,0 \\
\hline Progran loans & 26.1 & 0.0 & 42,4 & 54.3 & 24.5 & 49.6 & 32.6 & 32.6 \\
\hline Anvorlizalion & -26.2 & -31.3 & -33.8 & -29.7 & -34.7 & -32.7 & -36.9 & -36.8 \\
\hline Of which: budget & -26.2 & -27.8 & -31.5 & -27.3 & -33.0 & -30.9 & -35.1 & -35.1 \\
\hline Private snpilal $2 t$ & 5.4 & 22.2 & 54.8 & 8.4 & 9.1 & 9.8 & 10.5 & 13.4 \\
\hline Errors and orrissions & -8.6 & 6.9 & 0.0 & 0.0 & 0.0 & 0.0 & 0.0 & 0.5 \\
\hline Ouerall balance & -13.3 & $-40,3$ & -17.1 & -20.9 & -9.9 & 17.4 & 1.5 & 1.0 \\
\hline Finauging & 13.3 & 40.3 & 17.1 & 20.9 & 9.9 & -17.4 & -1.6 & -1.0 \\
\hline Net foreign assets & 9.1 & 30.5 & -5.2 & -0.7 & -15.3 & -4.3 .3 & -29.7 & -29.1 \\
\hline Net official reserves & 21.5 & 28.7 & $-5,2$ & -0.7 & -15.3 & -43.3 & -29.7 & $-29 . \mathrm{J}$ \\
\hline gross official resterves & 14.6 & 30.5 & -11.2 & $-7,0$ & $-15,6$ & -32.2 & .17 .8 & -18.8 \\
\hline $\operatorname{IMF}(x \mathrm{x})$ & 70 & -1.7 & 6.1 & 6.3 & 0.3 & -11.1 & $-1] .9$ & -10.3 \\
\hline Lise of tesources & 10.3 & 5.2 & 15,3 & $: 29$ & 9.8 & 0.0 & 0.0 & 0.0 \\
\hline Reprymenls & -3.3 & .7 .0 & -9.3 & -9.6 & -9.5 & -11.1 & -11.9 & -10.3 \\
\hline Net foreign assets, conumerciat banks & -12.4 & 1.7 & 0.0 & 0.0 & 0.0 & 0.0 & 0.0 & 0.9 \\
\hline Change in arrears (redustions -j) & 0.0 & 0.0 & 0.0 & 0.0 & 0.0 & 0.0 & 0.0 & 0.0 \\
\hline HiPC Inilialive & 0.0 & 7.2 & 22,3 & 21.6 & 25.2 & 25.9 & 28.1 & 28.1 \\
\hline Dejt under discussion if & 4.2 & 2.6 & 0.0 & 0.0 & 0.0 & 0,0 & 0.0 & 0,0 \\
\hline Fittancing gap & 0.0 & 0.0 & 0.9 & 0.0 & CO & 0.0 & 0.0 & 0.0 \\
\hline Memorgaturn ilems: & & & percent of $G$ & nless other & se indscated) & & & \\
\hline Tride bnianted (deficil=-) & -13.3 & -14.2 & -12.7 & -13.4 & -10.5 & -9.4 & -8.6 & -8.3 \\
\hline Cottor export valume (thousands of mentie lonis) & 114.7 & 108.5 & 112.9 & $1: 3.8$ & 164.6 & 172.9 & 381.1 & $: 85.2$ \\
\hline Curreht necesunt (dusicitz-) & -12.8 & $-i 4.3$ & -13.2 & -14.0 & $.10,4$ & -9.1 & -7.3 & $-7,4$ \\
\hline Excluding current oficial transîts & -16.0 & -17.9 & -16.8 & -17.7 & -14.6 & -73.0 & .11 .7 & -11.1 \\
\hline Overall balanese (deflicit= -) & -0.9 & -2.6 & -1.0 & -1.2 & -0.5 & 0.9 & 0.1 & 0.0 \\
\hline Tolal debi-scrvice ratio $4 /$ & 33.0 & 31.1 & 27.8 & 25.5 & 25.3 & 22.7 & $2 \geq 4$ & 20,7 \\
\hline Debl-service ralio (ratic to goveriment revenue) & 10.5 & 16.5 & 20.9 & 15.6 & 13.9 & 12.3 & 12.1 & 10.7 \\
\hline Gross international neserves (in billions of CFAF) & 92.2 & 171.3 & & 178.3 & 193.9 & 226.1 & 243.9 & 262.7 \\
\hline In moriths of goods, c i.t. & 5.5 & 4.8 & & 4.5 & 5.0 & 5.7 & 5.9 & 6.1 \\
\hline in months of guods and nanfactor services & 5.1 & 44 & & 4.2 & 4.7 & 5.3 & 5.5 & 5.6 \\
\hline GDP at cirrent prices (in billions or CFAF) & 1,518 & 1,561 & 1,714 & 1,719 & 1.857 & 2,001 & 2,154 & 2,319 \\
\hline
\end{tabular}

Sofkrescs: Central Ezzk of West Africen States (BCEAO), and stafle estimates and projections.

1/ Based on lates! Worta Ecoronic Outlaok projections (WEO)

2) Inchudes port ralio investoren! and foreign direot investment.

3i Contentious delst in negotiation with non-Patis Club arediters.

$4 i$ In percent of exports of goods and tonlexior bervicess. 
Tabie \&. Rurkina Faso: 'l'racking Delivery of IIIPC: Initiative Assistanci

(As of Seplember 30, 2001)

\begin{tabular}{|c|c|c|c|c|c|c|}
\hline & \multicolumn{2}{|c|}{ Original } & \multicolumn{4}{|c|}{ Entianced } \\
\hline & $\begin{array}{l}\text { Agreement to } \\
\text { provide HITC } \\
\text { relief? }\end{array}$ & $\begin{array}{l}\text { Delivery of } \\
\text { comp point } \\
\text { assistance begun? }\end{array}$ & $\begin{array}{l}\text { Agreement to } \\
\text { provide } \mathrm{H}^{\mathrm{P}} \mathrm{C} \\
\text { relief? }\end{array}$ & $\begin{array}{l}\text { Agreement to } \\
\text { provide interim } \\
\text { assistance? }\end{array}$ & $\begin{array}{l}\text { Delibery of } \\
\text { interim } \\
\text { assistance begun? }\end{array}$ & $\begin{array}{l}\text { Delibery of } \\
\text { comp.point } \\
\text { assistance begun? }\end{array}$ \\
\hline Multilatcral creditors & & & & & & not reached \\
\hline MF & yes & yes & yes & yes & yes & \\
\hline $\mathrm{IDA}$ & yes & yes & yes & yes & yes & \\
\hline AIDB/AJDF & yes & yes & yes & yes & yes & \\
\hline IFAD & yes & yes & $y e s$ & yes & yes & \\
\hline $\mathrm{EU}$ & Jimited & no & yes & no & no & \\
\hline OPEC Fund & yes & nol yet & yes & pending $1 /$ & no & \\
\hline BADEA & limited & yes & yes & periding $1 /$ & no & \\
\hline ECOWAS & no & no & no & no & по & \\
\hline FEGECE & $\mathrm{n} / \mathrm{a}$ & verify & no & no & по & \\
\hline BOAD & yes & yes & yes & yes & yes & \\
\hline Isiamic Development Bank & limited & yes & yes & limited & 'ño & \\
\hline \multicolumn{7}{|l|}{ Paris Club creditors } \\
\hline Austria & yes & yes & yes & yes & yes & \\
\hline Russia & yes & yes & yes & yes & yes & \\
\hline France 21 & yes & yes & yes & yes & yes & \\
\hline Italy $2 i$ & yes & yes & yes & yes & yes & \\
\hline Netherlands $3 /$ & yes & yes & yes & yes & yes & \\
\hline Spain 2/ & yes & yes & yes & yes & yes: & \\
\hline United Kingdonn & yes & yes & yes & yes & yes & \\
\hline \multicolumn{7}{|l|}{ Non-Paris Club bilateral creditors } \\
\hline Algeria & no & no & no & no & no & \\
\hline China & no & no & no & no & no & \\
\hline Kuwait 4/ & no & no & yes: & pendirg $1 /$ & no & \\
\hline Saudi Arabia & no & no & pending & pending & pending & \\
\hline Libya & no & no & no & no & no & \\
\hline Taiwan Province of China & no & no & no & no & no & \\
\hline Côte d'Ivoire & no & no & no & no & IIO & \\
\hline \multicolumn{7}{|l|}{ Coonmercial Creditors } \\
\hline Insigni licant & & not offered & & & & not oflered \\
\hline
\end{tabular}

Sources: Burkinabe authorities and staff estimates.

1/ Pending until conpletion point.

2/ Bilateral agreements not yet concluded.

3/ The Netherlands is providing 100 percent relief, including on its commercial debt.

4/ The Kuwait Fund for Arab Economic Development is considering providing 100 pereent debt relic on pre-cutoff-date oflycial development assistantce loans

in line witl similar initiatives from Paris Club nembers.

$$
\text { CInternational Monetary Fund. Not for Redistribution }
$$


Table 9. Durkina liaso: Monetary Survey, 1999 - 2005

\begin{tabular}{|c|c|c|c|c|c|c|c|c|c|c|c|c|c|c|c|c|c|c|}
\hline & \multirow{3}{*}{$\begin{array}{l}1999 \\
\text { Dec. }\end{array}$} & \multicolumn{4}{|c|}{2000} & \multicolumn{6}{|c|}{2001} & \multicolumn{3}{|c|}{20002} & \multirow[b]{2}{*}{ Doo. } & \multirow{3}{*}{$\begin{array}{l}2003 \\
\text { Dec: }\end{array}$} & \multirow{3}{*}{$\begin{array}{r}2904 \\
\text { Der. } \\
\text { ojections }\end{array}$} & \multirow{3}{*}{$\begin{array}{l}2005 \\
\text { Des: }\end{array}$} \\
\hline & & \multirow{2}{*}{ Martb } & \multirow[t]{2}{*}{ sure } & \multirow[t]{2}{*}{ Sep. } & \multirow[t]{2}{*}{ Dec } & \multirow[t]{2}{*}{ March } & \multirow[t]{2}{*}{ Marsoly } & \multicolumn{2}{|c|}{ Jene } & \multirow{2}{*}{\multicolumn{2}{|c|}{$\frac{\text { Sep Dec. }}{\text { Prujections }}$}} & Musch & Junc. & Sep. & & & & \\
\hline & & & & & & & & Prog. & Real. & & & \multicolumn{4}{|c|}{ Prujectiuns } & & & \\
\hline & \multicolumn{18}{|c|}{ (lis bilitins or CFA tiantes) } \\
\hline Nel forctigra assetit & 163.5 & 171.3 & 144.8 & 128.2 & 125.8 & 124.6 & 128.2 & 124.6 & 125.4 & 191.0 & 126.5 & $3 \times 6.4$ & 127.1 & 126.4 & 141.8 & 185.1 & 214.7 & 243.8 \\
\hline Cerlral Barle of West ABjictun States (BCEAO) i & 91.6 & 89.8 & 62.8 & 47.2 & 54.1 & 5.5 .5 & 60.5 & 54.5 & 67.9 & 49.3 & 51.8 & 54.7 & 55.4 & 54.7 & 20.1 & $: 16.4$ & 143.0 & 172.1 \\
\hline Asserts & 192.2 & 192.0 & 175.7 & 163.4 & 171.3 & 175.8 & 173.8 & $\$ 77.7$ & 178.7 & 167.7 & 178.3 & 154.6 & 151.6 & 154.9 & 193.9 & $22 \dot{6} .1$ & 243.9 & $26,2.7$ \\
\hline Liabilities & -100.5 & -102.1 & -112.9 & -116.8 & -117.2 & -121.3 & -113.3 & .123 .2 & .110 .9 & -118.4 & .923 .5 & -99.9 & .99 .1 & $-100,2$ & -123.8 & .112 .7 & -100.9 & -10.7 \\
\hline Connnerrin banks $t 7$ & $7 \$ .9$ & 81.5 & 82.0 & 80.9 & 71.7 & 70.1 & 67.7 & 70.1 & 57,6 & 71.7 & 71.7 & 76.7 & 76.7 & 71.7 & 71.7 & 71.7 & 71.7 & 11.7 \\
\hline Nel dnmestic assets & 225.3 & 249.3 & 259.4 & 274.0 & 257.7 & 302.5 & 271.2 & .297 .6 & 262.7 & 374.4 & 281.5 & 298.2 & 284.5 & 292.6 & 298.8 & 304.0 & $32 B .11$ & 361.9 \\
\hline Ret domestic oredit & 237.0 & 275.6 & 269.1 & 282,4 & 294.9 & 314.9 & 304.6 & 305.0 & 298.9 & 311.1 & 318.1 & 334.9 & 321.2 & 329.2 & 3.15 .5 & 340.5 & 364.6 & 398.5 \\
\hline Nel crellat bo gavernment & 49.8 & 68.2 & 73,3 & 78.9 & 76.1 & 79.8 & 79.8 & 74.7 & 80.8 & 366.7 & 78.6 & 78.6 & 78.5 & 76.4 & 35.5 & 60.19 & 63.69 & 6.109 \\
\hline Trezsowy & 93.9 & 107.7 & 112.1 & 117.2 & 113.3 & 117.4 & 117.4 & IIIA & 109.6 & 119.9 & 108.5 & 108.5 & 108.5 & 100.3 & 105.4 & 90.4 & 93.6 & 45.0 \\
\hline BCEAU & 60.4 & 74.1 & 81.0 & 89.5 & 83.5 & 89.8 & 89.8 & 83.6 & 83.1 & 94.3 & 82.1 & $82: 1$ & 82.1 & 79.9 & 79.6 & 65.1 & 68.3 & 70.7 \\
\hline Commercial hanks & 33.6 & 33.6 & 31.1 & 27.7 & 30.2 & 27.6 & 27.6 & 27.7 & 26.4 & 25.6 & 26.4 & 26.4 & 26.4 & 26,4 & 25.9 & 25.4 & 24.2 & 24.4 \\
\hline Odvet central govemnuent &.$\$ 1.2$ & -395 & -38.8 & -38.4 & -37.6 & -53.4 & -37.6 & -36.7 & .28 .8 & $.33,2$ & .29 .9 & -29.9 & -29.9 & .29 .9 & -29.9 & -29.9 & -299 & -29.9 \\
\hline Of which; project depusits & .23 .3 & -23.7 & 24.8 & .24 .0 & -18.6 & 17.9 & .17 .9 & -227 & -17.2 & -21.8 & -17.2 & .17 .2 & -17.2 & .17 .2 & -47.2 & -17.2 & -17.2 & -17.2 \\
\hline Credil to the teonomy & 187.2 & 2017.4 & 1964 & 203.5 & 218.8 & 235.1 & 229.8 & 230.3 & 218.1 & 224.4 & 209.6 & 256.3 & 242.7 & 252.9 & 2600.0 & 280.2 & 301.6 & 333.4 \\
\hline Or writicf: crup credst & 16.3 & 39.0 & 29.5 & 160 & 38.5 & 40.0 & 40.0 & $30: 0$ & 35.01 & 10.0 & 250 & 35.0 & 35.10 & 15.7 & $2 \pi .1$ & 29.2 & 31.5 & 348 \\
\hline Other ilems (net) & -11.8 & -26.3 & -10.2 & $-8,4$ & -37.1 & -12.4 & -38.4 & -92.4 & -36.7 & -36.7 & -36.7 & -36.7 & -36.7 & -36.7 & -36.7 & -36.7 & -36.7 & -36.7 \\
\hline Broad nomey & 388.6 & 420.6. 6 & 404.2 & 402,2 & 383.5 & $42 \%(1)$ & 399.1 & 417.2 & 387.7 & 395.2 & 407.9 & $4: 4.6$ & 411.7 & 419.0 & $\$ 40.6$ & 4850 & 542.6 & 605.6 \\
\hline Of which : currency in circulatton & 142.6 & 144.3 & 135.15 & 130.8 & 136.1 & 142.1 & 172.4 & 13.5 .4 & 1921 & 131.1 & 122.1 & 143.0 & 142.8 & 141.6 & 131.9 & 145.3 & I62.4 & 181.2 \\
\hline Mengurandunn ilems: & \multicolumn{18}{|c|}{ 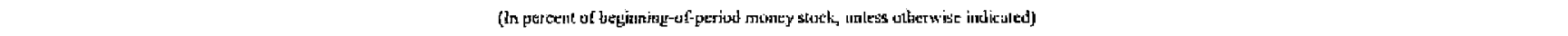 } \\
\hline Nel fereign assels & -2.4 & 2.0 & $-4,8$ & -9.1 & -9.7 & 10.0 & 0.6 & 0.3 & $-(1.1 .1$ & -1.2 & 0.2 & D. B & 0.2 & 0.0 & 3.7 & 9.8 & 6.1 & 5.4 \\
\hline Nêt tbomestic assels & 5.0 & 6.2 & 8.8 & 12.5 & 8.3 & s.o & 3.5 & 9.1 & 1,2 & 4.4 & 0.2 & 4.1 & 0.8 & 2.7 & 4.3 & 5.2 & 4.9 & 6.2 \\
\hline Net eredil os grovenument & 3.4 & 4.7 & 6.0 & 7.5 & 6.8 & -0.1 & 1.0 & -04 & 1.2 & 2.8 & 0.6 & 0.0 & 0.0 & -0.5 & 0.8 & .3 .4 & 0.5 & 0.4 \\
\hline Crestil to the ecentumy & 1.9 & $5 \%$ & 2.4 & 4.2 & 8.1 & 4.4 & 2.9 & 3.0 & -0.2 & 1.5 & 5.4 & 4.1 & 0.8 & 3.3 & 5.0 & 4.6 & 4.4 & 5.9 \\
\hline (annutul percenninge change) & 3.9 & 10 & 4.9 & 8.7 & 16.8 & 8.3 & 5.0 & 5.3 & -0.3 & 2.6 & 9.5 & 70 & 1.9 & 5.6 & 8.5 & 7.8 & 7.6 & 10.6 \\
\hline Money supply & 3.1 & B. 2 & 4.0 & 3.5 & -1.4 & 50 & 4.2 & 8.8 & 1.1 & 3.1 & 6.4 & 4.1 & 19.9 & 2.7 & 8.0 & 11.0 & 11.0 & 11.6 \\
\hline Currency velarily (GDPhorond merey) & 3.9 & & & & 4.1 & & & & & & 4.2 & & & & 4.2 & 4.1 & $4 . n$ & 3.8 \\
\hline
\end{tabular}

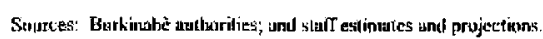

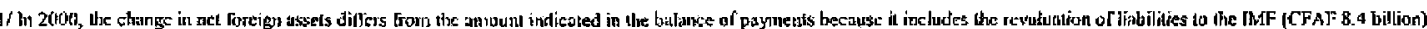

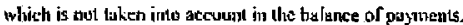


Table 10. Burkina Faso: Privatization Program

(In billions of CFA francs, unless otherwise specified)

\begin{tabular}{|c|c|c|c|c|c|c|c|c|c|c|}
\hline Enterprises & Sector & $\begin{array}{l}\text { Percesllage Cap } \\
\text { Held by } \\
\text { Covernownol }\end{array}$ & Capilal & $\begin{array}{l}\text { Cap. Jeld by } \\
\text { Ginverumeni }\end{array}$ & $\begin{array}{c}\text { Percenlage } \\
\text { of Total }\end{array}$ & $\begin{array}{l}\text { Govemunent's } \\
\text { Residual Share }\end{array}$ & Type of Salc & Thate of Transfer & Sole Pince & \\
\hline \multicolumn{11}{|l|}{ I. $1991-98$} \\
\hline 1 SOBARA & Brexing & ... & & & & & Mexger /acquisition & 1992 & Merger /acquisitiun & \\
\hline 2 BRAKINA & Frewing & 9.47 & $2,530,020,000$ & $238,580,886$ & 0.21 & 0.00 & Sole of shares & $21-\mathrm{May}-92$ & $262,487,500$ & \\
\hline $3 \mathrm{SBMC}$ & Tanuing & 48.99 & $699,000,000$ & $342,440,190$ & 0.31 & 0.00 & Sale of shares & $1-4+10-92$ & $37,323,456$ & \\
\hline $4 \mathrm{SBCP}$ & Jeallurer and skins & 50.00 & 1,000,000,, 000 & $500,000,5000$ & 0.45 & 0.00 & Sale of shares & $30-54 n-92$ & $10,287,300$ & \\
\hline 5 SIFA & Motoreycles & 32.00 & $822,478,800$ & $263,193,216$ & 0.24 & 20,00 & Sole of shares & 9-Mar-93 & $71,500,000$ & \\
\hline 6 SOBCA. & Automobile louns & 100.00 & $500,000,000$ & $500,000,000$ & 0.45 & 18.55 & Capital inarease & 29-Mar-93 & Capital increase & \\
\hline 7 SONAR & Jisturatice & 52.08 & $480,000,000$ & $249,984,000$ & 0.22 & 25.00 & Sale of sthares & $9-$ Sep-93 & $360,875,000$ & \\
\hline 8 ZAMA-PUDULCTE & Adunrtising & 100.00 & $133,400,000$ & $133,400,000$ & 0.12 & 25.00 & Sale of sliares & $30-\operatorname{sep}-93$ & $102,454,000$ & \\
\hline 9 FASO-PLAST & Plastics & 34.60 & $681,490,000$ & $235,764,400$ & 0.21 & 7.00 & Sale of stares & 2-Nav-93 & $301,720,000$ & \\
\hline $10 \mathrm{OMB}$ & Flour minlling & 68.77 & $865,140,600$ & $594,956,778$ & 0.53 & 24.60 & Salp of shares & 26-Nov- 93 & $681,750,900$ & \\
\hline 11 CTMAT & Cement & 73.32 & $2,103,300,0100$ & $1,542,139,560$ & 1.39 & 22.80 & Sale of suares & 28-Dec-93 & $1,299,120,009$ & \\
\hline 12 SON/PILAKM & Tharmaceutical producls & 52.00 & $400,000,000$ & $208,000,000$ & 0.19 & 8.42 & Sale of shares & $10-A 1 g-94$ & $215,650,000$ & \\
\hline 13 SCFB & Reail tránspyort & $\ldots$ & $3,375,000,000$ & & $\ldots$ & & Operating concessinu & 12-Dea-94 & Opcrating concession & \\
\hline 14 PLEX FASO & Fruits & 95.00 & $317,8.10,000$ & $301,938,500$ & 0.27 & 25.23 & Sale of shares & 25-Mar-95 & $160,000,000$ & \\
\hline 15 SISB-CTIEC & Oils / soaps & 43.00 & $3,445,000,000$ & $1,48 \times, 350,000$ & 1.33 & 0.00 & Installment purchise & 1-Ju12-95 & Vuslalluent purcbase & \\
\hline 16 BISRKNA \& SHELIL & Elydrnearbon & 51.00 & $253,980,010$ & $129,529,800$ & 0.12 & 25.00 & Salc of shares & $30-\int^{3} w-95$ & $825,500,000$ & \\
\hline $17 \mathrm{CSPPA}$ & Local praducts & 100.00 & $25,000,000$ & $25,000,000$ & 0.02 & 0.00 & Liquidation & 1996 & $\ldots$ & \\
\hline 18 FASO YAAR & Generial cumbuerce & 71.54 & $2,209,000,00 \mathrm{n}$ & $1,580,318,600$ & 1.42 & 0.00 & Liquidation & 1996 & $\ldots$ & \\
\hline 19 RNTC-X9 & Urban transpont & 100.00 & $1,100,00 n, 000$ & $1,100,000,000$ & 0.99 & 25.00 & Operiting concession & 30.-3un-96 & Concession & \\
\hline 20 FASO-TOIRS & Jassenger transport & 38.00 & $\ldots$ & $\ldots$ & $\ldots$ & 0.00 & Sale of shares fur syonolic CFAF i & 23-Jul-96 & 1 & \\
\hline 21 SNAC & Slloes & 100,00 & $200,000,000$ & $200,001,000$ & 0.18 & 0.00 & Liquidatarts & 1997 & $\ldots$ & \\
\hline 22 SOFIVAR & Aggibusiness & 76.677 & $300,000,0000$ & $230,010,(4)$ & 0.21 & 0.00 & Liquidftion & 1998 & $\ldots$ & \\
\hline 23 SOBEMA & Enaruet & 50.00 & $2001,000,000$ & $100,000,000$ & 0.09 & 0.00 & Liquidation & 1998 & $\ldots$ & \\
\hline 24 ONAVET & Veterinary producls & 100.00 & $772,740,119)$ & $772,740,110$ & 0.69 & 0.00 & Liguidation & 1998 & $\ldots$ & \\
\hline $25 \mathrm{cNA}$ & Agricultural equipment & 100.09 & $533,000,000$ & $533,000,000$ & 0.48 & 0.00 & Liquidation & 1998 & $\ldots$ & \\
\hline 26 SOSUCO & Retïned sugar & 82.36 & $6,031,050,900$ & $4,967,172,780$ & 4.46 & 15.00 & Sale of sharea & 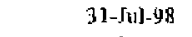 & $4,402,0001,00010$ & 1 \\
\hline 27 SOPAI. & Distilling & 93.93 & $582,920,000$ & $547,536,756$ & 0.49 & 7.86 & Sale of shares & $31-341-98$ & $753,0001,000$ & 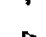 \\
\hline 28 EEED-TOT & Meal & 100.00 & $\ldots$ & $\ldots$ & $\ldots$ & $\ldots$ & 'Irmisfated lo MESSRS & $\ldots$ & $\ldots$ & 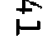 \\
\hline 29 НRЛЛСЕА & Fruils and vegetables & 100.00 & $\ldots$ & $\ldots$ & $\ldots$ & $\ldots$ & Trawsterted to MES.SRS & $\ldots$ & $\ldots$ & \\
\hline 30 MACEHOU & Frits and wejelables & $\ldots 1$ & $\ldots$ & $\ldots$ & $\ldots$ & $\ldots$ & Retunied to awher & $\ldots$ & $\ldots$ & 1 \\
\hline Tolal & & & & $16,777,055,486$ & 15.07 & & & & $9,483,667,857$ & \\
\hline \multicolumn{11}{|l|}{ II. 1999} \\
\hline 31 \$NTB & Trarsit & 46.80 & $390,0 \% 1,000$ & $179,490,000$ & 0.16 & 12.00 & Salle of shires & Mar- 99 & $398,970,600$ & \\
\hline 32 NNB & Printiag & 190.00 & $440,000,000$. & $440,6000,000$ & 0.40 & 18.90 & Sale of slares & Apr-99 & $325,000,000$ & \\
\hline 33 SONACOR & Rice ginuing & 9680 & $600,000,000$ & $544,800,1,00$ & 0.49 & 0.00 & I.jquidation & Jum-99: & $\ldots$ & \\
\hline 34 COMiKI & Mining & 100.00 & $\ldots$ & $\ldots$ & $\ldots$ & 0.00 & Tiquidalion & J41-99 & $\ldots$ & \\
\hline 35 SONACAB & Thies & 58.82 & $365,500,000$ & $214,987,100$ & 0.19 & 0.00 & Liquidation & 1099 & $\ldots$ & \\
\hline Intal & & & & $1,379,187,100$ & 1.24 & & & & $723,970,100$ & \\
\hline \multicolumn{11}{|l|}{ III. 2040} \\
\hline 36 SAVANA & Fruil juices & 94.102 & $103,795,820$ & $97,588,830$ & 0.09 & 0.00 & Liquidation & Feb-00 & & \\
\hline 37 SLM & Renting & 99.92 & $817,800,0110$ & $817,145,760$ & 0.73 & 5.00 & Sale of shates & Jแ -000 & $3,084,019,200$ & \\
\hline 38 sOCOAB & Real eslate & 36.84 & $1,862,600,000$ & $678,813,840$ & 0.61 & 0.00 & Sale of shares & Dec-00 & $\ldots$ & \\
\hline 39 AIR BURKDNA & Aviation & 99.75 & $35,000,000$ & $34,912,500$ & 0.03 & 14.60 & Capital increase & Dec-0i) & ... & \\
\hline Total & & & & $1,628,460,930$ & 1.46 & & & & $1,089,019,200$ & - \\
\hline \multicolumn{11}{|c|}{ NV. Fineaprises currently unuder privatization } \\
\hline 40 FASO FANT & Texliles & 71.27 & $1,626,170,000$ & $1,158,971,359$ & 1.04 & 0.00 & L.ig̨uidauien & Mata- 01 & & \\
\hline 41 SHG & Holels & 100.000 & $2,154,510,000$ & $2,154,510,000$ & 1.94 & 0.00 & Sale af assels & Apr- 01 & $1,845,000,000,000$ & \\
\hline 42 SONACTB & Cinemintograplyy & 82.16 & $350,000,000$ & $287,560,000$ & 0.26 & $\ldots$ & & $\ldots$ & $\ldots$ & \\
\hline $43 \mathrm{CNEA}$ & Agricultural equipnutal & 100.00 & $1,500,000,000$ & $1,500,000,010$ & 1.35 & $\ldots$ & $\ldots$ & $\ldots$ & $\ldots$ & \\
\hline 44 ONATEA. & Telecoumunications & 100.00 & $12,000,000,000$ & $12,400,000,000$ & 10.78 & $\ldots$ & $\ldots$ & $\ldots$ & $12,000,000,000.00$ & U \\
\hline 45 AIRYORTS & Airports & 100.00 & $\ldots$ & & $\ldots$ & $\ldots$ & $\ldots$ & $\ldots$ & $\ldots$ & \\
\hline 46 SONABEI & Flectricity & 100.00 & $48,097,071,777$ & $48,097,071,777$ & 43.20 & $\ldots$ & $\ldots$ & $\ldots$ & & \\
\hline 47 SONABBIF & P'elraleurn products & 2001.00 & $3,000,600,000$ & $3,000,000,0 \mathrm{nan}$ & 2.69 & $\ldots$ & $\ldots$ & $\ldots$ & & \\
\hline Tolal & & & & $68,198,113,136$ & 61.26 & & & & $13,845,000,000.00$ & if \\
\hline Total $\left(\left(1+\mathbb{I} \div \mathbb{M}+\mathbf{N}^{\prime}\right)\right.$ & & & & $87,982,816,652$ & 79.03 & & & & & \\
\hline
\end{tabular}

CInternational Monetary Fund. Not for Redistribution 
Table 10. Burkina Faso: Privatization Program (concluded)

(Th billinins of CPA frasus, unless olterwise specinied)

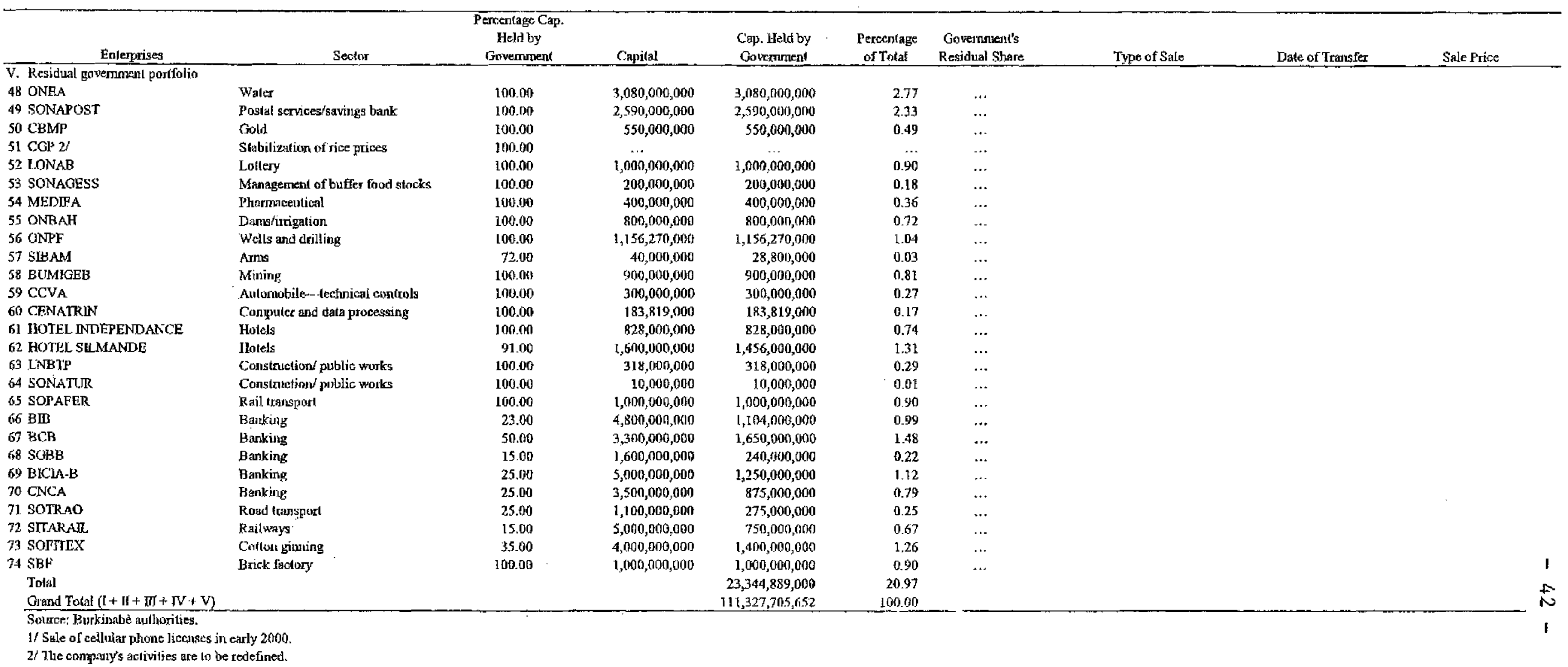


Table 11. Burkina Faso: Compliance with Regional Integration Under the WAEMU, 1997-2005 (In percent)

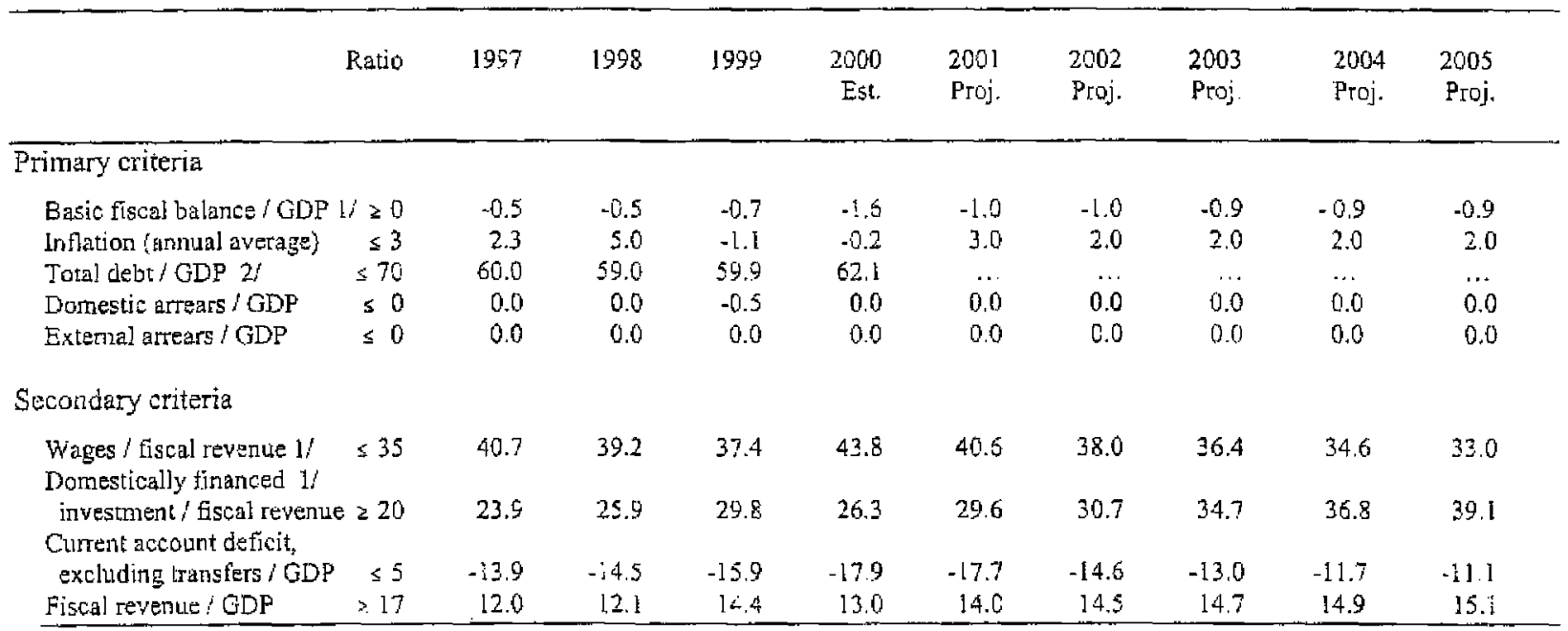

U/ Excluding lise of $\mathrm{HLC}$ thitiative resourees.

2) Extemal debt only. Based ou HIPC Initiative completion point and second tecision point document (EBS/00/113, 6/19/00). 
Table 12. Burkina Faso: Income anc Socjal Indicators

\begin{tabular}{|c|c|c|c|c|c|c|c|c|c|c|}
\hline \multirow[t]{2}{*}{ Gien } & \multirow[t]{2}{*}{ Ülit of Mensuremont } & \multicolumn{4}{|c|}{ Latest Single Year } & \multirow[b]{2}{*}{1996} & \multirow[b]{2}{*}{1997} & \multirow[b]{2}{*}{1998} & \multirow[b]{2}{*}{1999} & \multirow[b]{2}{*}{2000} \\
\hline & & 1975-79 & $1980-85$ & .993 & $990-95$ & & & & & \\
\hline Population & Thousands & $6,20 ?$ & 7,881 & $\ldots$ & 10,377 & 10,688 & 11,009 & 11,339 & 11,679 & 11,400 \\
\hline Population growth rate & Arhual average in percent & 2.1 & 26 & $\ldots$ & 2.9 & 3.0 & 3.0 & 3.0 & 2.8 & 2,8 \\
\hline Total fertility rate & Bitths per wonser: & 7.0 & 7.5 & 6.9 & 6.9 & 6.9 & $\ldots$ & $\ldots$ & 6.8 & $\ldots$ \\
\hline Urtan & & $\ldots$ & $\ldots$ & $\ldots$ & $\ldots$ & $\ldots$ & $\ldots$ & $\ldots$ & 4.1 & $\ldots$ \\
\hline Ru:ai & & $\ldots$ & $\ldots$ & $\cdots$ & $\cdots$ & $\ldots$ & $\ldots$ & $\ldots$ & 7.3 & $\cdots$ \\
\hline \multicolumn{11}{|l|}{ Powerty and cquity } \\
\hline Nationai poverty line & CFA tiancs & $\ldots$ & $\ldots$ & $\ldots$ & $4:, 099$ & $\ldots$ & $\cdots$ & 72.690 & $\ldots$ & $\ldots$ \\
\hline National head coust index & Parcent of population & $\ldots$ & $\ldots$ & $\ldots$ & 44.5 & $\ldots$ & $\ldots$ & 45.3 & $\ldots$ & $\ldots$ \\
\hline Utban & & $\cdots$ & $\cdots$ & $\cdots$ & 10.4 & $\cdots$ & $\ldots$ & 15.9 & $\cdots$ & $\ldots$ \\
\hline Ritral & & $\ldots$ & $\ldots$ & $\ldots$ & $5 ! .1$ & $\ldots$ & $\ldots$ & 50.7 & $\ldots$ & $\ldots$ \\
\hline GDP per capita & W.S. dollars & 150 & 180 & $\ldots$ & 234 & 237 & 217 & 229 & 208 & 206 \\
\hline \multicolumn{11}{|l|}{ Share of incone or consumption } \\
\hline Lowest quintile & Percent of inconte & $\ldots$ & $\ldots$ & $\ldots$ & $S$ & $\ldots$ & $\cdots$ & $\ldots$ & $\cdots$ & $\cdots$ \\
\hline Higisest quantile & Percont income & $\ldots$ & $\cdots$ & $\ldots$ & 56 & $\cdots$ & $\ldots$ & $\ldots$ & 63 & $\cdots$ \\
\hline Gini coefficient & & $\ldots$ & $\ldots$ & $\ldots$ & 0.63 & $\ldots$ & $\cdots$ & $\cdots$ & $\therefore$ & $\ldots$ \\
\hline \multicolumn{11}{|l|}{ Social fndicators } \\
\hline \multicolumn{11}{|l|}{ Gross primary school enrollment rate } \\
\hline Tocal & Poreent of school-age group & 16,0 & 29.0 & & 38.0 & 38.4 & 39.5 & 40.5 & 41.3 & 43.3 \\
\hline Male & Percent of school-age group & 21.0 & 36.0 & & 47.0 & 46.3 & 47.3 & 48.0 & 47.7 & $\ldots$ \\
\hline Fenale & Fecent of sciool-age group & 12,0 & 21.0 & & 30.0 & 27.8 & 32.2 & 33.6 & 34.6 & 35.9 \\
\hline \multicolumn{11}{|l|}{ Access to safe water } \\
\hline Total & Pcrcent of population & 25.0 & 35.0 & 65.0 & 650 & 78.0 & $\ldots$ & $\ldots$ & $\ldots$ & 78.0 \\
\hline Lirban & Percent of population & $\ldots$ & $\ldots$ & 93.4 & 93.4 & $\cdots$ & $\cdots$ & $\ldots$ & $\ldots$ & $\therefore$ \\
\hline Rutal & Percent of populztion & $\ldots$ & $\cdots$ & 58.1 & 58.1 & $\cdots$ & $\ldots$ & $\cdots$ & $\ldots$ & $\ldots$ \\
\hline Acess to adeçunte saritarion & Pencent of population. & $\ldots$ & $\ldots$ & $\ldots$ & $\ldots$ & $\ldots$ & $\cdots$ & $\ldots$ & $\ldots$ & $\ldots$ \\
\hline Total & & $\ldots$ & $\cdots$ & 18.1 & 18.1 & $\cdots$ & $\cdots$ & 180 & $\therefore$ & $\ldots$ \\
\hline Urbar & & $\ldots$ & $\ldots$ & 55,3 & 55.3 & $\cdots$ & $\cdots$ & $\ldots$ & $\cdots$ & $\ldots$ \\
\hline Rwall & & $\ldots$ & $\ldots$ & 9.1 & 9.1 & $\cdots$ & $\ldots$ & $\ldots$ & $m$ & $\cdots$ \\
\hline Child (unde: 5 ) malnutrition rale & Porcent of age group & & & & & & & & & \\
\hline Heigiot fo: age $1 /$ & & $\ldots$ & 48.5 & 29.4 & 29.4 & $\ldots$ & $\cdots$ & $\cdots$ & $\ldots$ & $\cdots$ \\
\hline Weiglit for age (cmacjation) & & $\ldots$ & $\ldots$ & 13.3 & 13.3 & $\cdots$ & $\ldots$ & $\ldots$ & $\ldots$ & $\ldots$ \\
\hline Life expectancy ar birth & Years & 41.1 & 44.9 & 52.0 & 52.0 & 52.2 & 51.2 & 52.4 & $\ldots$ & 54.0 \\
\hline [afant inortality rate & Per 1,000 live sisths & 137.0 & 117.0 & 93.7 & 93.7 & 98.0 & $\ldots$ & 105.03 & 104.0 & 1040 \\
\hline Under-5 mortality rute & Per 1,000 live birtizs & $\ldots$ & $\ldots$ & 214.0 & 214.0 & $\ldots$ & $\ldots$ & 219.0 & $\ldots$ & $\ldots$ \\
\hline Adul tnortalisy & Per 1,000 population & 24.5 & 19.9 & $\ldots$ & 18.1 & $\ldots$ & $\ldots$ & 16.4 & $\ldots$ & $\ldots$ \\
\hline Birth assisted & Fercent & $\ldots$ & $\ldots$ & 41.5 & 32.9 & 26.9 & $\therefore$ & 27.0 & 34,0 & 32.1 \\
\hline Materna! moltalicy late & PEl ! 00,000 live births & $\ldots$ & 600.0 & .566 .0 & 939.0 & 930.0 & $\cdots$ & 930.0 & $\ldots$ & $\ldots$ \\
\hline HIV prevalence & Fercelut of population & $\ldots$ & $\ldots$ & $\ldots$ & $\ldots$ & $\cdots$ & $\ldots$ & 7,0 & $\therefore$ & 7.2 \\
\hline \multicolumn{11}{|l|}{ Medical personnel availability } \\
\hline Doctor & People per doctor & $\ldots$ & $\ldots$ & $m$ & 28,673 & 29,815 & 29,589 & 23,308 & $\ldots$ & $\ldots$ \\
\hline Midwife & People per riddwife & $\cdots$ & $\ldots$ & $\cdots$ & 23,316 & 29,897 & $25,56 \pm$ & 25,050 & $\ldots$ & ... \\
\hline
\end{tabular}

Sounces: World Bank, Socich Mndicators of Dovelopment, 1996; and World Bank and LWF staff estimates.

1/ Percent of children in age group lut winch the weight-to-age ratio s less than 2 standard devintions below the reference sample mean. 
Ouagadougou, November 2, 2001

Mr. Horst Köhler

Managing Director

International Monetary Fund

Washington, D.C. 20431

Dear Mr. Köhler:

1. On behalf of the government of Burkina Faso, and in the context of the fourth review of the program supported by an arrangement under the Poverty Reduction and Growth Facility (PRGF) approved by the Executive Board of the International Monetary Fund on September 10, 1999, I am pleased to forward you the memorandum on economic and financial policies for 2001-02 (July -June). The memorandum describes progress made in implementing the program thus far in 2001, updated objectives for end-2001 and for 2002, and the policies to be implemented to achieve these targets.

2. The 2001 program has been implemented in the context of lingering growth in the first half of the year, following the downturn of 2000 . Nonetheless, expenditure cuts made it possible to offset a shortfall in tax revenue, and all the end-June 2001 quantitative and structural performance criteria, benchmarks, and indicators were met, except for the indicator on the level of tax revenue.

3. Owing to the rigorous implementation of the program, the end-September 2001 quantitative benchmarks and structural performance criterion have also been observed. In particular, the National Savings Bank's deposits at the treasury were securitized on September 21, 2001 (a structural performance criterion by end-September 2001). For the year as a whole, the government is determined to achieve the programmed overall deficit target by offsetting the projected fiscal revenue shortfall (estimated at 0.5 percent of GDP) and an upward revision of the wage bill ( 0.4 percent of GDP) through expenditure cuts equivalent to 1.1 percent of GDP, while safeguarding priority poverty reduction expenditure. To strengthen tax recejpts, the government has also decided to increase excise taxes on gasoline and to introduce an excise tax on diesel oil.

4. The outlook for 2002 , during which important legislative elections will be held, remains favorable. The draft 2002 budget is in line with the program objectives. In particular, the overall fiscal deficit (commitment basis) will be kept to about 4 percent of GDP. The government remains resolved to carry out all the reforms and measures contained in the program. It considers that the policies and measures described in the memorandum are adequate to achieve its program objectives, but it is ready to take further measures that may prove necessary for this purpose. During the period of the third 
annual PRGF arrangement, the government will consult with the Managing Director on the adoption of any measure deemed appropriate, at its own initiative or whenever the Managing Director requests such a consultation. In addition, after the period covered by the third arrangement and while Burkina Faso has financial obligations to the Fund arising from loans granted under this arrangement, the government will consult with the Fund periodically, at the government's initiative or whenever the Managing Dircetor requests a consultation on Burkina Faso's economic and financial policies.

5. As described in the memorandum, debt-service relief obtained since reaching the completion point under the original Heavily Indebted Poor Countries (HIPC) Initiative and the interim assistance obtained under the enhanced HIPC Initiative have been allocated to the priority poverty reduction programs contained in the poverty reduction stratcgy paper (PRSP). These resources, as well as stepped-up action on the part of the government with respect to poverty reduction, made it possible to mect all the policy reform conditions for the enhanced HIPC Initiative completion point by March 2001. A first PRSP progress report was finalized in October 2001 after broad consultations with civil society and the country's development partners.

6. The government solicits the continued support of the International Monetary Fund to help it meet its program objectives, including through the completion of the fourth review under the PRGF arrangement. Also, the Fund will, together with the government of Burkina Faso, complete a fifth review of the PRGF-supported program by June 30,2002 , so as to monitor progress made in its implementation. As in the past, the government consents to publication of the International Monetary Fund staff rcport.

Sincerely yours,

$/ \mathrm{S} /$

Jean-Baptiste Compaoré

Deputy Minister to the Prime Minister

in charge of Finance and Budget

Ouagadougou, Burkina Faso

Attachments: Memorandum on economic and financial policies for 2001-02 and technical memorandum of understanding 


\section{BURKINA FASO}

\section{Memorandum on Economic and Financial Policies for 2001-02}

November 2, 2001

\section{PRogray ImPlementation DURing The First SiX Months of 2001}

1. Despite some slowness in the economic recovery during the first half of 2001 as the result of the poor cereals harvest at end-2000, Burkina Faso resolutely pursued the implementation of its program for 2000/01, supported by the Poverty Reduction and Growth Facility (PRGF), as described in the memorandum on economic and financial policies of June 6,2001 . The government also stepped up its poverty reduction program, as outlined in the poverty reduction strategy paper (PRSP). It allocated to priority programs increased budget resources, debt-service relief obtained after Burkina Faso had reached the completion point under the original Heavily Indebted Poor Countries (HIPC) Initiative, and interim assistance received under the enhanced HIPC Initiative. As a result, Burkina Faso had alrcady met all the policy reform conditions for the completion point under the enhanced HIPC Initiative by March 2001 and strengthened the country's health and education coverage. These developments are described in the first progress report on the PRSP, finalized in October 2001 after broad consultations with civil society and development partners.

2. The weak growth of 2000 depressed fiscal revenue during the first half of 2001 . Faced with this shortfall and a low level of budgetary assistance in the early part of the ycar, the government appropriately slowed the rate of expenditure commitments. This enabled it to meet all quantitative performance criteria, benchmarks, and indicators at end-Junc 2001, with the exception of the tax revenue indicator. All the end-June and end-September 2001 structural performance criteria and benchmarks were also met. By end-June 2001, the interconnections between the civil service and payroll databases had been completed, and a centralized database to monitor social expenditure and outcomes had been set up. The National Savings Bank's deposits at the Treasury were securitized on September 21, 2001.

3. The subdued growth and consumption in the first half of 2001 adversely affected revenue. Tax revenue totaled CFAF 103.0 billion (12 percent of GDP), against a target of CFAF 128 billion for that period. Income and profit tax revenues were particularly affected, ending up approximately 30 percent below forecast. As a result of a freeze in commitments, current expenditure totaled CFAF 107 billion (12.5 percent of GDP), approximately CFAF 7 billion ( 0.4 percent of GDP) below the program target. This outcome also reflected smaller-than-expected subsidies on petrolcum products. The end-June indicator on expenditure on wages and salaries was met. Domestically financed capital expenditure was in line with projections. Overall, the basic and overall deficits (on a commitment basis, including grants) were larger than forecast and some cash-flow pressures led to a substantial incrcase in deposits with the treasury. In light of the relatively low level of external support, 
the government financed the deficit through a CFAF 9.4 billion issue of treasury bills in February, while observing the performance criterion on net bank credit to the government.

4. The money supply and credit to the economy were stable during the first half of 2001. Bank portfolio soundness deteriorated slightly during the first half of the year, as some banks had not yet provisioned new doubtful claims. The key prudential ratios of the West African Monctary Union (WAMU) were nonetheless observed. One of the main local banks, which had experienced management problems, replenished its capital as recommended by the WAMU Banking Commission. Microfinance institutions (the network of credit unions and other local networks) continued to develop, in particular through a stronger concentration in cities, as illustrated by a 38 percent rate of growth in deposits in 2000 . By contrast, credit declined by 26 percent, resulting in some excess liquidity, which was for the most part deposited with local commercial banks.

\section{ObJeCtives ANd POlicies for End-2001}

\section{Real GDP growth is estimated to be slightly above 6 percent in 2001,} as projected in the program. Stimulated by an increase in producer prices of approximately 18 percent (including the bonus payment), along with propitious rainfalls, cottonseed production is expected to grow by 45 percent to 400,000 tons. This abundant harvest should increase the revenue of cotton growers (about 18 percent of the population) by approximately 73 percent, contributing significantly to poverty reduction in rural areas. Moreover, as a result of the anticipated good cereals harvest, the primary sector can be expected to grow by 8.6 percent after a decline of about 4 percent in 2000 . By contrast, reflecting a slow recovery in economic activity during the first six months, the secondary and tertiary sectors are expected to grow only moderately. Because of cereals shortages, consumer prices had risen by 4.9 percent on a year-on-year basis by end-September 2001 . Howcver, with the expected decline in cereals prices in the last quarter of the year, the average increase in consumer prices should be about 3 percent in 2001, as originally targeted. The GDP deflator is projected to increase by 3.7 percent. Despite an increase in public investment financed by external resources, combincd with a slight increase in private investment, the savings-investment balance should improve slightly to 14 percent of GDP, compared with 14.3 percent in 2000 .

6. The external current account deficit, excluding grants, is projected to decline to 17.7 percent of GDP in 2001 (14 percent of GDP, including grants) from 17.9 percent of GDP in 2000. The increase in export rcccipts, owing to higher prices and larger volumes of cotton exports, is expected to be offset by the substantially higher-than-initially projected Icvel of imports on account of higher petroleum prices. In addition, the increase in official transfers would be offset by a drop in workers' remittances. The overall deficit is expected to be only half the level in 2000 on account of larger external disbursements, thereby leading to an accumulation of gross external reserves of CFAF 7 billion.

7. On the fiscal policy side, the decline in revenue projected for the rest of the year will be balanced by a decrease in nonessential expenditure to achieve the programmed 
deficit. To secure a tax revenue level of 14 percent of GDP (which would be 0.5 percent of GDP below target but up by 1 percent of GDP from the level achieved in 2000), the government has, inter alia, increased the tax on petroleum products (TPP) applicable to premium and regular gasoline and introduced a TPP on diesel oil in October 2001. The direct impact of the increase in petroleum taxation on poverty will be limited, as it primarily affects more affluent households, and as socially sensitive products (kerosene and butane gas) will remain exempted. Nonetheless, the government will regularly revicw the indirect effect of this measure on poverty, including through its impact on transportation costs. Moreover, the government is undertaking a full tax census and will intensify its efforts to expand the tax base-actions that are expected to have positive effects on revenue before the end of the year.

8. On the expenditure side, the freeze in commitments, which generated savings of CFAF 7 billion during the first half of the year, will be continued, resulting in savings totaling CFAF 12.5 billion ( 0.7 percent of GDP), compared with program projections; at the same time, the priority sectors of health, education, and rural development will be protected. While the wage bill for the full year has been revised upward by 0.4 percent of GDP to accommodate new hiring in the social arcas (in particular education and health) and some retroactive wage and indemnities adjustments linked to the new salary grid, petroleum subsidies have been revised downward by 0.3 percent of GDP bccausc of the decline in international prices; meanwhile current expenditure will be cut on a cumulative basis by 0.8 percent of GDP through contingency measures. Special attention will be paid to refunds of value-added tax (VAT) credits owed to the cotton company (SOFITEX) for prior and current fiscal years, which amount to at lcast CFAF 6.7 billion. Capital expenditure, devoted essentially to the priority sectors, will be in line with projections. In addition, projections indicate that, on a commitment basis, the share of budget expenditure (excluding external financing and HIPC Initiative related resources) allocated to the health and education sectors will amount to 13.4 percent and 16.2 percent, respectively, as targeted in the program (compared with targets of 12.4 percent and 15 percent in 2000) (Appendix I, Table 2). In addition, to offset the shortfalls in the mobilization of resources freed as a result of the HIPC Initiative and to ensure that the poverty reduction program of the PRSP is implemented in its entirety, CFAF 3.4 billion in budgetary grants will be used to finance the HIPC Initiative 2001 expenditure program, which will therefore amount to the CFAF 25 billion initially provided in the PRSP.

9. Because the lower revenue was offset by expenditure cuts, the overall deficit (on a commitment basis, including grants) will be limited to the programmed level of about 5 percent of GDP. Excluding expenditure financed by the HIPC Initiative, the basic deficit ${ }^{1}$ of 1.4 percent of GDP will be slightly lower than in 2000. A higher-than-expected mobilization of external assistance will allow for some reduction in domestic debt at the level

\footnotetext{
${ }^{1}$ Defined as total revenue, excluding grants, less total expenditure, excluding externally financed investment expenditure.
} 
of the treasury. Also, the decline in domestic banking indebtedness has been revised to CFAF 5.2 billion, slightly larger than the projected level, to take into account the first scheduled repayments under the securitized postal debt.

\section{The government has pursued its objective of improving public expenditure}

management. In 2001, the government has promptly paid its water, electricity, and telephone bills. It has also finalized the settlement of all balances still owed to the related suppliers by securilizing the last remaining balances owed to the electricity company SONABEL, in September 2001. In addition, to improve cash-flow management, the treasury is continuing its efforts to reduce the number of deposit accounts in its books, following the sharp increase in the number of accounts in recent years, particularly by closing out private sector accounts. So far, 230 accounts to be closed before end-2001 were identified, and 14 accounts of private depositors have already been closed. In addition, the structural performance criterion at end-September on the securitization of CNE (Postal Savings Bank) deposits with the treasury was met on September 21,2001, thus restoring the liquidity of the $\mathrm{CNE}$ and allowing for reentry of the $\mathrm{CCP} / \mathrm{CNE}$ into the clearinghouse.

11. The money supply is projected to expand by 6.4 percent in 2001. Domestic credit should increase by approximately 8 percent, reflecting a very slight increase in net credit to the government and a rise in credit to the economy of approximately 9 percent. Following the delays observed during the first half of the year, crop credits should be repaid on schedule. Moreover, the government will comply with the decision to be taken by the WAMU Council of Ministers in December 2001 concerning the repayment of statutory advances from the central bank.

12. In the area of structural reform, substantial progress was made in improving public expenditure management with the assistance of the World Bank. The Budget Management Improvement Plan (PRGB), which will serve as a frame of reference for budget management reform, was adopted by Burkina Faso's Council of Ministers in September 2001. This would include more effective expenditure programming, enhanced discipline and transparency, and the strengthening of expenditure control. In this regard, the govcrnment plans to accelerate the establishment and beginning of operation of the four courts that will be replacing the Supreme Court. ${ }^{2}$ In light of the importance of the Audit Court for monitoring budget management, the government will ensure that the required administrative and institutional steps are taken so that this court is fully operational by endDecember 2001 (a structural benchmark under the program). Efforts will also be made to ensure that reliable treasury balances and operating accounts, which are essential for the Audit Court to examine the government's financial situation, are available. Preparation of the Budget Review Law (loi de règlement) for fiscal-year 1999 is well advanced, and the act for fiscal-year 2000 should be finalized more quickly than in the past as a result of the interconnection of the various financial computer software programs involved.

${ }^{2}$ Council of State, Constitutional Court, Supreme Audit Court, and Court of Cassation. 
The government also intends to finalize the Country Financial Accountability Assessment by end-2001. In addition, the action plan concerning the capacity of budget management to monitor HIPC Initiative related expenditure and other outlays earmarked for poverty reduction, which was developed with technical assistance from the $\mathrm{IMF}$, is being implemented.

13. Progress has been made with the National Good Governance, particularly through the continued consultations among the government, private sector, and civil society. The reform program of the judiciary was finalized and discussed with development partners in June 2001. To solve the problems related to the awarding of public contracts identified during surveys by the National Institute of Statistics and Demographics (INSD), the reform of public contracting procedures will be finalized by the end of the ycar. Furthermore, the anticorruption unit cnvisaged in the PRSP will become operational by end-December 2001 (a structural performance criterion under the program). The unit will be independent of the government and will have the jurisdiction to investigate and review cases and to refer them to the competent judicial authorities.

\section{OBJECTIVES AND POLICIES FOR 2002}

\section{2002 will be marked by a difficult international environment, in particular by} falling cotton export prices; at the same time, important legislative elections will be held. The farmers' keen interest in increasing land areas planted with cotton and related cereals, particularly in the new zones open to these crops, is something that the government aims to preserve as a key factor in the fight against poverty. In close collaboration with the cotton producers' associations, the government intends to continue to offer farmers a profitable price while ensuring the financial equilibrium of the sector. Accordingly, the government remains confident that cottonseed production could increase by approximately 5 percent in 2002, and the primary sector by about 4 percent. As a result of the positive spillovers of the abundant cotton and cereals harvests expected for end-2001, the secondary and tertiary sectors are expected to increase by 7.5 percent and 6.5 percent, respectively. All in all, GDP growth is projected at 5.8 percent in 2002 . With the abundant availability of foodstuffs, the inflation rate is projected at an annual average of 2 percent. For the period 2003-05, real GDP growth should increase on average by approximately $51 / 2$ percent per annum, and include an uptick in private sector investment.

15. In light of the uncertainties linked in particular with low international cotton prices, the government reviewed its downside risk scenario for 2002 and the medium term (i.e., lower cotton and cereals production and a continued low level of workers' remittances). Based on these assumptions, real GDP growth should reach only 4.9 percent in 2002 and 4.6 percent, on average, in 2003-05. The savings-investment balance will detcriorate. Beginning in 2003, the lower level of cotton exports and workers' remittances should cause a widening of the external current account deficit. The overall fiscal balance will show the emergencc of financing gaps; however, these will be sustainable and financeable through a mix of domestic adjustment and some higher level of financing. 
16. With regard to the balance of payments for 2002 , the substantial increase in the volume of cotton harvested in late 2001 but exported in 2002 should lead to a sharp recovery in exports. The expected decline in petroleum prices and in the exchange rate of the dollar against the euro should result in a modest decline in the level of imports. Hence, notwithstanding a further decline in workers' remittances, the current account deficit, excluding grants, is expected to improve by 14.6 percent of GDP (10.4 percent, including grants) as against 17.7 percent in 2001. The overall deficit is also projected to improve, leading to an accumulation in official reserves, projected at approximately CFAF 15 billion. In the medium term, the current account deficit is projected to continue to decline, mainly as a result of an expected increase in cotton exports in the baseline scenario.

17. The fiscal policy objective for 2002 and the medium term is a gradual reduction in the basic and overall deficits, with a view to limiting government borrowing. Consistent with this objective, the basic deficit (excluding HIPC initiative resources) will be kept at around 1 percent of GDP, and the overall deficit (on a commitment basis and including grants) at about 4 percent of GDP in 2002. Tax revenue is projected at 14.5 percent of GDP, an increase of 0.5 percentage point of GDP compared with 2001, reflecting the upturn in growth, as well as a number of new measures in the area of domestic taxation that the government intends to submit to parliament in the 2002 budget exercise. In particular, to offset the weaknesses observed in recent years, the government plans to assign the collection of the tourism development tax to the tax directorate (DGI). In addition, to adhere to the West African Economic and Monetary Union (WAEMU) regional norms, the thresholds for income taxes and the VAT will be revised downward. The necessary steps will be taken so that VAT credits would offset VAT liabilities on receipts (a benchmark for endDecember 2001 under the program). The government will also undertake a study to subject the hydrocarbon transport sector to the VAT. If the downward trend in petroleum product prices continues, the government will consider increasing the rates of the petroleum product tax during the year to protect revenue levels.

18. Current expenditure (excluding HIPC initiative resources) is projected at CFAF 223 billion in 2002, a slight decline as a percentage of GDP (to 12 percent of GDP, compared with 12.2 percent in 2001). There will be no gencral wage increase in 2002; the wage drift and some recruitment in the social sectors should account for about a 3 percent increase in the overall wage bill, and an allowance was added for the planned adjustment in indemnities. As part of the fight against poverty, expenditure on basic education and decentralization will be above the average increase in expenditure. By contrast, current outlays allocated to the presidency and defense will be held well below the average increase in expenditure, correcting the sharp increases recorded in recent years. The government will pursue its policy of promptly paying its water, electricity, and telephone bills, and will not incur any arrears in this area. A slight increase in capital expenditure is projected as a result of a special effort to mobilize domestic resources for investment, particularly in areas related to poverty reduction. In this connection, expenditure will encompass HIPC related resources totaling CFAF 25.2 billion (1.4 percent of GDP). All in all, a substantial planned mobilization of external assistance will cnable a further reduction in domestic indebtedness. In addition, efforts planned by key donors to improve the intra-annual distribution of external aid 
disbursements should make it possible to avoid the liquidity problems experienced by the treasury in the past.

19. In light of the importance of regional integration for a landlocked economy such as Burkina Faso's government will make every effort necessary to comply with the directives of the West African Economic and Monetary Union (WAEMU). Mindful that the country will be unable to meet all the convergence criteria by end-2002, the government will strive to comply within a reasonable time frame. In accordance with the WAEMU directives that are expected to be issued following consultations with the World Trade Organization, it will reduce the still substantial list of products subject to administratively set customs values, which was reviewed in May 2001. In addition, to supplement the substantial progress already made in this area, the government will continue to adapt its national legislation to comply with the five directives for harmonization of the government finance statistics and the accounting and legal framework. In particular, the computerized government accounting framework will be fully operational by end-2001. Moreover, progress is being made to improve the statistical base of the decentralized entities and autonomous agencies-a necessary step to widen before end-2002 the coverage of the summary tablc of financial operations (TOFE).

20. In keeping with the monetary policy objectives of the Central Bank of West African States (BCEAO) directed at consolidating the union's international reserves and maintaining a level of inflation in linc with that of the anchor currency, the money supply is projected to expand by approximately 8 percent in 2002, thereby keeping pace with nominal GDP growth. Credit to the government is projected to decline slightly and credit to the economy to increase by approximately 8.5 percent, consistent with projected trends in economic activity. With a favorable cotton harvest, it is expected that crop credits will be repaid on time and residual balances from earlier growing seasons cleared. The banking system will be strengthened further, particularly through increases in bank capital and reserves, and banks will endeavor to comply with the new capital adequacy ratio that will become effective on January 1, 2002. The government will continue to promote sound development of microfinance, including through a strengthening of the supervision capacity. To implement the WAEMU Council of Ministers' decision to eliminate statutory advances from the BCEAO and to permit full substitutability between bank financing and bills or bonds issued by the treasury on the national or regional financial market, the performance criterion on the change in net bank credit to the government will be rcplaced from 2002 onward with a performance criterion on net domestic financing (bank and nonbank). The indicative ceilings under this new performance criterion are set at CFAF 11.5 billion at end-March 2002, and -6.3 billion at end-June 2002 .

21. With support from the World Bank, the privatization program will be pursued in 2002. After the privatization of the railroad hotel company (SHG) and the national film company (SONACIB), scheduled for end-2001, the first wave of the privatization program for 2002 includes three companies: the national agricultural equipment center (CNEA), following its merger with APICOMA; the management of the airports; the telecommunications company (ONATEL); and, in the energy sector, the opening of the 
capital of the electricity company (SONABEL) and the petroleum distribution company (SONABHY) to private investors. When these operations have been completed, 47 enterprises, representing 79 percent of the government's original portfolio, will have been liquidated or sold. The remaining 21 enterprises will form part of the second wave of privatizations, which could begin already in 2002. In addition, the government will accelerate studies on the interconnection of the electricity grid with the grids of certain countries in the subregion, with a view to rapidly reducing the cost of electricity in Burkina Faso.

22. The reform of the cotton sector continues. The government is undertaking a study on the financing of cotton inputs, an activity from which SOFITEX intends to withdraw as of the 2002/03 season. The various industry participants will remain vigilant and take timely steps to restore equilibrium in the sector if such steps are required by developments in international cotton prices. These might include a call for increased donors' assistance to finance some subsidization of the producer price, so as to minimize the social impact of a decline in prices.

23. Following the adoption of the new merit-based promotion system, the civil service reform will continue. Special emphasis will be placed on decentralization and devolution policies, inchuding the transfer of human resources. With the continued assistance of the World Bank, the government will intensify its efforts to create an environment more conducive to development of the private sector, in particular through the establishment of the business resource center and the simplification of the administrative proccdures for setting up enterprises. The number of formalities has already been reduced from fifteen to eight, and the target of four formalities will be reached by end-2002. Finally, an action plan with a completion timetable will be adopted to enhance the competitiveness of enterprises, as indicated in the study on the macroeconomic implications for aggregate supply of the enterprise taxation policy.

24. The program will continue to be monitored quarterly on the basis of the quantitative performance criteria, benchmarks, and indicators found in Table 1 and in the technical memorandum of understanding, as well as on the basis of the structural performance criteria and benchmarks for end-December 2001 shown in Table 3. For 2002, the key benchmark/performance criterion is the ceiling on the cumulative change in net domestic credit. Others include zero ceilings on new nonconcessional external borrowing ${ }^{3}$ and on the accumulation of domestic and external payments arrears. The quantitative indicators include a cumulative floor on government revenue, and cumulative ceilings on expenditure on wages and salaries and current expenditure. Making the anticorruption unit operational is a performance criterion for end-December 2001. Amendment of existing legislation to deduct VAT credits henceforth from receipts and adoption of administrative and institutional measures to make the Supreme Audit Court opcrational are structural benchmarks for end-

\footnotetext{
${ }^{3}$ Excluding treasury bonds and bills issued in CFA francs on the national or WAEMU regional financial market.
} 
December 2001. Quantitative and structural performance criteria, benchmarks, and indicators for end-June 2002 with respect to the seventh disbursement will be established during the fifth program review, scheduled to be completed by June 30, 2002.

25. Statistical data. As part of the national strategy in the area of statistical data, the government is stepping up its efforts to improve the quality and regular production of the national accounts and other economic statistics. In this connection, the INSD's allocations in human and material resources will be significantly raised in the 2002 budget, following the INSD's conversion into an autonomous agency. A report on the General Data Dissemination System (GDDS) has been forwarded to the Council of Ministcrs for adoption. The national accounts for 1998 will be finalized by end-2001, after some delays. The effort to harmonize the industrial production index in the context of the WAEMU will be completed in 2002.

\section{Poverty Reduction and Social Sectors}

26. After broad consultation with civil society, the government presented the first progress report on the PRSP in October 2001. The report (i) takes stock of the progress made and problems encountered in implementing the plan of priority actions for each of the four pillars of the strategy; (ii) reports on the results of consultations undertaken with all parties involved in preparing the assessment and update of the PRSP; and (iii) outlines some possible approaches for remedial actions to be taken in light of the analyses provided in the report and the concerns expressed by the various partners during the consultation process.

27. This progress report was presentcd in conjunction with a scparate report, assessing the conditionalities for the completion point under the enhanced HIPC Initiative. The latter report shows that, despite lower-than-envisaged debt relief for Burkina Faso under the Initiative and a slower-than-anticipated mobilization of resources, all targets set as conditions for reaching the completion point have been achieved. In addition, the technical work to calculate debt sustainability has already been undertaken.

28. Steps taken to implement the PRSP and forthcoming stages are described in the progress report. Effective monitoring of the mobilization and use of HIPC initiative resources has been achieved through the treasury's special account for the use of these resources. The other monitoring procedures continue to be strengthened at the central and regional levels. In particular, the monitoring unit created in June 2001 to establish a centralized database on the evolution of all poverty-reducing expenditure and outcomes will be able-as soon as its software is operational, but certainly before end-2001- to collect and disseminate detailed, real-time data on the results achieved. Furthermore, the government will endeavor to eliminate certain bottlenecks observed in the commitment and settlement of available appropriations. In particular, HIPC initiative resources for 2001 will be committed in their entirety by the end of the year and disbursed by June 30,2002. Moreover, the decree allocating the disbursement of HIPC initiative resources in 2002 will be adopted at the latest by March 31, 2002. 
29. Budgetary decentralization, that is, giving the authority to manage funds through the delegation of appropriations to decentralized units of ministries (down to health districts in the area of health), has yielded compelling results. Expansion of this process is being studied. Now limited to the Ministries of Health, Basic Education, and Decentralization, devolution should also be extended to the Ministries of Agriculture, Animal Husbandry, Environment and Water Resources, and then gradually to other ministries. Devolution, which now only affects expenditure on goods and services, will also be extended to capital expenditure. 
(In bilkiniss of CFA francs; cumvlarive from beginning of year)

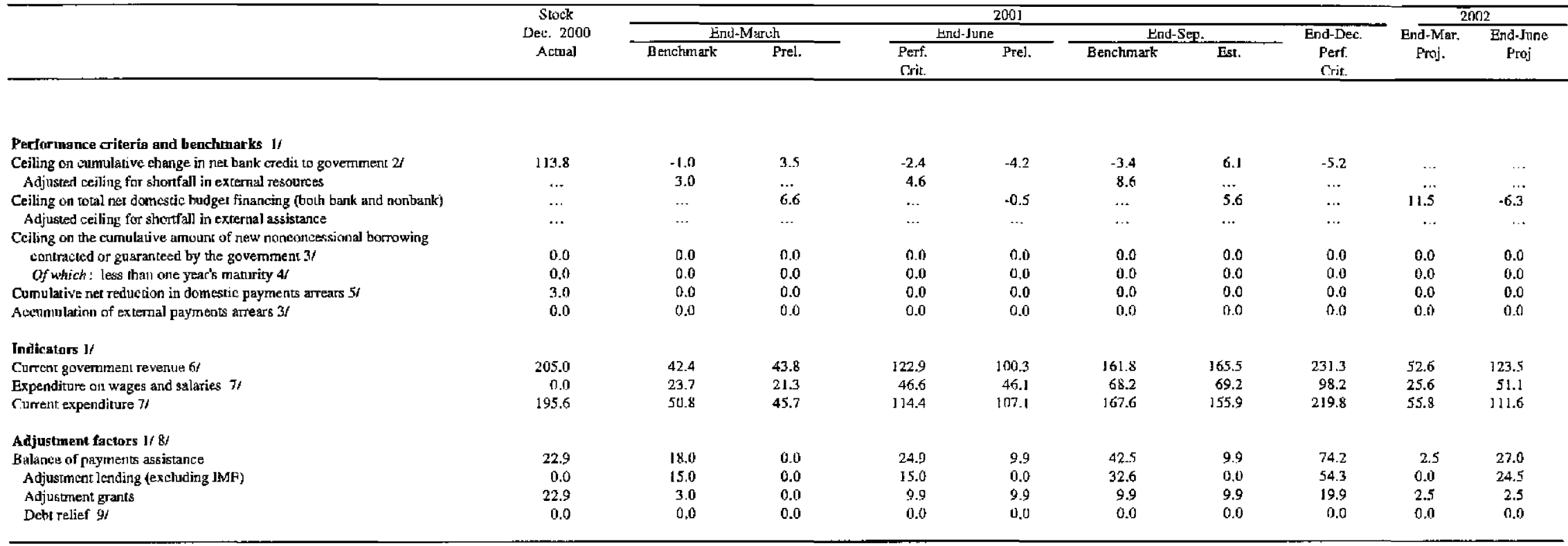

Sources: Hurkinabe authonities; and staff estimates and projections.

1/ As defined in the technical memorandum of understanding.

$2 /$ For end-Sepremher and end-December 2001, to be sdjusted for the amount of treasury bonds or bills issued for the repayment of the stock of $\mathrm{BCBu}$ O advances.

3i To be observed on a continuous basis. Excluding treasury notes and bonds issued in CFA francs on the regional WAEMU marke.

4/ Exchuiling unenal impom-felated credits and treasury notes and bonds issined in CFA fiancs on the rcgional WAEMUI market.

S/ For 2000, inchudes retroactive wage adjusiments that, in the stimmarry fiscal table, bave been included in wages and salaries.

fi Fxoluding revenue collected through treasiry check.

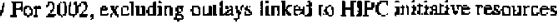

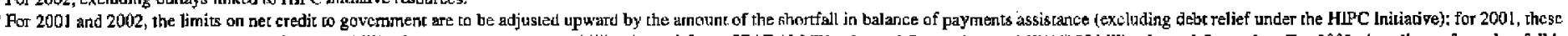

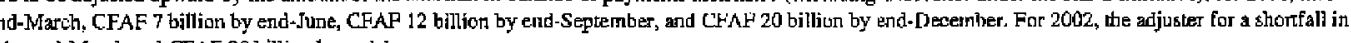
9/ Excluding HIPC Jnitiative delt retief. 
Table 2. Social Development Performance Indicators, 1996-2003

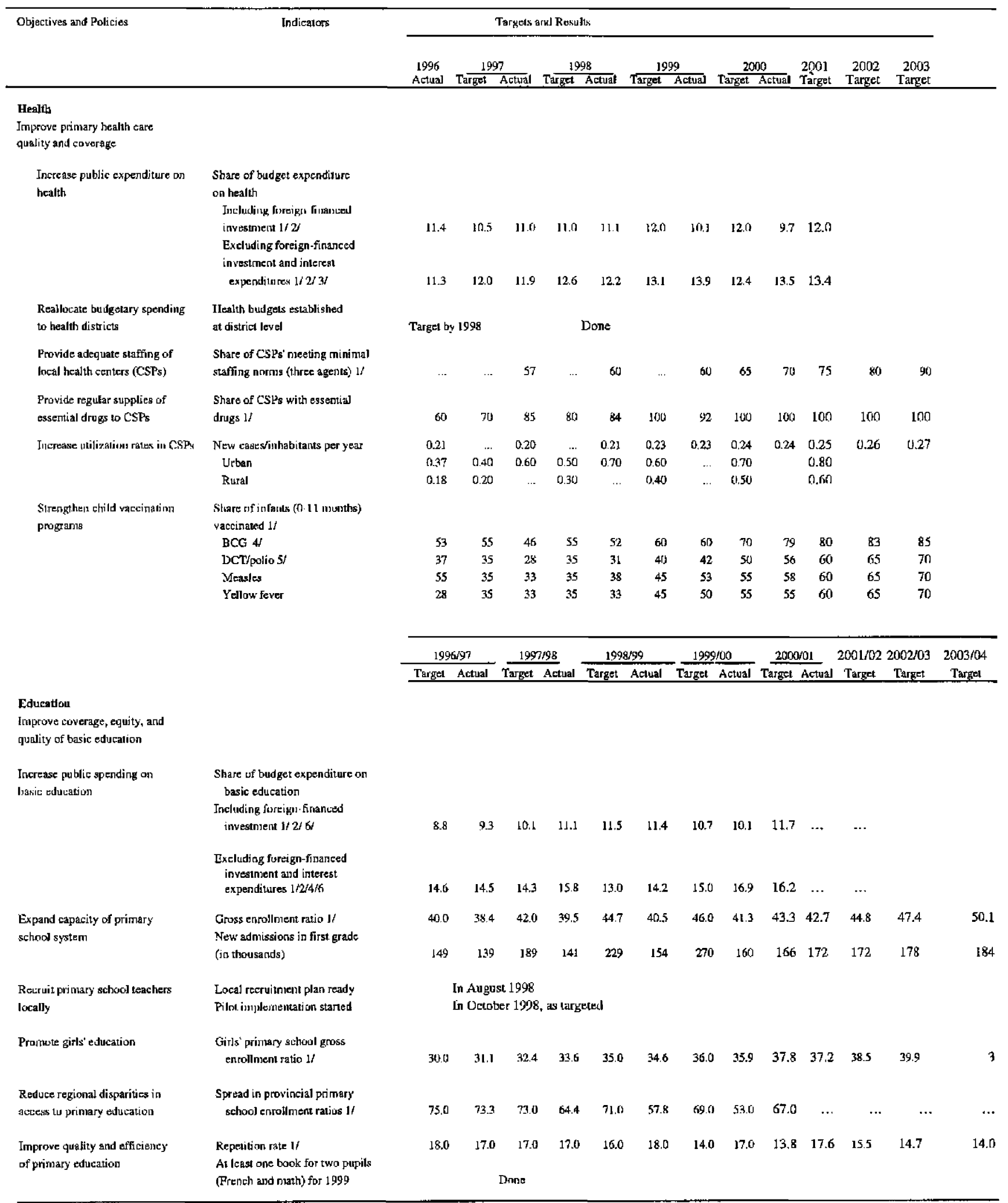

Source: Burkinabé nuthorities.

IS In percent.

2/ On a conrmitment basis, cxcluding external debt serwice

3/ Not part of idertified Initistive for Heavily Indebled Pors Cusuntries (HTPC Initiative) targets

4/ Tuberculusis.

5/ Diphtheria, chntera, and Iotactus/pulio

6) Budgetary dat: rofer to initial year of sclrool year 
Table 3. Burkina Faso: Structural Benchmarks and Performance

Criteria for the 2001-02 Program

\begin{abstract}
Measures
Reform of petroleum products taxation in compliance with

West African Economic and Monetary Union (WAEMU) norms.'

Adoption by the Council of Ministers of the letter of development policy of the energy sector, including the regulatory framework for the electricity sector and the plan for the privatization of the electricity company (SONABEL).

Introduction of automatic domestic price-setting mechanisms for petroleum products reflecting movements in international prices.'
\end{abstract}

Adoption of audited budget acts (Lois de règlement) from 1995 to $1998 .{ }^{\prime}$

Finalization of the interconnection of the payroll and civil service databases.

Setting up a centralized database to track social outlays and outcomes, in particular for health and education.'

Securitization of the deposits of the Postal Savings Bank (CNE) with the treasury."

Amend the VAT legislation so that henceforth VAT credits would offset VAT liabilities on receipts.

Adopt the administrative and institutional stipulations for the effective operation of the Supreme Audit Court (Cours des Comptes).

Make operational the anti-corruption unit that will be independent of the government and that will have jurisdiction to investigate and review cases and to refer cases to competent judicial authorities ${ }^{1}$
End-December 2000

Done

End-December 2000

Done

End-March 2001

Done

End-March 2001

Done

End-June 2001

Done

End-June 2001

Done

End-September 2001

Done

End-December 2001

End-December 2001

End-December 2001

\footnotetext{
${ }^{1}$ Performance criterion.
} 


\section{INTERNATIONAL MONETARY FUND}

\section{BURKINA FASO}

\section{Technical Memorandum of Understanding}

November 2, 2001

1. This memorandum provides the definitions of the performance criteria and benchmarks of the program supported under the Poverty Reduction and Growth Facility (PRGF) of the International Monetary Fund (IMF). It also sets out the data-reporting requirements for monitoring the program.

\section{DEFinition OF TERMS}

2. For the purpose of this memorandum, the following definitions of "debt," "government," "payment arrears," and "government obligation" will be used:

- As specified in Point 9 of the Guidelines on Performance Criteria with Respect to Foreign Debt adopted by the Executive Board of the IMF on August $24,2000,{ }^{1}$ debt will be understood to mean a current, that is, not contingent, liability, created under a contractual arrangement through the provision of value in the form of assets (including currency) or services, and which requires the obligor to make one or more payments in the form of assets (including currency) or services, at some future point(s) in time; these payments will discharge the principal and/or interest liabilities incurred under the contract. Debts can take a number of forms, the priniary ones being as follows: (i) loans, that is, advances of money to obligor by the lender made on the basis of an undertaking that the obligor will repay the funds in the future (including deposits, bonds, debentures, commercial loans, and buyers' credits) and temporary exchanges of assets that are equivalent to fully collateralized loans under which the obligor is required to repay the funds, and usually pay interest, by repurchasing the collateral from the buyer in the future (such as repurchase agreements and official swap arrangements); (ii) suppliers' credits, that is, contracts where the supplier permits the obligor to defer payments until some time after the date on which the goods have been delivered or services provided; and (iii) leases, that is, arrangements under which property is provided that the lessee has the right to use for one or more specified period(s) of time, which are usually shorter than the total expected service life of the property, while the lessor retains the title to the property. For the purpose of the guideline, the debt is the present value (at the inception of the lease) of all lease payments expected to be made during the period of the agreement, excluding those payments that cover the operation, repair, or maintenance of the property. Under the definition set out above, debt includes arrears, penalties, and judicially awarded

\footnotetext{
${ }^{1}$ See EBS/00/128 (6/30/00: "Limits on External Debt on Borrowing in Fund Arrangements Proposed Changes in Coverage of Debt Limits."
} 
damages arising from the failure to make payment under a contractual obligation that constitutes debt. Failure to make payment on an obligation that is not considered debt under this definition (e.g., payment on delivery) will not give rise to debt. The external debt excludes treasury bills and bonds issued in CFA francs on the regional financial market of the West African Economic and Monetary Union (WAEMU).

- Government is defined as the government of Burkina Faso and does not include any political subdivision or central bank or any government-owned entity with a separate legal personality.

- External payment arrears are external payments due but unpaid. Domestic payment arrears under the program for 2001 and 2002 include domestic payments due (following the expiration of a grace period of 90 days, except where the obligation provides for a specific grace period, in which case that grace period will apply) but unpaid.

- Government obligation is any financial obligation of the government recorded as such by the government (including any government debt).

\section{QUantitative Performance CRITERIA}

\section{A. Cumulative Change in Net Bank Credit to Government and Net Domestic Credit}

\section{Definition - net bank credit to the government}

3. For the purposes of the 2001 program, net bank credit to the government is defined as the balance of the Burkinabè Treasury's claims and debts vis-à-vis national banking institutions. Treasury claims include the cash holdings of the Burkinabè Treasury, deposits with the central bank, deposits with commercial banks, secured obligations, and deposits with the postal system. Treasury debt to the banking system includes funding from the central bank (essentially IMF financing and refinancing of secured obligations), government securities held by the central bank, funding from commercial banks (including government securities held by commercial banks), and funding from the postal system (including deposits of the postal system with the treasury).

4. Government securities held outside the Burkinabè banking system are not included in the net bank credit to the government.

5. Net bank credit to the government is calculated by the Central Bank of West African States (BCEAO), whose figures are those deemed valid within the context of the program.

6. As of June 30, 2001, the net government position thus delined was CFAF 109.3 billion. At that date, the cumulative change on net bank credit to government so defined was CFAF -4.5 billion, compared with the stock at end-December 2000. 


\section{Definition - net domestic credit}

7. Starting in 2002 , the key quantitative performance criterion will be the net domestic credit, defined as the sum of (i) net bank credit to the government, encompassing both the net bank credit to the Burkinabè Treasury as defined above and the other claims and debt of the government vis-à-vis national banking institutions; and (ii) nonbank financing of the government, which includes, inter alia, treasury bills and bonds held outside the national banking institutions and the proceeds of asset sales by the government.

8. Net bank credit to the government is calculated by the BCEAO, whose figures are those deemed valid within the context of the program. The nonbank financing is calculated by the Burkinabè Trcasury, whose figures are deemed valid within the context of the program.

\section{Performance criterion/benchmark}

9. The ceiling on the cumulative change in net bank credit to the government is set at CFAF -5.2 billion at December 31, 2001. This ceiling is a performance criterion at December 31, 2001.

10. The stock of net bank credit to the government, broadly defined, is programmed at CFAF 78.8 billion at end-December 2001. The ceiling on the cumulative change in net domestic credit of the government is projected at CFAF 11.5 billion at March 31, 2002 and CFAF -6.3 billion at June 30, 2002. This target will be set as a benchmark for end-March 2002 and as a performance criterion for end-June 2002 during the fifth review under the arrangement.

\section{Adjustments to performance criterion/benchmark}

11. These ceilings on the cumulative changes in the net bank credit to the government position vis-à-vis the banking system and in net domestic credit will be subject to adjustments if disbursements of external budgetary assistance, including traditional debt relief-but excluding the assistance to be provided under the Initiative for Heavily Indebted Poor Countries (HIPC Initiative) - exceed or fall short of program forecasts. In the event of excess disbursements at the end of each quarter (end-September 2001, end-December 2001, end-March 2002, and cndJune 2002), the ceiling will be adjusted downward pro tanto by the amount of the excess disbursements. In contrast, if at the end of each quarler, disbursements are less than the programmed amounts, the ceiling will be raised pro tanto by the amount of the shortfalls up to the limits (on a noncumulative basis) of a maximum of CFAF 12 billion at end-September 2001, a maximum of CFAF 20 billion at end-December 2001, a maximum of CFAF 1 billion at endMarch 2002, and a maximum of CFAF 20 billion at end-June 2002. Concerning HIPC Initiative assistance granted to Burkina Faso, the savings on the debt service will be lodged in a separate account at the Burkinabè Treasury and used to finance priority programs specified in the poverty reduction strategy paper (PRSP), as defined in the 2001 and 2002 finance laws. 


\section{Reporting requirement}

12. Detailed data on the net government position vis-à-vis the banking system will be provided monthly by the BCEAO within seven wecks following the end of cach month, and those concerning the nonbank financing of the government by the Burkinabè Treasury within the same time frame.

\section{B. Nonaccumulation of Domestic Payment Arrears on Government Obligations}

\section{Definition}

13. Domestic payment arrears on government obligations are reduced through the payment of these obligations as defined under paragraph 2 above. The government undertakes not to accumulate any new domestic payment arrears on government obligations on a net basis. The treasury keeps and updates the inventory of domestic payment arrears on government obligations and maintains records of their repayments.

\section{Performance criterion}

14. The government will not accumulate any domestic payment arrears on government obligations in 2001 and 2002 . The nonaccumulation is a performance criterion for endDeccmber 2001, a benchmark for end-March 2002, and a performance criterion for endJune 2002.

\section{Reporting requirement}

15. Data on the outstanding balance, accumulation, and repayment of domestic payment arrears on government obligations will be provided monthly within four weeks following the end of each month.

\section{Nonaccumulation of External Payment Arrears}

\section{Performance criterion}

16. Government debt is outstanding debt owed or guaranteed by the government. It excludes treasury bills and bonds issued in CFA francs on the WAEMU regional financial market. External payment arrears are debt obligations due but not paid on the due date. Under the program, the government undertakes not to accumulate external payment arrears on government debt, with the exception of external payment arrears arising from government debt being renegotiated with creditors, including Paris Club creditors. The nonaccumulation of external payment arrears on government debt is a performance criterion to be observed continuously.

\section{Reporting requirement}

17. Data on the outstanding balance, accumulation, and repayment of external payment arrears will be provided monthly within four weeks following the end of each month. 


\section{External Nonconcessional Loans Contracted or Guaranteed by the Government of Burkina Faso}

\section{Performance criterion}

18. Under the program, the avoidance of nonconcessional external debt contracted in guaranteed by the government is a continuous performance criterion. Nonconcessional external debt is defined as all external debt with a concessionality level of less than 35 percent. To calculate the level of concessionality for loans with a maturity of at least 15 years, the discount rate to be used is the ten-year average commercial interest reference rate (CIRR) calculated by the IMF, based on the rates published by the OECD; for loans of less than 15 years, the sixmonth average CIRR is used. This performance criterion applies not only to debt as defined in Point 9 of the Guidelines on Performance Criteria with Respect to Foreign Debt, adopted on August 24, 2000, ${ }^{2}$ but also to commitments contracted or guaranteed for which value has not been received. However, this performance criterion docs not apply to financing provided by the Fund, and to treasury notes and bonds issued in CFA francs on the WAEMU regional financial market.

\section{Reporting requirement}

19. Details on any external government debt will be provided monthly within four weeks following the end of each month. The same requirement applics to guarantees extended by the central government.

\section{E. Short-Term External Debt of the Central Government}

\section{Performance criterion}

20. The government will not contract or guarantee external debt with an original maturity of less than one year. The avoidance of external debt with an original maturity of less than one year contracted or guaranteed by the govcrnment is a continuous performance criterion. This performance criterion applies not only to debt as defined in Point 9 of the Guidelines on Performance Criteria with Respect to Foreign Debt, adopted on August 24, 2000, but also to commitments contracted or guaranteed for which value has not been received. Excluded from this performance criterion are short-term, import-related trade credits, and short-term treasury notes issued in CFA francs on the regional financial market. As of June 30, 2001, the government of Burkina Faso had no short-term external debt obligations.

\footnotetext{
${ }^{2}$ See paragraph 2 above.
} 


\section{Structural Performance Criterion}

\section{A. Performance Criterion}

21. The anticorruption unit will be made operational by December 31, 2001. It will be independent of the government and will have jurisdiction to investigate and revicw cases and to refer cases to the competent judicial authorities.

\section{B. Reporting Requirement}

22. The information concerning the implementation of this structural performance criterion will be communicaled to the IMF within two weeks following its scheduled implementation date.

\section{QUANTITATIVE BENCHMARKS}

23. The program also includes quantitative benchmarks on current government revenue, the civil service wage bill, and total current expenditure.

24. Current government revenue is defined as tax revenuc, plus nontax revenue, excluding the revenue collected through treasury checks.

25. Total current expenditure is defined as the difference between total budgetary expenditure, on one hand, and total capital expenditure and net lending, on the other. Capital expenditure is defined as the sum of investment spending identified as such in the national budget and foreign-financed investment outlays.

26. This information will be provided to the IMF monthly within four weeks following the end of each month.

\section{STRUCTURAL BENCHMARKS}

27. The program also includes two structural benchmarks at end-December 2001: the amendment of the value-added tax (VAT) legislation to henceforth deduct VAT credits from receipts; and adoption of the administrative and operational stipulations for the effective operation of the Supreme Audit Court.

\section{ADdTIONAI. INFORMATION FOR PROGRAM-MONITORING PURPOSES}

\section{A. Public Finances}

28. The government will report to IMF staff the following:

- a monthly table of government financial operations (TOFE) and the 13 customary appendix tables, to be provided monthly within three weeks (provisional version) and within six weeks (final version) following the end of each month; if the data on actual public investment financed by external grants and loans are not available in time, a linear estimate based on the annual projection will be adopted; 
- complete monthly data on domestic budgetary financing, to be provided within six weeks following the end of each month;

- quarterly data on implementation of the public investment program, including details on financing sources, to be provided quarterly within six weeks following the end of each quarter;

- monthly data on debt service, to be provided within four weeks following the end of each month;

- monthly data on the taxation of the petroleum sector, including (i) the price structure prevailing during the month; (ii) the detailed calculation of the price structure, going from the f.o.b.-MED price to the retail price; (iii) the volumes purchased and supplied to the domestic market by the petroleum distributor (SONABHY); and (iv) the breakdown of receipts from the taxation of petroleum products - customs duties, tax on petroleum products (TPP), and value-added tax (VAT) - and of subsidies, to be provided monthly within four weeks following the end of each month;

- monthly data on the resources and use of the Burkinabè Treasury's special account created for the use of the resources from the debt-service savings under the HIPC Initiative, to be provided monthly within six weeks following the end of each month; and

- the status of all the deposit accounts at the treasury classified by major category (administrative scrvices, statc enterprises, mixed enterprises, public administrative enterprises, international organizations, private depositors, and others), to be provided within four weeks following the end of each month.

\section{B. Monetary Sector}

29. The government will provide the following information within eight wccks following the end of each month:

- the consolidated balance sheet of monetary institutions and, if the need arises, details pertaining to individual banks;

- the monetary survey, seven weeks after the end of each month for provisional data, and ten weeks after the end of each month for final data;

- borrowing and lending interest rates; and

- customary banking supervision indicators for bank and nonbank financial institutions-as needed, indicators for individual institutions may also be provided.

\section{Balance of Payments}

30. The government will provide the following information:

- any revision to balance of payments data (including services, private transfers, official transfers, and capital transactions) whenever they occur; and

- preliminary annual balance of payments data, within nine months following the end of the year concerned. 


\section{Real Sector}

31. The government will provide the following information:

- disaggregated monthly consumer price indices, monthly within two weeks following the end of each month;

- provisional national accounts, no later than six months after the end of the year; and

- any revision in the national accounts.

\section{E. Structural Reforms and Other Data}

32. The government will provide the following information:

- any study or official report on Burkina Faso's economy, within two weeks following its publication; and

- any decision, order, law, decree, ordinance, or circular with economic or financial implications, upon its publication or, at the latest, when it enters into force. 


\section{F. Summary of Main Data Requirements}

\begin{tabular}{|c|c|c|c|}
\hline Type of Data & Tables & Frequency & Reporting Lag \\
\hline \multirow[t]{3}{*}{ Real sector } & Provisional national accounts & Annual & Six months after year's end \\
\hline & Revisions of national accounts & Ad hoc & $\begin{array}{l}\text { Eight weeks following } \\
\text { revision }\end{array}$ \\
\hline & Disaggregated consumer price index & Monthly & End of month + two weeks \\
\hline \multirow[t]{6}{*}{ Public finances } & $\begin{array}{l}\text { Net treasury and government at large } \\
\text { position with the central bank, and } \\
\text { details of nonbank financing }\end{array}$ & Monthly & End of month + six weeks \\
\hline & $\begin{array}{l}\text { Table of government financial } \\
\text { operations (TOFE) and the } 13 \text { usual } \\
\text { appendix tables }\end{array}$ & Monthly & $\begin{array}{l}\text { End of month }+ \text { three weeks } \\
\text { (provisional) } \\
\text { End of month }+ \text { six weeks } \\
\text { (final) }\end{array}$ \\
\hline & Execution of investment budget & Quarterly & End of quarter + six weeks \\
\hline & $\begin{array}{l}\text { Petroleum product pricing formula, tax } \\
\text { receipts on petroleum products, and } \\
\text { subsidies paid }\end{array}$ & Monthly & End of month + four weeks \\
\hline & $\begin{array}{l}\text { Status of the special account at the } \\
\text { Burkinabe Treasury handling the use of } \\
\text { the HIPC Initiative resources }\end{array}$ & Monthly & End of month + six weeks \\
\hline & $\begin{array}{l}\text { Status of the deposit accounts at the } \\
\text { Burkinabè Treasury classified by major } \\
\text { category }\end{array}$ & Monthly & End of month + four weeks \\
\hline \multirow[t]{5}{*}{$\begin{array}{l}\text { Monetary and } \\
\text { financial data }\end{array}$} & Monetary survey & Monthly & $\begin{array}{l}\text { End of month }+ \\
\text { seven weeks (provisional) }\end{array}$ \\
\hline & & & $\begin{array}{l}\text { End of month }+ \text { ten weeks } \\
\text { (final) }\end{array}$ \\
\hline & $\begin{array}{l}\text { Consolidated balance sheet of } \\
\text { monetary institutions and, as needed, } \\
\text { balance sheets of individual banks }\end{array}$ & Monthly & End of month + eight weeks \\
\hline & Borrowing and lending interest rates & Monthly & End of month + eight weeks \\
\hline & Banking supervision ratios & Quarterly & $\begin{array}{l}\text { End of quarter }+ \\
\text { cight wecks }\end{array}$ \\
\hline \multirow[t]{2}{*}{ Balance of payments } & Balance of payments & Annual & End of year + nine months \\
\hline & Revised balance of payments data & Ad hoc & When revisions occur \\
\hline \multirow[t]{2}{*}{ External debt } & $\begin{array}{l}\text { Outstanding external payment arrears } \\
\text { and repayments (if applicable) }\end{array}$ & Monthly & End of month + six weeks \\
\hline & Details of new external borrowing & Monthly & End of month + six weeks \\
\hline
\end{tabular}




\section{Burkina Faso: Relations with the Fund}

(As of September 30, 2001)

I. Membership Status: Joined: 05/02/63; Article VIII

II. General Resources Account:

SDR Million

60.20

52.98

Fund Holdings of Currency

Reserve position in Fund

III. SDR Department:

Net cumulative allocation

Holdings

IV. Outstanding Purchases and Loans:

Enhanced Structural Adjustment Facility (ESAF)

Poverty Reduction and Growth Facility (PRGF)

arrangements
7.23

SDR Million

9.41

0.45

SDR Million

91.31
$\%$ Quota

100.0

88.0

12.0

\%Allocation
100.0
4.8

$\%$ Quota

151.7

V. Financial Arrangements:

$\begin{array}{ccccc}\text { Type } & \begin{array}{c}\text { Approval } \\ \text { Date }\end{array} & \begin{array}{c}\text { Expiration } \\ \text { Date }\end{array} & \begin{array}{c}\text { Amount Approved } \\ \text { (SDR Million) }\end{array} & \begin{array}{c}\text { Amount Drawn } \\ \text { (SDR Million) }\end{array} \\ \text { PRGF } & 09 / 10 / 1999 & 09 / 09 / 2002 & 39.12 & 22.36 \\ \text { ESAF } & 06 / 14 / 1996 & 09 / 09 / 1999 & 39.78 & 39.78 \\ \text { ESAF } & 03 / 31 / 1993 & 05 / 30 / 1996 & 53.04 & 44.20\end{array}$

VI. Projected Obligations to Fund: (SDR Million; based on existing use of resources and present holdings of SDRs):

Overdue $\underline{04 / 30 / 2001}$

\begin{tabular}{|c|c|c|c|c|}
\hline \multicolumn{5}{|c|}{ Forthcoming } \\
\hline$\underline{2001}$ & $\underline{2002}$ & $\underline{2003}$ & $\underline{2004}$ & $\underline{2005}$ \\
\hline 5.1 & 10.8 & 12.6 & 13.5 & 11.7 \\
\hline 0.3 & 0.7 & 0.7 & 0.6 & 0.5 \\
\hline 5.4 & 11.5 & 13.3 & 14,1 & 12.2 \\
\hline
\end{tabular}


Burkina Faso: Relations with the Fund

\section{Implementation of HIPC Initiative:}

\begin{tabular}{|c|c|c|c|}
\hline & $\begin{array}{c}\text { Original } \\
\text { framework }\end{array}$ & $\begin{array}{l}\text { Enhanced } \\
\text { framework }\end{array}$ & Total \\
\hline \multicolumn{4}{|l|}{ Commitment of HIPC assistance } \\
\hline Decision point date & $9 / 8 / 1997$ & $7 / 10 / 2000$ & \\
\hline \multicolumn{4}{|l|}{ Assistance committed (end-1999 NPV terms) } \\
\hline Total assistance (US\$ million) & 229 & 169 & \\
\hline Of which: Fund assistance (SDR million) & 16.3 & 15.0 & \\
\hline Complction point date & $7 / 10 / 2000$ & Floating & \\
\hline \multicolumn{4}{|l|}{ Delivery of Fund assistance (SDR million) } \\
\hline Amount disbursed & 16.3 & 3.2 & 19.5 \\
\hline Interim assistance & $\ldots$ & 3.2 & 3.2 \\
\hline Completion point & 16.3 & 0 & 16.3 \\
\hline $\begin{array}{l}\text { Amount applied against member's obligations } \\
\text { (cumulative) }\end{array}$ & 2.9 & 1.9 & 4.8 \\
\hline
\end{tabular}

VII. Safeguards Assessments:

Under the Fund's safeguards assessment policy, the Central Bank of the West African States (BCEAO), of which Burkina Faso is a member, is subject to a full Stage One safeguards assessment. A Stage One safeguards assessment of the BCEAO was completed on July 25, 2001. The assessment concluded that high risks may exist in BCEAO's financial reporting framework, but did not draw conclusions on the bank's internal audit mechanism nor the internal controls structure. The assessment recommended an on-site fact-finding mission, which took place October 15-24, 2001.

\section{Exchange Rate Arrangement:}

Starting on January 1, 1999, Burkina Faso's currency, the CFA franc, has been pegged to the euro at the rate of $€ 1=$ CFAF 655.95 . The exchange rate on September 28, 2001 was CFAF $925.99=$ SDR 1 . The exchange and trade system is free of restrictions on payments and transfers on current international transactions. 


\section{Burkina Faso: Relations with the Fund}

\section{Article IV Consultations:}

Burkina Faso is on the standard 12-month consultation cycle. The 2001 Article IV discussions and the third review under the Poverty Reduction and Growth Facility (PRGF) were held during the period April 10-25, 2001 in Ouagadougou. The staff report (EBS/01/84; 6/13/01) and the statistical annex (SM/01/176; 6/19/01) were considered by the Executive Board on July $2,2001$.

\section{ROSC/AAP:}

An FAD mission visited Ouagadougou during May 7-18, 2001, to assist the authorities undertake a draft fiscal module of a Report on the Observance of Standards and Codes (ROSC). The mission found that Burkina Faso is making good progress in a number of areas to increase the transparency and accountability of government. But additional efforts are needed to bring a number of improvements to the point of implementation, particularly with regard to expenditure tracking at the local level and external audit functions. Initial discussions indicated that the authorities were in broad agreement with the mission assessment. The report is currently being completed.

The team, jointly with World Bank staff, also discussed a HIPC Assessment and Action Plan (AAP) with the authorities. The aim was to assess the capacity of the public expenditure management system to track poverty-reducing public expenditures under the HIPC Initiative and the need for technical assistance to enhance that capacity. The mission secured officials' agreement with the jointly prepared preliminary assessment; identified the main needs for technical assistance on upgrading the capacity to track such expenditures; and drew up a draft outline Action Plan. This plan identifies the main needs for further technical assistance to improve tracking of poverty-reducing expenditures. The AAP has been communicated to the World Bank and will be finalized as soon as their comments are received.

\section{Technical Assistance:}

Significant technical assistance has been provided since 1989, especially in fiscal area, more recently:

\section{Department Type of Assistance Time of Delivery}

FAD Staff $\quad$ October 6-17, 1997

\section{Purpose}

Assessing the fiscal impact of the common external tariff (CET) and regional integration, and defining policies to offset revenue losses. 


\section{Burkina Faso: Relations with the Fund}

FAD Staff November 20-30, 1998

$\mathrm{FAD}$

Staff

February 11-25, 1999

FAD

FAD

Staff
May 7-18, 2001
Assessing implementation of the 1997 mission recommendations, and proposing complementary reforms to strengthen the fiscal and customs administrations.

Assisting in upgrading the computer system used for large taxpayers and following up on the implementation of previously recommended measures.

December 4-11, 1999 Monitoring the upgrading of the computer system used for large taxpayers; reviewing the establishment of a withholding system for business taxes; reviewing the system of treasury refunds of taxes due on foreign-financed projects; and proposing modalities for eliminating value-added tax exemptions on investments.

Assisting in completion of the fiscal module of the Report on the Observance of Standards and Codes (ROSC), and drafting assessment of an action plan, the capacity of the public expenditure management system to track and report on the uses of HIPC Initiative assistance and all poverty-reducing expenditures.

\section{Resident Representative:}

Mr. Robert Franco took up the post of Resident Representative in early December 2000 . 


\section{Burkina Faso: Relations with the World Bank Group}

(As of August 31, 2001)

Since the beginning of the structural reforms in the early 1990s, the World Bank has approved, in addition to project support, two structural adjustment credits, an economic recovery credit, an agricultural sector adjustment credit, a transport adjustment credit, and an economic management reform credit. The current portfolio amounts to commitments of US $\$ 390.1$ million, of which US $\$ 268.8$ million is undisbursed. It includes a number of projects aimed at accelerating the provision of social services, with one project in the education sector, one in health/nutrition, two in population/AIDs control, one in the water sector, and one in urban environment. Other projects are geared to improving agriculture (such as Community based rural development, AG services and Private Irrigation), supporting the poverty reduction strategy of the Burkina Faso's government (Poverty Reduction Support Credit I) and building up capacity in the mining sector (see table). Forty-eight IDA credits for an amount of US\$748.6 million have been closed. There are no MIGA operations in Burkina Faso.

\section{New credits}

Two operations have been approved so far in FY2002 (PRSC I and HIV/AIDS). Four more operations are expected to be approved in fiscal-year 2002: one Poverty Reduction Support Credit (PRSC); a Basic Education operation; a Competitiveness and Enterprise Development operation; and a Supplemental Urban operation.

\section{Statement of IDA Credits}

(In millions of U.S. dollars)

\begin{tabular}{lrlrr}
\hline $\begin{array}{l}\text { Credit } \\
\text { Number }\end{array}$ & $\begin{array}{l}\text { Fiscal } \\
\text { Year }\end{array}$ & \multicolumn{1}{c}{ Sector } & IDA & Undisbursed \\
C25950-BF & 1994 & Health/Nutrition & 29.2 & 1.6 \\
C26190-BF & 1994 & Population/AIDS Control & 26.3 & 3.1 \\
C27280-BF & 1995 & Urban Environment & 37.0 & 10.6 \\
CN0070-BF & 1997 & Post-Primary Education & 26.0 & 13.7 \\
CN0290-BF & 1997 & Mining Capacity Building & 21.4 & 12.5 \\
C29740-BF & 1998 & AG Services II & 41.3 & 24.8 \\
C31610-BF & 1999 & Private Irrigation & 5.2 & 3.3 \\
C34360-BF & 2001 & Community-Based Rural Devlpt, & 66.7 & 63.3 \\
C34760-BF & 2001 & Ouagadougou Water Supply & 70.0 & 68.9 \\
C35570-BF & 2002 & HIV/AIDS Disaster Response & 22.0 & 22.0 \\
C35650-BF & 2002 & Poverty Reduction Support Credit & 45.0 & 45.0 \\
Total (number of credits: 11$)$ & & 390.1 & 268.8 \\
& & & & \\
48 credits closed & & & 748.6 & 0.0
\end{tabular}

Source: World Bank. 


\section{Burkina Faso: Statistical Issues}

In January 2001, Burkina Faso formally adopted the General Data Dissemination System (GDDS) as its statistical development framework, and a country coordinator has been named. During the GDDS workshop in Bamako in March-April 2001, draft GDDS metadata were prepared for all five sectors including plans for improvements. After being reviewed by STA, the final report has becn forwarded to the Council of Ministers for adoption and will thereafter be posted on the Fund's website. Following the conversion of the Statistical Institute into an autonomous agency, its allocations in human and material resources will be significantly raised in the 2002 budget.

\section{Real sector}

While the general framework of the national accounts is rather complete, there are substantial problems with the source data for the national accounts at current prices and the price statistics used as deflators. In particular, the industrial production index should be updated to include new industrial units. Also, the procedure to collect information on private investment and services should be improved. In addition, the national accounts suffer from methodological problems.

The base year of the constant price national accounts estimates has been updated from 1979 to 1985, resulting in revisions in the data from 1985 onwards. The final 1993-97 national accounts were published in May 2000. The index of industrial production is under revicw, within the framework of a program harmonized at the level of the West African Econornic and Monetary Union (WAEMU); a new industrial census, taken in March 1998, will be used in the construction of the new index.

A new consumer price index was published in 1998, based on a survey taken in the context of a regional project financed by the European Union and France. The coverage of this index will gradually be extended to include markets outside Ouagadougou. A new household survey completed in 1999 provides detailed information on the incidence of poverty and expenditure palterns.

\section{Government finance}

The last summary annual data published in International Financial Statistics are for 2000 . No detailed data have been reported for the past five years to STA; hence the 2000 Government Finance Statistics (GFS) Yearbook covers only 1984-93, with limited details and coverage (and the data relate only to budget operations and capital expenditures financed through grants. No data are reported on extrabudgctary and social security operations, as well as on operations financed by foreign loans). The compilation of GFS is constrained by a lack of coordination among fiscal agencies, which has a negative impact on the reliability and timeliness of these data. 


\section{Monetary accounts}

Preliminary monetary data for Burkina Faso are prepared by the national agency of the Central Bank of West African States (BCEAO) and released officially by the headquarters of the BCEAO with a lag of two to three months. An accounting system for commercial banks was introduced by the BCEAO on January 1, 1996. Most of the problems that appear in the monetary statistics for Burkina Faso are not specific to that country but concern all countries of the WAEMU. ${ }^{1}$ One statistical problem arises from the difficulties the BCEAO has encountered in estimating currency in circulation in each WAEMU member country because of the large backlog of unsorted banknotes held by the central bank in its various national agencies. A money and banking statistics mission visited the BCEAO in August 1997, investigated these problems, and reviewed with the authorities several measures that would contribute to reducing the delay. The BCEAO is working on additional measures to accelerate the sorting operations in order to resolve this problem.

A second problem has been the slower-than-expected implementation of the new accounting system by banks since its introduction in 1996. These delays contribute importantly to the lag in reporting monetary statistics. The August 1997 STA mission that visited the BCEAO recommended that timing targets for reducing delays in producing the principal report forms be established. The situation has improved recently, and data for the monetary authorities and deposit money banks have been provided to STA through May 2001. While there has been a recent reduction in the lag in reporting monetary data to STA, among others-and this appears to reflect in part an acceleration in this phase of statistical production-there is scope for further improvement.

A monetary and financial statistics mission visited the headquarters of the BCEAO in May 2001. The mission reviewed the procedures for collecting and compiling monetary statistics, and addressed the outstanding methodological issues that concern all the member countries of the WAEMU. A technical memorandum on the mission's main findings and recommendations will be sent to the BCEAO authorities upon finalization.

\section{Balance of payments}

The BCEAO is responsible for completing the balance of payments statistics that have significantly improved over the past few years.. The technical assistance of STA (a Statistical Advisor was posted at the BCEAO headquarters in Dakar from July 1996 through July 1999) contributed to the reporting of yearly balance of payments data in line with the framework of the Balance of Payments Manual, (Fifth Edition (BPMS) for the period 1996-99. In addition, the BCEAO disseminated the 1988-95 data in the BPMS format. Regarding trade data, the customs computer system (SYDONIA) was upgraded in 1999, and its installation in the main border customs houses is being completed; this should allow a better monitoring of import data and

${ }^{1}$ Benin, Burkina Faso, Côte d'Ivoire, Guinea-Bissau, Mali, Niger, Senegal, and Togo. 
should improve the coverage of informal trade. The further improvement of services and transfers (especially workers' remittances) coverage is clcarly linked to the intensification of the contacts with reporting bodies; this implies that the authorities' commitment to strengthen the human and technical resources should be confirmed.

Conccrning the financial account, the foreign assets of the private nonbanking sector are still weakly covered, especially assets of WAEMU residents, which are assessed through the Bank for International Settlement (BIS) data. The organization of annual exhaustive surveys for the reporting of foreign direct investment transactions in Burkina Faso is still at a very preliminary stage. The BCEAO authorities have indicated that they are looking forward to integrating two additional sources aimed at improving the quality of the balance of payments reports: the regional stock exchange transactions, and the firms' balance sheet database (centrale des bilans).

The follow-up mission at the BCEAO headquarters (April 17-28, 2000) highlighted improvements in released data: early in 2000, Burkina Faso approved a balance of payments final statement for 1998. However, the mission pointed out serious shortages in the human and technical resources that hampered the implementation of the resident advisor's recommendations.

The computer debt-management system softwarc, SYGADE, developed by the United Nations Conference on Trade and Development (UNCTAD), was introduced in 1999 and is fully operational. Information on debt disbursement has also been fully integrated with the expenditure monitoring system. 
Burkina Faso: Core Statistical Indicators

(As of October 22, 2001)

\begin{tabular}{|c|c|c|c|c|c|c|c|c|c|c|c|c|}
\hline & $\begin{array}{c}\text { Exchange } \\
\text { Rates }\end{array}$ & $\begin{array}{l}\text { Internationai } \\
\text { Reserves }\end{array}$ & $\begin{array}{c}\text { Rescrve/ } \\
\text { Base } \\
\text { Money }\end{array}$ & $\begin{array}{l}\text { Central } \\
\text { Bank } \\
\text { Balance } \\
\text { Shcet }\end{array}$ & $\begin{array}{l}\text { Broad } \\
\text { Money }\end{array}$ & $\begin{array}{l}\text { Interest } \\
\text { Rates 1/ }\end{array}$ & $\begin{array}{l}\text { Consumer } \\
\text { Price } \\
\text { Index }\end{array}$ & $\begin{array}{l}\text { Exports/ } \\
\text { Imports } 2 /\end{array}$ & $\begin{array}{l}\text { Current } \\
\text { Account } \\
\text { Balance }\end{array}$ & $\begin{array}{c}\text { Overali } \\
\text { Govern- } \\
\text { ment } \\
\text { Balance }\end{array}$ & GDP/GNP 3/ & $\begin{array}{l}\text { Exicrnal } \\
\text { Debt }\end{array}$ \\
\hline $\begin{array}{l}\text { Date of latest } \\
\text { Observation }\end{array}$ & 09/30/01 & July 2001 & July $200 \mathrm{l}$ & July 2001 & July 2001 & Sepl. 2001 & Sept. 2001 & Aug 200 & Dec. 2000 & Oct. 2001 & 2000 & June 2001 \\
\hline Date received & $09 / 30 / 01$ & Oct. 2001 & Oct. 2001 & Oct. 2001 & Oct. 2001 & Sept. 2001 & Oct. 2001 & Oct. 2001 & April 2001 & Sept. 2001 & April 200I & Sept. 2001 \\
\hline Frequency of data & Daily & Monthly & Monthly & Monthly & Monthly & Monthly & Monthly & Monthly & Annual & Monthly & Annually & Annual \\
\hline $\begin{array}{l}\text { Frequency of } \\
\text { reporting }\end{array}$ & Daily & Monthly & Monthly & Monthly & Monthly & Monthly & Monthly & Quarterly & Annually & Monthly & Annually & Annually \\
\hline Source of data $4 /$ & EIS/TRE & BCEAO & BCEAO & BCEAO & BCEAO & BCEAO & BCEAO & BCEAO & BCEAO & $\begin{array}{l}\text { Ministry of } \\
\text { Finance }\end{array}$ & $\begin{array}{l}\text { Ministry of } \\
\text { Finance }\end{array}$ & $\begin{array}{l}\text { Ministry of } \\
\text { Finance }\end{array}$ \\
\hline Mode of reporting & On-line & Staff /e-naail & Staff/e-mail & Staff/e-mail & Staff/e-mail & Staff/e-mail & Electronic & Electronic & Staff & Staff & Staff & Staff \\
\hline Confidentiality & No & $5 /$ & $5 t$ & $5 /$ & $5 t$ & No & No & $5 /$ & $5 /$ & $5 /$ & $5 l$ & $5 /$ \\
\hline $\begin{array}{l}\text { Frequency of } \\
\text { publication }\end{array}$ & Daily & Monthly & Monthiy & Monthly & Monthly & Monthly & Monthly & Annually & Annually & Monthly & Annt & Ann \\
\hline
\end{tabular}

1/ Up-to-date data available upon request from BCEAO; also updated regularly in press.

2/ Customs data available monthly in conjunction with fiscal data.

3/ Revised periodically during year.

4/ EIS = IMF, Economic Information System; TRE = IMF, Trcasurer's Department; BCEAO = Central Bank of West African States.

5/ Preliminary use for staff only; actual data unrestricted. 
Burkina Faso: Tentative Work Program Under the PRGF Arrangement, 2000-02

\begin{tabular}{l}
\hline \multicolumn{1}{c}{ Date } \\
July 10,2000 \\
October $24-$ November 8, \\
2000
\end{tabular}

End-December 2000

January 10, 2001

April 10 - April 25, 2001

July 2, 2001

End-June 2001

September 3-19, 2001

November 30, 2001

End-December 2001

February 2002

Executive Board conclusion of the 2000 Article IV consultation, completion of the first review under the PRGF arrangement, and approval of completion point for the original HIPC Initiative, second decision point for the enhanced HIPC Initiative, and consideration of the PRSP and its asscssment

Mission on the second review under the PRGF arrangcment and on the negotiation of the second annual program under the PRGF arrangement

Performance criteria test date for the fourth loan

Executive Board completion of the second review under the PRGF arrangement

Disbursement

Mission on the third review under the PRGF arrangement and discussions of the 2001 Article IV consultation

Executive Board discussion of the 2001 Article IV consultation and the third review under the PRGF arrangement

Performance criteria test date for the fifth loan

Mission on the fourth review under the PRGF arrangement, discussion of the third annual program under the PRGF arrangement, completion point under the enhanced HIPC Initiative, and assessment of the progress report of the PRSP

Executive Board consideration of the fourth review under the PRGF arrangement, and assessment of the progress report of the PRSP

SDR 5.59 million

Performance criteria test date for the sixth loan

Mission on the fifth review under the PRGF arrangement and discussions of the 2002 Article IV consultation

March 2002

Executive Board discussion of the 2002 Article IV

Consultation, completion point under the cnhanced HIPC Initiative, and consideration of the fifth review under the PRGF arrangement

End-June 2002

Performance criteria test date for the seventh loan

August 2002

Sixth review under the PRGF arrangement and final disbursement

SDR 5.59 million

SDR 5.59 million

SDR 5.59 million

SoR 5.59 million

SDR 5.59 nillion

SDR 5.59 million Expiration of the arrangement 


\section{Downside Risk Scenario}

\section{Exogenous shocks}

During the year 2000, the Burkinabè economy was hit by exogenous shocks that affected growth. For the period 2002-05, a downside risk scenario was prepared. Its purpose is to measure the impact on macrocconomic variables of two types of exogenous shocks, thereby highlighting the fragility of the Burkinabè economy:

- Bad weather conditions. Cereals and cotton are very sensitive to the level and timing of the rain, as shown by a drop of 15 percent in cereal production in 2000 . After abundant rainfalls in 2001 , the downside risk scenario assumes a 20 percent decline in the growth rate of the primary sector compared with the baseline scenario, from 4.2 percent to 3.4 percent per year.

- Lower level of workers' remittances from Côte d'Ivoire. The drop in workers' remittances experienced in 2000 and 2001 is assumed to continuc during 2002-05.

These shocks will have a negative impact on real GDP growth (Box 1), fiscal variables (Appendix VI, Table 1) and the balance of payments (Appendix VI, Table 2).

\section{Real GDP growth}

Box 1. Real GDP Growth in the Baseline Scenario and Downside Risk Scenario

(In percent)

\begin{tabular}{lrrrrr}
\hline & 2001 & 2002 & 2003 & 2004 & 2005 \\
\hline Real GDP growth-baseline scenario & 6.2 & 5.8 & 5.7 & 5.5 & 5.5 \\
Real GDP growth—downside risk & 6.2 & 4.9 & 4.6 & 4.5 & 4.6
\end{tabular}

Under the above-mentioned assumptions, real GDP growth is expected to be slightly higher than 4 percent over the period, that is, about 1 percentage point lower than under the baseline scenario. Growth in the primary sector reaches 3.4 percent over 2002-05. Bad performance in agriculture production and a low level of workers' remittances will lead to a decrease in the demand for secondary and tertiary goods and services.

\section{Fiscal outcomes}

Throughout the period 2002-05, tax revenue decreases compared with the baseline scenario (CFAF 2.3 billion in 2002 and CFAF 13.2 billion in 2005), as a result of the lower real growth. The level of expenditure is assumed to remain unchanged from the baseline scenario. The financing gap will fluctuate from 0.1 percent of GDP in 2001 to 0.6 percent of GDP in 
2005. Such gaps remain manageable and financeable through a mix of domestic adjustment and somewhat higher financing.

\section{Balance of payments}

The contraction of imports because of the lower growth is more than offset by lower exports of cotton and a lower level of workers' remittances, thereby worsening the current account deficit over the period 2003-05 by about 0.8 percentage point of GDP annually more than in the baseline scenario. 
Table 1. Burkina Faso: Consolidated Operations of the Central Goveriment. 1999.2005

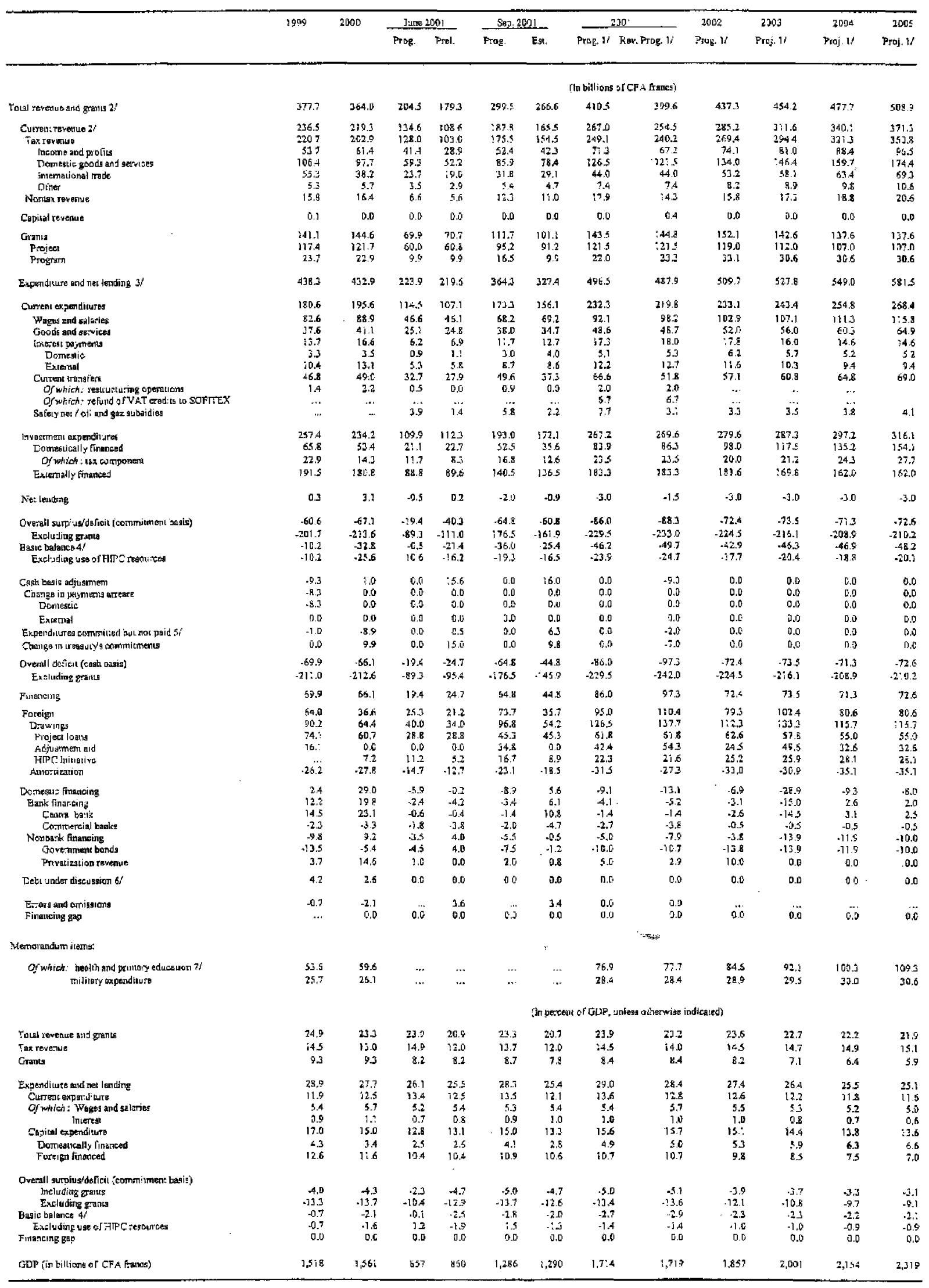

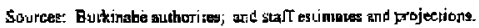

Ii hrecludes FiPC initipive resaurzes,

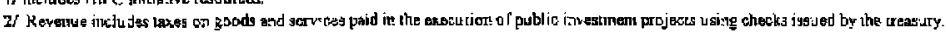

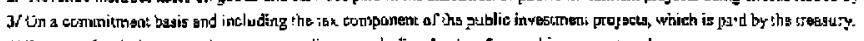

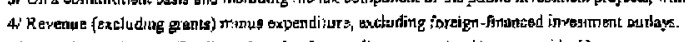

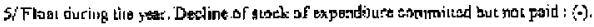

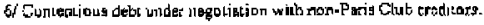

7/ Excludiag foreigat-finanoed investments. 
Table 2. Burkina Faso: Bailance of Paymenes, 1999-2021

\begin{tabular}{|c|c|c|c|c|c|c|c|c|}
\hline & \multirow[t]{2}{*}{1949} & \multirow[t]{2}{*}{2000} & \multicolumn{2}{|c|}{2001} & \multirow[t]{2}{*}{2002} & \multirow{2}{*}{$\frac{2003}{\text { ections. l' }}$} & \multirow[t]{2}{*}{2004} & \multirow[t]{2}{*}{2005} \\
\hline & & & Prog. & Proj. J/ & & & & \\
\hline & \multicolumn{8}{|c|}{ (In billiuns of ClA franess) } \\
\hline Exports, f.o.b. & 156.2 & 1451,4 & 178.8 & 177.0 & 200.2 & 215.8 & 235.5 & 251.6 \\
\hline of which: colton & 83.6 & 72.4 & 94.1 & 95.6 & 116.9 & 125.9 & 141.3 & 1493 \\
\hline gould & 9.2 & 6.2 & 5.8 & 6.5 & 6.0 & 6.0 & 6.0 & 6.3 \\
\hline Imports, f.o.b. & -357.4 & -368.6 & -396.9 & -407.5 & -392.0 & -402.8 & -420.4 & .445 .6 \\
\hline of which- capital goods & -125.0 & -122.8 & -138.9 & -141.6 & -135.0 & -127.8 & -124.2 & -124.3 \\
\hline Ttade balance & -201.2 & .222 .2 & -218.1 & .230 .5 & -191.8 & -187.0 & -184.9 & -194.0 \\
\hline Services and income (Jel) & -820 & -86.5 & -91.0 & -93.8 & $-90,6$ & $-9] .6$ & $-94,3$ & .99 .1 \\
\hline Services & -70.8 & -72.6 & -77.9 & -80.0 & -77.8 & -80.0 & -83.3 & -87.9 \\
\hline Income & -11.3 & -14.0 & -13.1 & -13.8 & .12 .8 & -11.7 & -11.0 & -11.2 \\
\hline Of which: interest payments & $-1], 1$ & .13 .8 & -12.8 & -13.4 & -12.3 & -10.9 & -100 & -10.0 \\
\hline Of witich bodget & -10.4 & $-13 . J$ & -12.2 & -12.6 & -11.5 & -10.2 & -9.3 & -11.7 \\
\hline Cument transiers (net) & 88.7 & 85.2 & 82.3 & 84.2 & 91.5 & 92.6 & 96.5 & 100.7 \\
\hline Private & 39.7 & 29.9 & 20.3 & 20.1 & 14.7 & $\$ 5.4$ & 16.1 & 16.9 \\
\hline Of which : workers' renittances (gross) & 50.3 & 41.0 & 30.0 & 30.0 & $24 n$ & 24.0 & 24.0 & 24.0 \\
\hline Official & 48.9 & 55.3 & 62.1 & 64.1 & 76.8 & 77.3 & 80.4 & 83.8 \\
\hline Of which: budgetury (program grants) & 23.7 & 22.9 & 22.0 & 23.3 & 33.1 & 30.6 & 30.6 & 30.6 \\
\hline Current ilcsount (cterejcil= -) & -194.6 & -223.5 & -226.7 & -240.1 & .190 .9 & -186.0 & -182.7 & -192.3 \\
\hline Excluding current officiel transfers & -243.5 & -278.8 & -288.8 & -.304 .2 & .267 .7 & -263.3 & -263.1 & -276.1 \\
\hline Capical transfers & 120.4 & 124.7 & 124.5 & 124.5 & $\mathrm{~J} 22.0$ & 115.1 & 110.3 & 110.4 \\
\hline Project grants & 117.4 & 121.7 & 121.5 & 121.5 & 119.0 & 112.0 & 107.0 & 107.0 \\
\hline Other capital transfers & 3.0 & 3.0 & 3.0 & 3.0 & 3.0 & 3.1 & 3.3 & 3.4 \\
\hline Firtantcial opterations & 69.5 & 51.6 & 85.2 & 94.8 & 61.4 & 84.3 & 61.0 & 61.7 \\
\hline Official capital & 64.0 & 29.4 & 70.4 & 86.4 & 52.4 & 74.7 & 50.7 & 50.8 \\
\hline DisbursemenLs & 90.2 & 60.7 & 104.2 & 116,1 & 87.1 & 107.4 & 87.6 & 87.6 \\
\hline Project loans & 74.2 & 60.7 & 61.8 & 61.8 & 62.6 & 57.8 & 55.0 & 55.0 \\
\hline Program loans & 16.1 & 0.0 & 42.4 & 54.3 & 24.5 & 49.6 & 32.6 & 32.6 \\
\hline Arnortizalion & -26.2 & -31.3 & -33.8 & -29.7 & -34.7 & -32.7 & -36.9 & -36.8 \\
\hline Of which budget & -26.2 & -27.8 & .31 .5 & -27.3 & .33 .0 & -30.9 & -35.1 & -35.1 \\
\hline Private ca lital $2 /$ & 5.4 & 22.2 & 14.8 & 8.4 & 9.0 & 9.6 & 10.2 & 10.9 \\
\hline Ertory and umissions & -8.6 & 6.9 & 0.0 & 00 & 0.0 & 0.0 & 0.0 & 0,0 \\
\hline Overall balance & -13.3 & -40.3 & -17.1 & .20 .8 & -7.5 & $1,3.4$ & -11.4 & -20.2 \\
\hline Financing & 13.3 & 40.3 & 17.1 & 20.8 & 7.5 & -13.4 & 11.4 & 20.2 \\
\hline Nêl forcign assets & 9.1 & 30.5 & .5 .2 & -0.8 & .20 .0 & $-45,2$ & -26.2 & -19.8 \\
\hline Net official reserves & 21.5 & 28.7 & .5 .2 & -0.8 & -20.0 & $-45,2$ & .26 .2 & -19.8 \\
\hline Gross of ficial reserves & 14.6 & 30.5 & -11.3 & -7.1 & -20.3 & 34.2 & $-14 . .3$ & -9.5 \\
\hline IMF (net) & 7.0 & -1.7 & 6.1 & 6.3 & 0.3 & -11.1 & -11.9 & -10.3 \\
\hline Use of resoures & 10.3 & 5.2 & 15.3 & 15.9 & 9.8 & 0.0 & 0.0 & 0.0 \\
\hline Repaymen1s & $-3,3$ & -7.0 & -9.3 & -9.6 & -9.5 & -31.1 & -11.9 & -10.3 \\
\hline Nel foreign assets, commercial banks & -12.4 & 1.7 & 0.0 & 0.0 & 0.0 & 0.0 & 0.0 & 0.0 \\
\hline Change in arrwars (rorlucrion= -) & 0.0 & 0.0 & 0.0 & 0.0 & 0.0 & 0.0 & 0.0 & 0.0 \\
\hline IJPCC Initiative & 0.0 & 7.2 & 22.3 & 21.6 & 25.2 & 25.9 & 28.1 & 26.2 \\
\hline Debt under discussion, $3 /$ & 4.2 & 2.6 & 0.0 & 0.0 & 0.0 & 0.0 & 0.0 & 0.0 \\
\hline Fiscal fiuancing gap & 0.0 & 0.0 & 0.0 & 0.0 & 2.4 & 5.9 & 9.5 & 13.8 \\
\hline Memoriandum items: & \multicolumn{8}{|c|}{ (In prencem of CDP, unless otherwise specified) } \\
\hline Trade balance (deficit= -) & -13.3 & -14.2 & -12.7 & -13.4 & -10.4 & -9.5 & -8.9 & -8.7 \\
\hline Cotton export volurste (thnusands of metric tons) & 114.7 & 108.5 & 112.0 & 113.8 & 164.6 & 172.9 & 181.1 & 185.2 \\
\hline Curtent account (dcficil= -) & -12.8 & -14.3 & -13.2 & -14.0 & -10.4 & -9.5 & -8.7 & -8.6 \\
\hline Excluding cursent official transfers & -16.0 & -17.4 & -16.8 & -17.7 & -14.6 & -13.4 & -12.6 & $-12,4$ \\
\hline Overall balance (deficit= -) & -0.9 & -2.6 & -1.0 & -1.2 & $\cdot 0.4$ & 0.7 & -0.5 & -0.9 \\
\hline Financing gap & 0.0 & 0.0 & 0.0 & 0.0 & 0.1 & 0.3 & 0.5 & 0.6 \\
\hline Total debt-service ratio $4 /$ & 23,6 & 31.1 & 27.8 & 26.4 & 25.2 & 22.7 & 22.4 & 20.4 \\
\hline [nebr-service ratio (ratio to government revenue) & 17.1 & 23.7 & 20,9 & 20.7 & 20.0 & 17.9 & 17.8 & 16.0 \\
\hline Gress international reserves (in billions of CFA francs) & 192.2 & 171.3 & & 178.4 & 198.7 & 232,9 & 247.2 & 256.7 \\
\hline In months of imports of gaods c.i.f. & 5.5 & 4.8 & & 4.5 & 5.2 & 5.9 & 6.9 & 5.9 \\
\hline In months of imports of goods and nonfactor services & 5.1 & 4.4 & & 4.2 & 4.8 & 5.5 & 5.6 & 5.5 \\
\hline GDP at current prices (in billions of CFAF) & 1,518 & 1,561 & 1,714 & 1,719 & 1,837 & 1,959 & 2,088 & 2,226 \\
\hline
\end{tabular}

Sources: Cenrral Bunk of West Africun Statts (BCEAO); and stuff estimates and projections.

If Based on latest World Economic Outlook (W'EO) projections.

$2 /$ lncludes portfolio inwescment and foreign direet investrmust.

3 Contentious debt in negaliation with non-Paris Club creditors.

4/ In percent of experns of gouts and nonfactor services. 


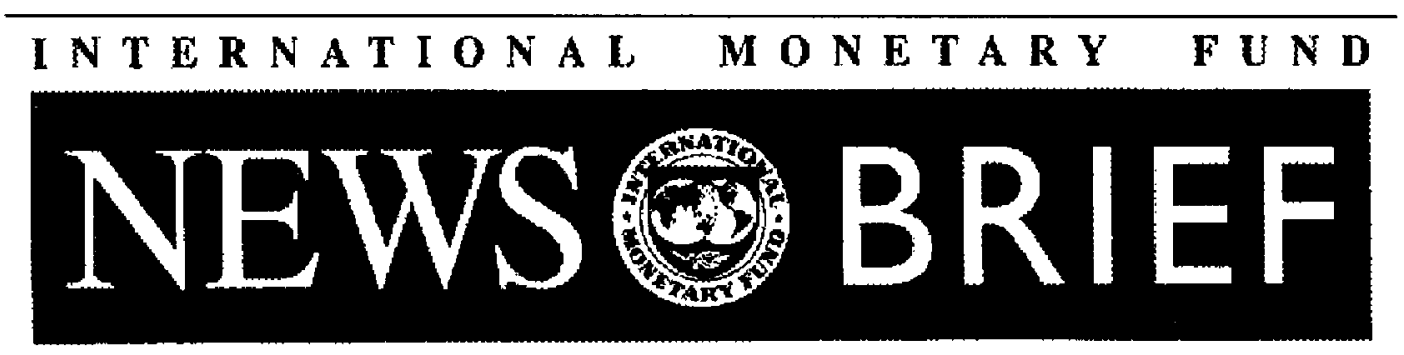

FOR IMMEDIATE RELEASE

News Brief No. 01/123

FOR IMMEDIATE RELEASE

November 30,2001
International Monetary Fund

70019 th Street, NW

Washington, D. C. 20431 USA

\section{IMF Completes In Principle Review Under Burkina Faso's PRGF Arrangement and Approves U\$\$7 Million Disbursement}

The Executive Board of the International Monetary Fund (IMF) today completed in principle the fourth review of Burkina Faso's performance under the program supported by the Poverty Reduction and Growth Facility (PRGF) ${ }^{1}$ Arrangement. As a result, Burkina Faso will in principle be able to draw up to SDR 5.59 million (about US\$7 million).

A final decision by the IMF Executive Board is pending discussion of Burkina Faso's Poverty Reduction Strategy Paper progress report by the World Bank Executive Board, which is scheduled for December 6, 2001.

1 On November 22, 1999, the IMF's concessional facility for low income countries, the Enhanced Structural Adjustment Facility (ESAF), was renamed Poverty Reduction and Growth Facility (PRGF), and its purposes were redefined. It is intended that PRGF-supported programs will in time be based on countryowned poverty reduction strategies adopted in a participatory process involving civil society and development partners and articulated in a Poverty Reduction Strategy Paper (PRSP). This is intended to ensure that each PRGF-supported program is consistent with a comprehensive framework for macroeconomic, structural, and social policies to foster growth and reduce poverty. Burkina Faso completed its Poverty Reduction Strategy Paper in Spring 2000. This resulted from a broad participatory process, which led to the elaboration of a comprehensive long-term strategy with prioritized action plan for the period 200103. PRGF Ioans carry an annual interest of 0.5 percent, and are repayable over 10 years with a $51 / 2$ year grace period on principal payments. 
Burkina Faso's program was originally supported by a three-year arrangement under the Enhanced Structural Adjustment Facility (ESAF) approved on September 10, 1999 (see Press Release 99/42), for SDR 39.12 million (about US\$50 million). So far, Burkina Faso has drawn SDR 22.36 million (about US\$28 million) under the arrangement.

After the Executive Board's discussion on Burkina Faso, Anne Krueger, First Deputy Managing Director and Acting Chairman, stated:

"The PRGF-supported program remains on track despite an economic downturn in 2000, which trailed into the first half of 2001. All end-June and end-September 2001 performance criteria and benchmarks were observed. The authorities have maintained a prudent fiscal policy in the face of a revenue shortfall. To achieve the programmed year-end revenue and budget deficit targets, they have reduced expenditure while protecting social outlays, and have raised taxes on petroleum products. Structural reforms focus on improving the performance of the cotton sector, pushing ahead with the privatization program, and strengthening public finance management, the judicial system, and governance.

"An expected bumper cotton crop should boost growth this year and next, and help alleviate rural poverty. The authorities remain committed to fiscal consolidation, structural reform, and the fight against poverty. Ongoing efforts to broaden the tax base, improve tax administration, and limit lowpriority spending remain critical to mobilize resources for urgent social purposes. Furthermore, the authorities need to adopt a cautious cotton pricing policy in 2002 in the face of a decline in international cotton prices.

"The authorities have vigorously pursued the poverty reduction objectives set out in the PRSP. They have prepared a progress report on the firstyear implementation of the PRSP on the basis of extensive consultations with civil society and development partners. The Fund's Executive Board has deemed the report to be an adequate basis for continuing Fund concessional assistance to Burkina Faso. Progress in social outcomes has been satisfactory, and the authorities intend to steadfastly pursue their ambitious objectives. In particular, they intend to improve the planning, execution, and tracking of the poverty reduction strategy, notably by accelerating the commitment of available resources and energizing the monitoring unit in charge of tracking poverty-related outcomes.

"The authorities have met all the policy reform measures of the floating completion point conditions under the enhanced HIPC Initiative. However, in view of a substantial drop in Burkina Faso's exports and the possible 
case for additional assistance at completion point, Directors supported Burkina Faso's decision to postpone its request for consideration of the completion point document under the enhanced HIPC Initiative to March 2002," Ms. Krueger said. 


\section{N T E R N T I ONALMONETARY FUND}

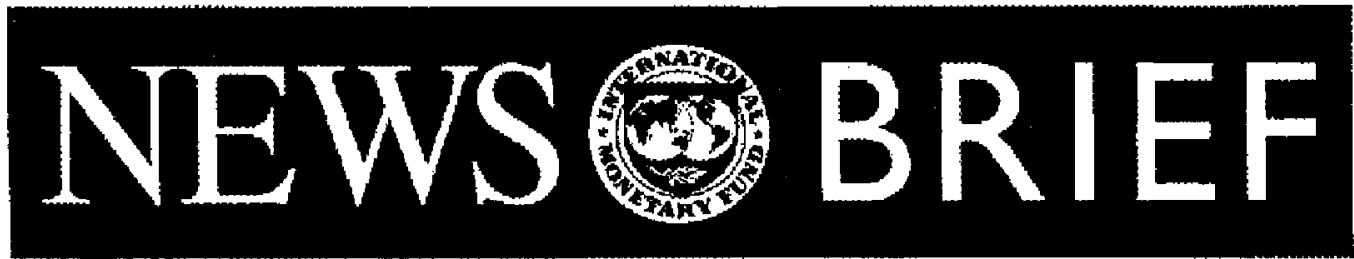

FOR IMMEDIATE RELEASE

News Brief No. 01/128

FOR IMMEDIATE RELEASE

December 10, 2001
International Monetary Fund

700 19th Street, NW

Washington, D. C. 20431 USA

\section{IMF Gives final Approval of Fourth Review Under the PRGF Arrangement for Burkina Faso}

The Executive Board of the International Monetary Fund (IMF) has given its final approval of the fourth review under the Poverty Reduction and Growth Facility (PRGF) arrangement for Burkina Faso.

The final decision by the IMF Executive Board was adopted further to a decision by the Executive Board of the World Bank on December 6, 2001, which concluded that Burkina Faso's Poverty Reduction Strategy Paper progress report provides a sound basis for World Bank concessional assistance.

The completion of the fourth review releases immediately a disbursement of an amount equivalent to SDR 5.59 million (about US\$7 million) under the PRGF arrangement (see News Brief No. 01/123). 